\title{
United Arab Emirates: 2009 Article IV Consultation-Staff Report; Public Information Notice; and Statement by the Executive Director for United Arab Emirates
}

The following documents have been released and are included in this package:

- $\quad$ The staff report, prepared by a staff team of the IMF, following discussions that ended on January 13, 2010, with the officials of United Arab Emirates on economic developments and policies. Based on information available at the time of these discussions, the staff report was completed on February 3, 2010. The views expressed in the staff report are those of the staff team and do not necessarily reflect the views of the Executive Board of the IMF.

- $\quad$ A Public Information Notice (PIN).

- $\quad$ A statement by the Executive Director for United Arab Emirates.

The policy of publication of staff reports and other documents allows for the deletion of market-sensitive information.

\author{
Copies of this report are available to the public from \\ International Monetary Fund • Publication Services \\ $70019^{\text {th }}$ Street, N.W. • Washington, D.C. 20431 \\ Telephone: (202) 623-7430 • Telefax: (202) 623-7201 \\ E-mail: publications@imf.org Internet: http://www.imf.org
}

\section{International Monetary Fund Washington, D.C.}




\title{
INTERNATIONAL MONETARY FUND
}

\section{UNITED ARAB EMIRATES}

\section{Staff Report for the 2009 Article IV Consultation}

\author{
Prepared by the Staff Representatives for the 2009 Consultation with \\ the United Arab Emirates
}

Approved by Juan Carlos Di Tata and David Marston

January 22,2010

Mission dates: October 13-28, 2009 and January 3-11, 2010 in Abu Dhabi and Dubai, and January 12-13, 2010 in London.

Team: Mr. Leon (Head), Messrs. Cevik, Espinoza, Ribeiro da Silva, Sensenbrenner, and Williams (all MCD), Mr. Blitzer and Ms. Raei (MCM), and Ms. Liu and Mr. Bergthaler (LEG). Messrs. Ahmed and Di Tata (MCD) participated in the policy discussions.

Meetings: The team met with the Minister of State for Financial Affairs, the Governor of the Central Bank, the Head of the Dubai Fiscal Supreme Committee, senior officials of the federal and emirate governments, top executives at the Dubai Ruler's Court and governmentrelated corporations, and representatives of commercial banks, law firms, and business communities in the United Arab Emirates (U.A.E.) and London.

Exchange arrangement: The U.A.E. has accepted the obligations of Article VIII, Sections 2, 3, and 4. There are no restrictions on payments and transfers for current international transactions. Since 2002 , the dirham has been officially pegged to the U.S. dollar.

Data: Broadly adequate for surveillance; substantial shortcomings at the emirate level and for government-related corporations.

Past surveillance: The authorities and Fund staff have generally agreed on broad policy priorities. The 2008 Article IV consultation (concluded on January 9, 2009) is available at http://www.imf.org/external/pubs/cat/longres.cfm?sk=22880.0 (Country Report No. 09/124). 


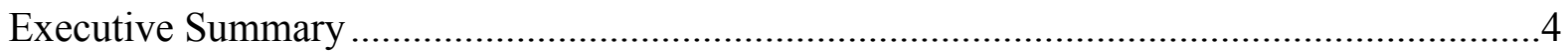

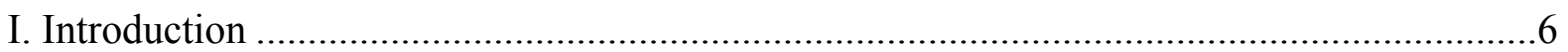

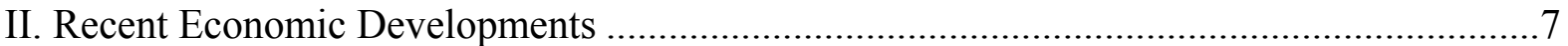

A. Dubai Contracts and Abu Dhabi Expands .............................................................

B. The Dubai World Debt Situation and Ramifications ................................................

C. The Outlook for 2010 and the Medium Term .........................................................13

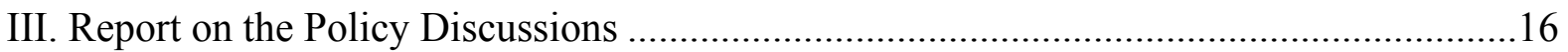

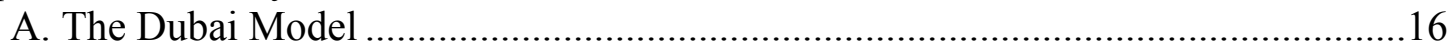

B. Policy Mix on the Exit Path from the Crisis ........................................................16

C. Dubai's Debt Restructuring and Potential Spillovers .............................................17

D. Financial System Stress Analysis ……………………....................................20

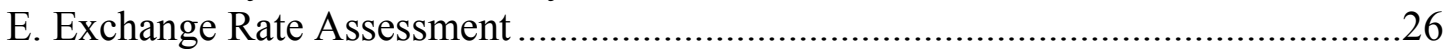

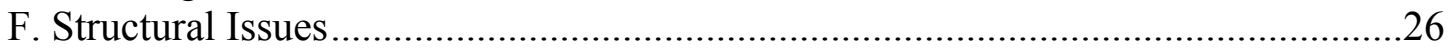

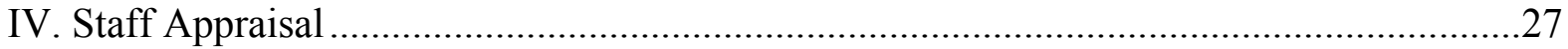

Text Tables

1. Cross-Country Perspective on Wealth and Reserve Adequacy, 2009 or latest.....................6

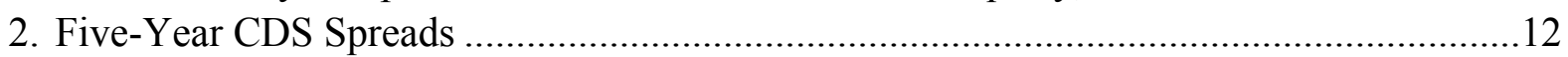

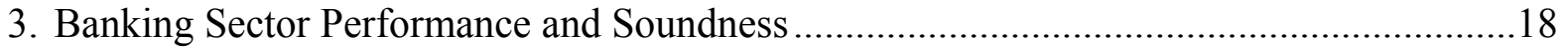

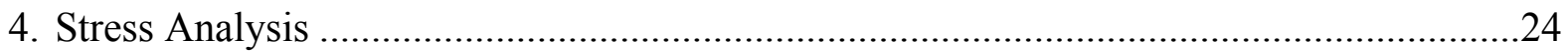

Boxes

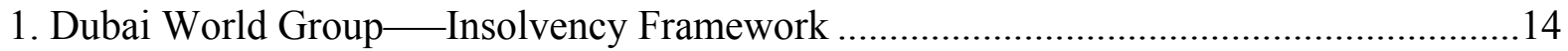

2. Considerations on Restructuring of State-Owned Entities ...................................................19

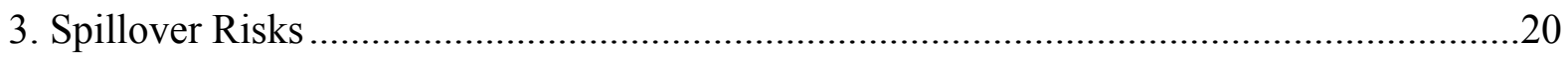

4. Methodology and Calibration of Stress Test ………......................................................23

Figures

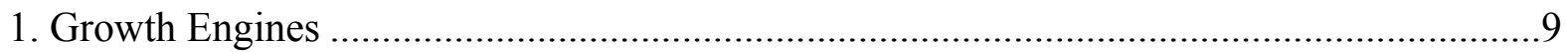

2. Macroeconomic Impact of Global Financial Crisis ........................................................10

3. Dubai Property Bubble .................................................................................................1

4. The Over-Extended Financial Sector Receives Strong Support .........................................21

5. Current Account Norms vs. Actual and Projected Current Account

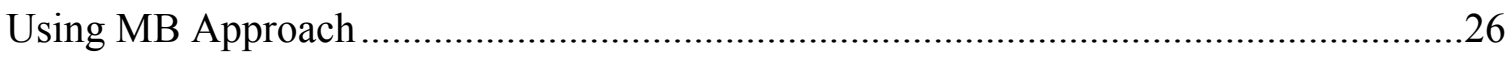

6. Current Account Norms vs. Projected Current Account Under Constant

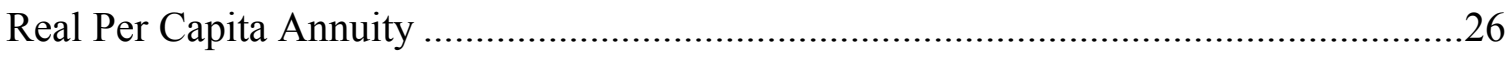


Tables

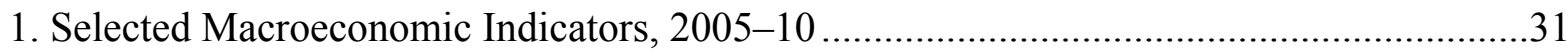

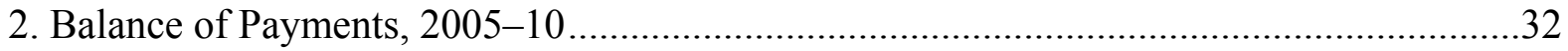

3. Consolidated Government Finances, 2005-10 .............................................................33

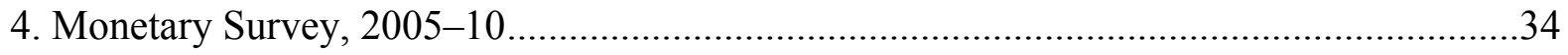

5. Medium-Term Baseline Scenario, 2010-15 ...............................................................35

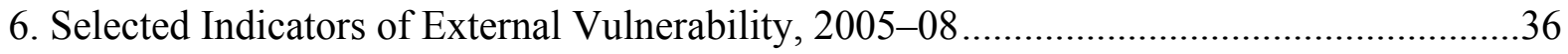

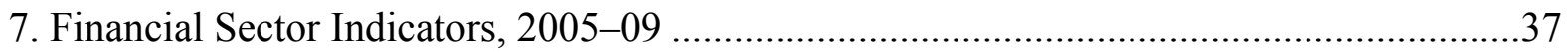

Annex

The U.A.E. Federation and the Dubai Debt Situation .........................................................37

Attachment

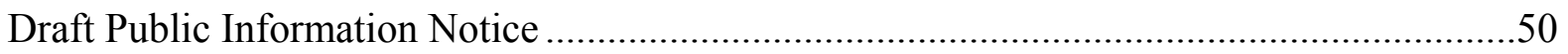




\section{EXECUTIVE SUMMARY}

In 2009, the U.A.E. witnessed a significant slowdown in growth and strains in the banking system as a result of the global financial crisis, the decline in oil prices, and the continuing fallout from the bursting of the Dubai property bubble. The announcement in late November that Dubai World (DW) would seek a standstill and the restructuring of part of its debt started another round of ripple effects. The ramifications of the DW debt event will depend on the scope and modalities of the debt restructuring, its impact on the financial sector, and the strategy being developed by the Government of Dubai (GD) to put DW and possibly other corporate entities on a viable economic and financial footing. Improved global conditions, especially out of Asia, will fuel Dubai's logistics and service sector. However, the correction in the over-extended property and construction sector renders the overall outlook highly uncertain. With foreign investor confidence shaken and international capital markets less accessible, Abu Dhabi's policy of selective support to Dubai will play an important role in limiting contagion to the U.A.E. economy and the banking system.

\section{The authorities}

- $\quad$ Responded to the global financial crisis in a comprehensive and prompt manner, maintaining confidence in the banking system through various emergency liquidity facilities, the guarantee of deposits, and measures to strengthen the banking sector;

- Increased spending on strategic infrastructure projects, mainly in Abu Dhabi, to reduce the contraction in construction activity, and provided support to quasi-public entities and national banks;

- $\quad$ After the debt announcement in November, reiterated that the debt of DW was not guaranteed by the GD, announced that a corporate restructuring was being designed in conjunction with the debt restructuring of part of DW liabilities, and initiated insolvency law reform; and

- Increased efforts to build statistical capacity.

\section{Staff recommendations}

At the Dubai level

- $\quad$ For the debts of DW subject to restructuring, ensure a speedy, orderly, and transparent process utilizing "best practices" for engaging creditors. The objective should be to balance the viability (without government support) of these entities with the need to limit contagion to the economy and the banking sector; 
- $\quad$ Communicate clearly on the viability of Dubai entities and the modalities of support (including from Abu Dhabi). This is important to credibly signal which borrowings are purely commercial and which are essentially governmental;

- Increase transparency of economic and financial data, including financial accounts and business strategies for government-related enterprises (GREs). Together with improved corporate governance, these steps would contribute to rebuilding reputation and creditworthiness and facilitate access of viable GREs to capital markets.

At the broader U.A.E. level

- $\quad$ Articulate a contingency plan for the banking system to deal with the potential deterioration in asset quality;

- Design macroprudential tools to avert a resurgence of imbalances and discourage a return of speculative behavior in the property sector;

- $\quad$ Promote counter-cyclical bank solvency and liquidity buffers, with special attention to systemically-important banks;

- $\quad$ Coordinate the fiscal policies of the key emirates' and federal governments;

- $\quad$ Centralize debt management at the federal level to minimize risks, while allowing emirate-level debt management offices to increase coordination of debt issuance by their GREs;

- $\quad$ Evaluate the medium-term fiscal implications of the scaling up in infrastructure spending and the socioeconomic implications of the growing participation of skilled foreigners in the labor force;

- $\quad$ Put in place an appropriate corporate insolvency regime at the federal level to provide a transparent framework for debt resolution; and

- $\quad$ Continue efforts to develop statistical capacity at the federal level, including public sector statistics and the compilation and publication of the International Investment Position (IIP). 


\section{INTRODUCTION}

1. The 2009 Article IV consultation discussions with the U.A.E. took place against the backdrop of the global financial crisis and the announcement by DW in late November that it would seek a standstill on some of its outstanding debt. After years of robust growth, the U.A.E. economy appeared vulnerable. Signs of a slowdown were already emerging in Dubai from the bursting of the property bubble in 2008. Abu Dhabi, with huge oil reserves and very large external assets, borrowed to supplement its revenues and increased expenditure significantly to maintain non-oil activity. However, the combination of substantial short-term borrowing, a collapse of the local property market, and maturity mismatches ultimately forced DW to seek a debt standstill as a prelude to a restructuring of its debts.

\section{The crisis unfolded with differential impact on Abu Dhabi and Dubai. It} highlighted three key issues: (i) the contrast between growth based on hydrocarbon resources and that based on nonhydrocarbon diversification funded by maturity-mismatched leverage; (ii) the spillover effects and financial support structures in the federation; and (iii) the volatility of markets in response to a lack of information disclosure and transparency. In particular, the debt announcement undermined the widely held market perception of implicit government support, including from Abu Dhabi.

3. However, recent developments in Dubai, while material, should be viewed in the wider perspective of the U.A.E. as a whole. Although the need to roll over part of Dubai's substantial external borrowing in the post-Lehman environment has highlighted the risk embedded in the financing strategy of some Dubai entities, the U.A.E. has a net external creditor position well in excess of 100 percent of GDP, among the largest in the Fund's membership (Text Table 1). This position is overwhelmingly with Abu Dhabi, especially as concerns liquid unencumbered external assets, but several of Dubai's GREs also have accumulated substantial assets abroad (Annex).

Text Table 1. Cross-Country Perspective on Wealth and Reserve Adequacy, 2008 or Latest

\begin{tabular}{|c|c|c|c|c|c|}
\hline & Norway & Singapore & Australia & Bahrain & U.A.E. \\
\hline & \multicolumn{5}{|c|}{ (In billions of U.S. dollars, unless otherwise indicated) } \\
\hline Central bank reserves & 45 & 176 & 40 & 4 & 30 \\
\hline IIP assets $1 /$ & 920 & 941 & 702 & 217 & 437 \\
\hline IIP liabilities 1/ & 682 & 749 & 1196 & 202 & 132 \\
\hline Net assets & 238 & 192 & -494 & 15 & 305 \\
\hline GDP & 455 & 183 & 985 & 18 & 230 \\
\hline Nationals (in millions) & 4.8 & 4.6 & 21.0 & 0.5 & 1.2 \\
\hline Net assets/GDP & $52 \%$ & $105 \%$ & $-50 \%$ & $83 \%$ & $132 \%$ \\
\hline Of which: net assets of central bank & $10 \%$ & $96 \%$ & $4 \%$ & $22 \%$ & $13 \%$ \\
\hline Net assets per national (in U.S. dollars) 2/ & 50,000 & 40,000 & $-20,000$ & 30,000 & 250,000 \\
\hline
\end{tabular}




\section{RECENT ECONOMIC DEVELOPMENTS}

\section{A. Dubai Contracts and Abu Dhabi Expands}

4. The global recession, the bursting of the Dubai property bubble, and the postLehman shutdown of international capital markets hit simultaneously all of the U.A.E.'s three growth engines in 2009. Oil receipts plummeted, global trade and logistics contracted, and property development all but ground to a halt as incomes fell and property prices plunged. A second bout of disruption arose when the government of Dubai announced in late November 2009 that DW would seek a six-month standstill on repayments while some \$26 billion in debt was restructured. After three weeks of increasing tensions with creditors, DW paid off the Nakheel bond on time, settling market nerves.

5. The authorities responded decisively to contain strains in the banking system and sustain economic activity. Abu Dhabi boosted the fiscal stance via equity injections and loans to its GREs. The central bank deployed bank liquidity support facilities and lowered interest rates. The federal government rolled out large scale recapitalization measures and provided AED 50 billion term funding to the banks. Finally, the GD announced a support package of $\$ 20$ billion (half provided by the central bank and the other half by Abu Dhabi) to finance the needs of Dubai's GREs, and established the Dubai Financial Support Fund (DFSF) to manage the support program.

6. Notwithstanding the compensatory measures adopted by the authorities, overall real GDP is estimated to have contracted by about $1 / 2$ percent in 2009 . After years of high oil prices and production at full capacity, crude oil production averaged only 2.4 million barrels per day in 2009, with hydrocarbon GDP declining by $6 \frac{1}{4}$ percent. At the same time, nonhydrocarbon growth, which had averaged 8 percent in the three previous years, is estimated to have slowed to about 1 percent. This figure masks the diverging fortunes of Abu Dhabi, where growth was sustained by public sector investment spending, and the northern emirates (in particular Dubai and Sharjah), where economic activity fell owing to the bursting of the property bubble ${ }^{1}$ and the contraction in world trade. ${ }^{2}$

\section{After peaking at about 12 percent in 2008, inflation declined to 1 percent in} 2009, reflecting lower import prices (-10 percent in 2009) and a reduction in rents ${ }^{3}$ as an increased share of rental contracts got renewed at the deflated market prices and new buildings came on stream.

\footnotetext{
${ }^{1}$ Dubai Land Department statistics show that residential prices fell by more than 50 percent between September 2008 and September 2009. There are no official data on commercial real estate prices.

${ }^{2}$ Overall, the 1 percentage point growth headline for non-oil real GDP for the U.A.E. as a whole is a weighted average of 60 percent of Dubai and the northern emirates' negative growth ( -1 percent) and 40 percent of Abu Dhabi's strong positive growth (6 percent).

${ }^{3}$ Rents, which represent almost 40 percent of the CPI basket, had fallen by 10 percent (y-o-y) in December 2009. Over the medium term, CPI inflation is projected from import prices and the nontradable GDP deflator.
} 
8. The external current account balance is estimated to have shifted to a deficit of 2.7 percent of GDP in 2009, the first deficit in decades. As a result of OPEC-mandated production cuts and lower prices, hydrocarbon export revenues dropped by about 45 percent in 2009, while imports fell 22 percent owing to a sharp contraction in consumer goods imports and despite the large investment projects supported by the government of Abu Dhabi.

9. The reopening of capital markets in the second quarter of 2009 helped stabilize financial account flows. The post-Lehman shut down of international capital markets and the reversal of capital flows relating to speculation about a dirham appreciation, led to a large deficit (\$55 billion) in the financial account in 2008, resulting in a substantial drop in central bank international reserves to $\$ 31$ billion by year's end. However, new external borrowing, mainly by Abu Dhabi entities, helped stabilize the reserves by the end of 2009 .

10. Broad money growth slowed from 19 percent in 2008 to 10 percent in 2009. Credit to the private sector was broadly flat in 2009 as demand weakened and commercial banks adopted a much more cautious approach in response to the riskier environment. Credit was therefore redirected towards public sector enterprises (35 percent growth in 2009), and banks reconstituted their liquidity in the form of certificates of deposits (CDs) at the central bank.

11. The consolidated fiscal position is estimated at a virtual balance in 2009 , following a surplus of 21 percent of GDP in 2008. Both oil and non-oil revenues fell owing to the decline in oil prices and the slowdown in economic activity. At the same time, total spending is estimated to have increased by 14 percent - a continuation of the expansionary fiscal stance adopted in 2008 — with capital outlays rising by about 20 percent. The nonhydrocarbon deficit widened by about 7 percentage points to 34 percent of non-oil GDP owing mainly to higher spending by the government of Abu Dhabi, which provided substantial equity and loan (6 $1 / 4$ percent of GDP) to strategic Abu Dhabi GREs involved in large projects. Dubai's fiscal stance was mildly expansionary, reflecting the implementation of large infrastructure projects (metro, airport, and roads).

\section{B. The Dubai World Debt Situation and Ramifications}

12. Dubai's economy is dominated by Dubai Inc., a web of commercial corporations, financial institutions, and investment arms owned directly by the GD or the ruling family under the umbrella of three major holding companies (Dubai Holding (DH), DW, and the Investment Corporation of Dubai (ICD)). Each holding company includes several property developers and is involved in assorted property ventures in Dubai and around the world. Dubai Inc. entities borrowed extensively in 2004-08 to fund a major push into largescale commercial and residential property development. A significant increase in leverage ensued, followed by a real estate price bubble. Since much of the debt had relatively short maturities, and cash flows from property development would fully accrue with a longer horizon, the risk from the maturity mismatch was always present; the collapse of local property markets (due largely to a capacity glut in commercial and residential property) and the global crisis highlighted these risks and accelerated the timing of their realization. 
Figure 1. United Arab Emirates: Growth Engines

U.A.E. has abundant hydrocarbon wealth, both above and below ground.

300

Oil\&gas reserves/national ( $\$$ million at $\$ 100 / \mathrm{bbl})$

$\square$ GDP per capita (\$ thousands)

$\square$ Above-Ground Wealth per national 200

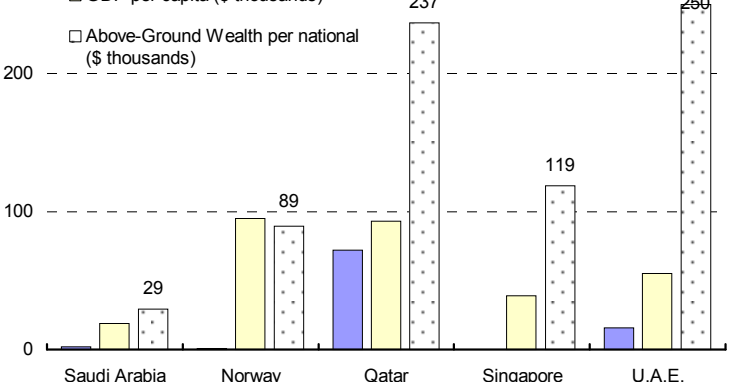

...though fiscal policy remains reliant on oil revenue from Abu Dhabi which has 95 percent of reserves.

U.A.E. Consolidated Budget: Expenditure Shares, 2007

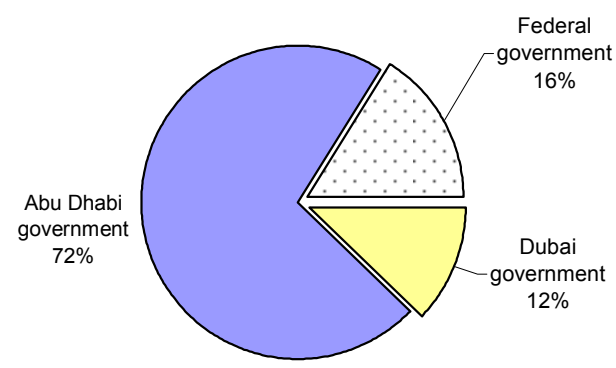

Dubai growth engines: Singapore-type diversification into global trade and services, particularly South Asia and the wider GCC region...

Non-oil Exports by Destination, 2008, in percent

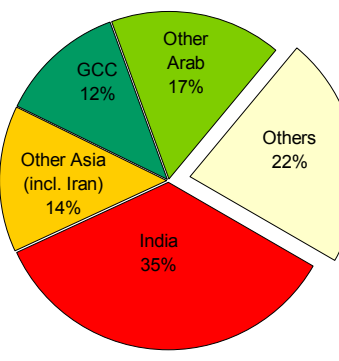

U.A.E. Re-exports by Destination, 2008, in percent

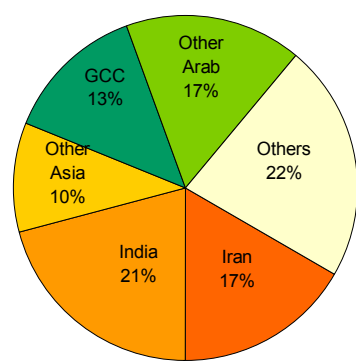

New growth engines have supplemented oil over the past few years..

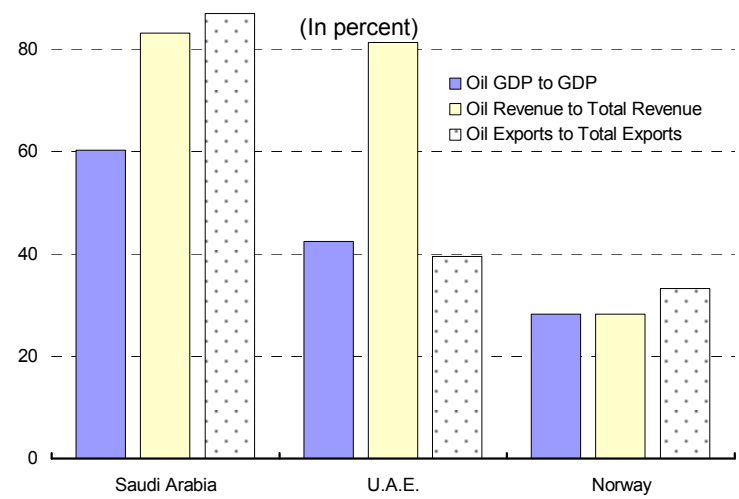

The emirate of Dubai has led the diversification effort away from hydrocarbons.

Emirates' shares in non-oil GDP

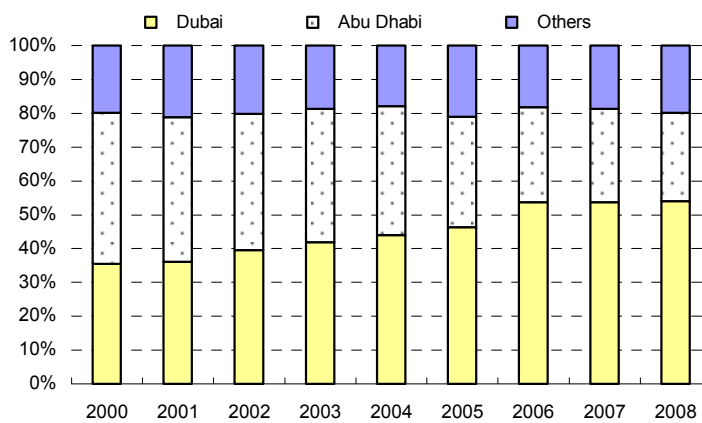

...more recently, strong push into property and hospitality.

Awarded/Completed Major Projects $\%$ of GDP

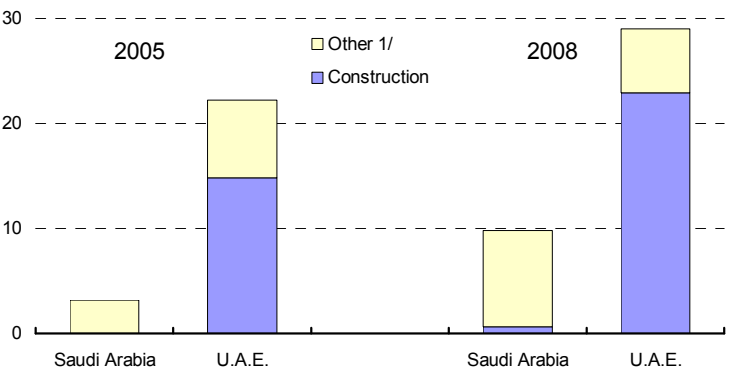

Sources: BP; WEO; World Bank; MEED Projects Database; country authorities; and Fund staff calculations.

$1 /$ Other $=$ Infrastructure, industrial, oil \& gas, power, petrochemical, waste \& water 
Figure 2. United Arab Emirates: Macroeconomic Impact of Global Financial Crisis

The oil engine (Abu Dhabi) and non-oil engines (Dubai) stall at the same time.

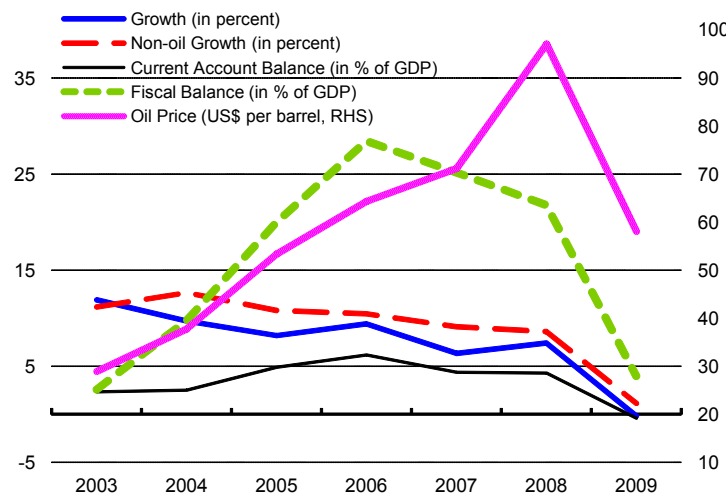

Interbank market tightened before Lehman (reversal of 2007 speculative inflows); rates have since struggled to come down (risk aversion).

Interbank Rates, Jan. 1, 2007-Jan. 14, 2010 (In percent per annum)

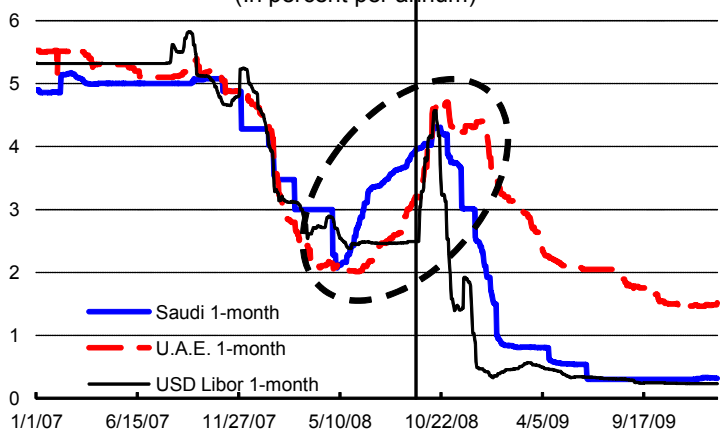

Global banks resumed lending at height of CDS turmoil in 2009 Q1,

Global banks' lending to U.A.E. and Singapore (U.S. dollar billions)

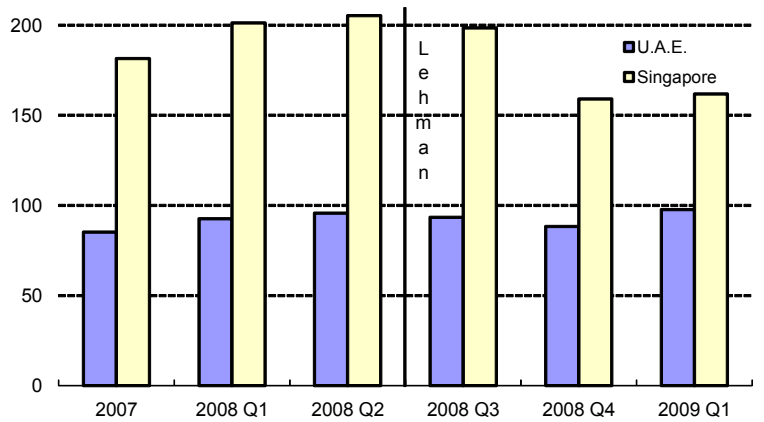

Sharp slowdown in inflation and monetary aggregates.

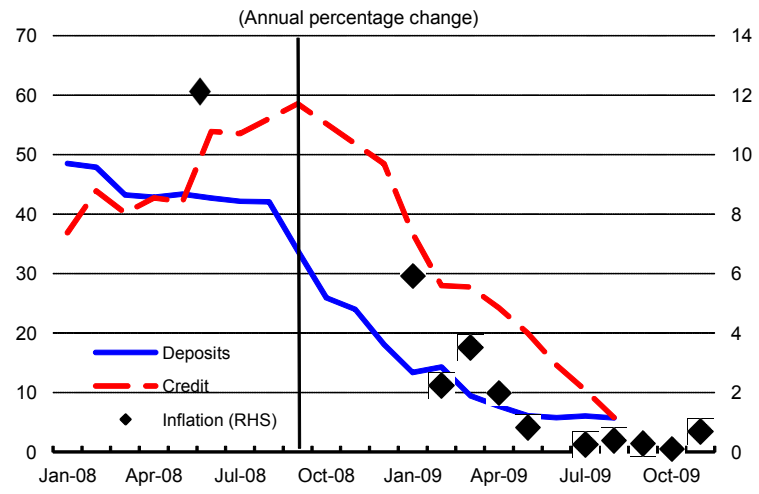

Credit markets differentiate among emirates, yet contamination from Dubai pushes Abu Dhabi credit insurance higher (compared to Singapore).

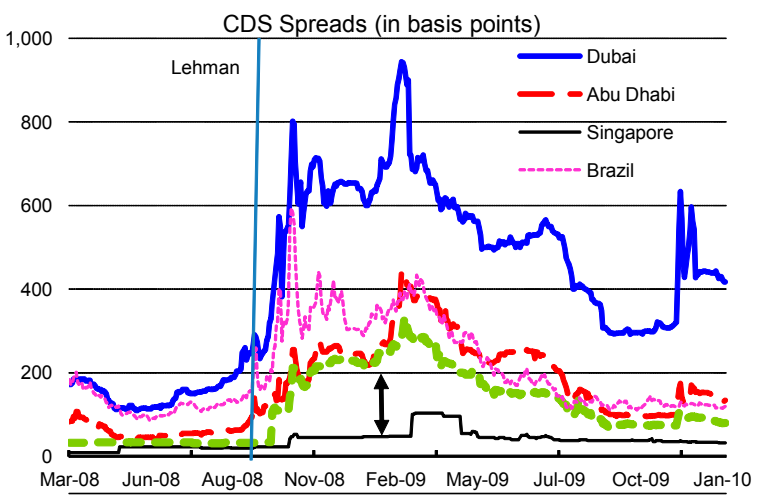

...but differentiation: capital markets shut Dubai out, while Abu Dhabi increases access.

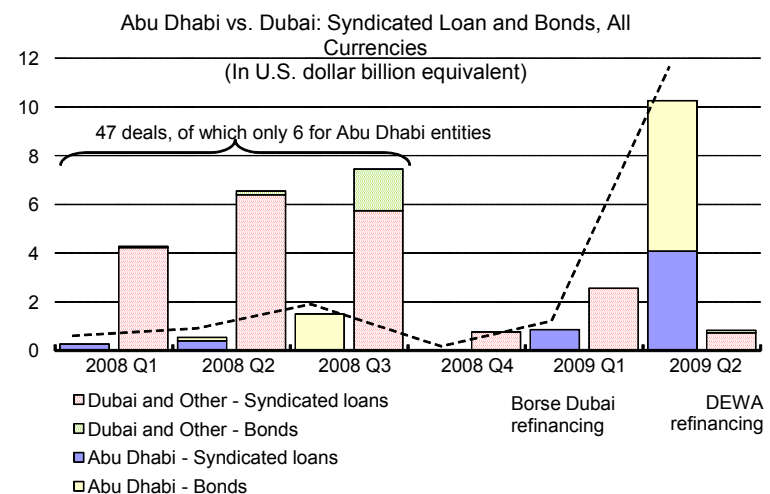

Sources: Bloomberg; Haver; Markit; Dealogic; BIS; country authorities; and Fund staff calculations. 
Figure 3. United Arab Emirates: Dubai Property Bubble

Push into property/hospitality was financed by external borrowing/leverage...

Ratio: liabilities to BIS banks/non-oil GDP (Index, 2005Q2 = 100)

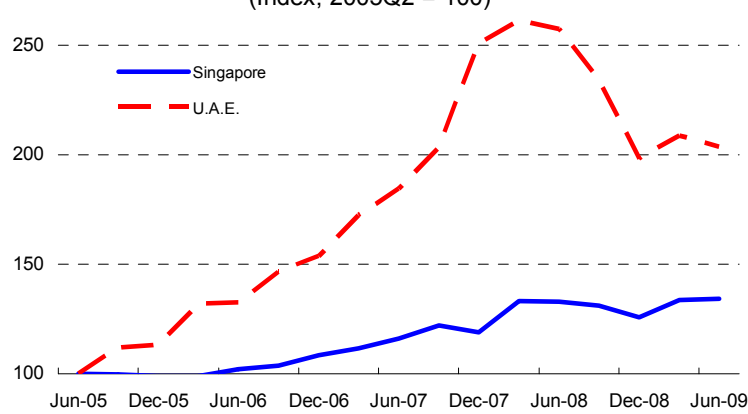

U.A.E. borrowers cut their cover ratio to the level of Singapore in recent years...

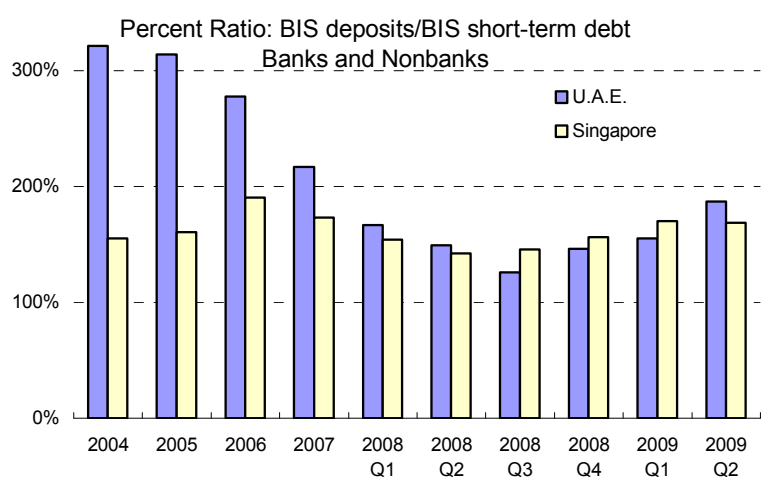

Property transactions started to decline before Lehman .

Dubai Real Estate Sales

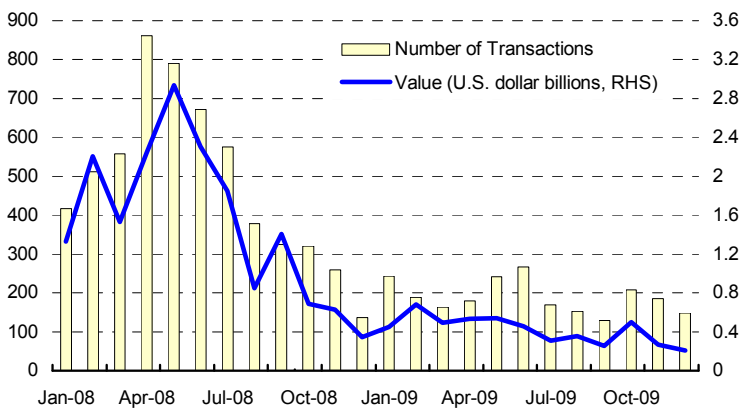

... as well as local borrowing, with a marked domestic credit bubble since 2004.

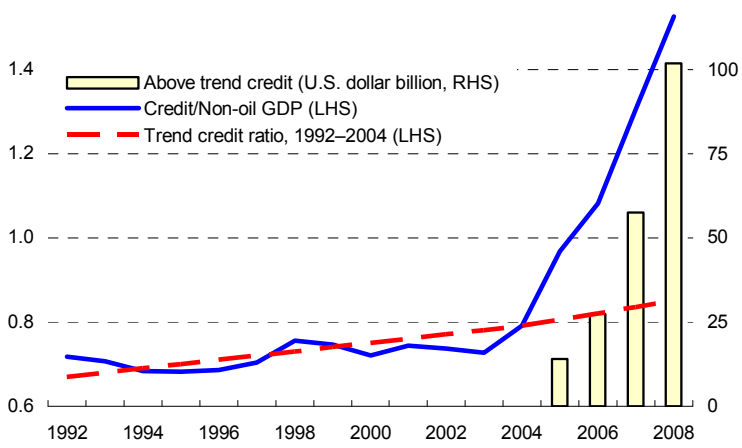

... though U.A.E. corporates went much beyond that, resulting in inordinate rollover risk.

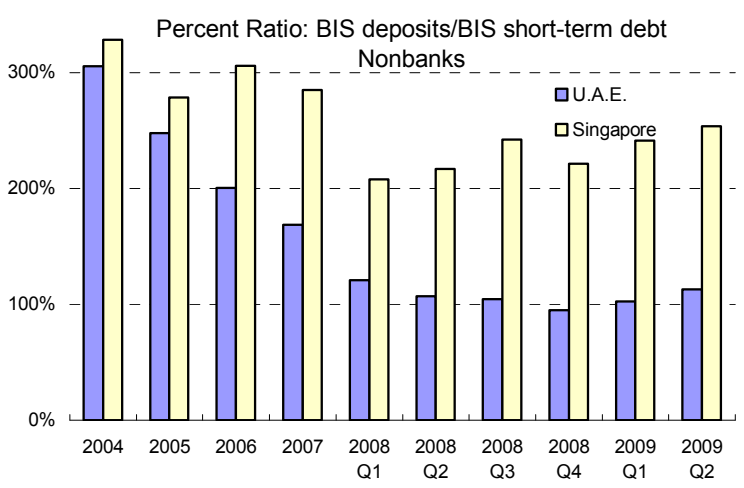

The price drop was as dramatic as the earlier increase, erasing all gains since 2006. Urban Real Estate Prices, CPI-deflated (index, Q12007 $=100$ )

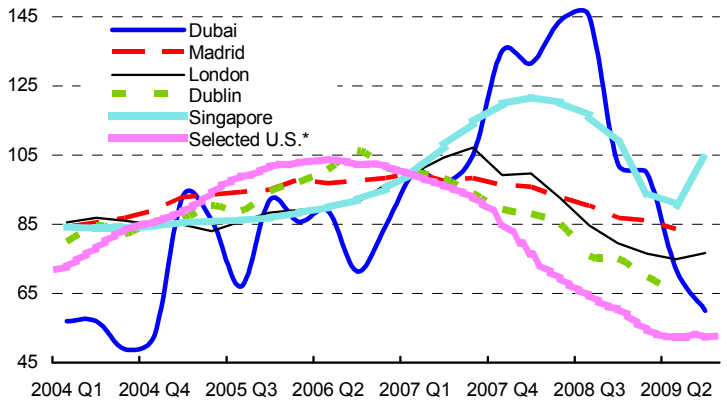

Sources: BIS; WEO; Dubai Land Department; Haver; Min. de Viviendas; *Case/Shiller (San Francisco, Los Angeles, San Diego, Miami, Tampa, Vegas, Phoenix); and Fund staff calculations.

\section{On November 25, 2009, the GD announced that DW and its two property} development subsidiaries (Nakheel Properties and Limitless World) would seek a standstill on property-related debt until May 2010 to allow time for an orderly restructuring. The standstill and restructuring was to affect $\$ 26$ billion worth of bilateral bank loans, syndicated loans, and bonds, including a Nakheel sukuk due to mature on December 14 and guaranteed by DW. 
14. The November announcement came as a surprise to markets. The bursting of Dubai's real estate bubble in 2008, coupled with the global recession and financial market crisis, had heightened investors' concerns about Dubai's ability to service its debt, particularly in the case of highly-leveraged real estate enterprises. But in the several months leading to November 25, Dubai entities had been able to roll over market debt falling due, the GD had successfully issued a large sukuk, the value of Nakheel bonds had increased to above par after trading at about 60 during the spring, and credit default swaps (CDS) spreads on U.A.E. entities had tightened considerably.

\section{The announcement had a pronounced impact on Dubai's perceived credit risk as market participants could no longer assume an implicit sovereign guarantee} (Text Table 2). The Nakheel bond due in December traded down to about 50 cents, from 111 on November 23; CDS spreads on the GD rose sharply; and Dubai GREs were downgraded by several notches, most to noninvestment grade. At the same time, stock markets in Dubai and Abu Dhabi dropped significantly; those in the rest of the GCC experienced higher volatility, and other countries' CDS spreads widened marginally in the week after the announcement. Although CDS spreads have declined since the repayment of the Nakheel sukuk on December 14, they remain elevated for Dubai issuers.

Text Table 2. Five-Year CDS Spreads (bps)

\begin{tabular}{|c|c|c|c|c|}
\hline & $\begin{array}{l}\text { Monday } \\
\text { 23-Nov 1/ }\end{array}$ & $\begin{array}{l}\text { Friday } \\
\text { 27-Nov 2/ }\end{array}$ & $\begin{array}{l}\text { Monday } \\
\text { 14-Dec 3/ }\end{array}$ & $\begin{array}{c}\text { Monday } \\
\text { 18-Jan }\end{array}$ \\
\hline \multicolumn{5}{|l|}{ U.A.E. } \\
\hline Dubai Holding & 670 & 1450 & 1599 & 1355 \\
\hline Government of Dubai & 317 & 675 & 428 & 427 \\
\hline DP World & 355 & 740 & 454 & 412 \\
\hline Government of Abu Dhabi & 100 & 183 & 153 & 136 \\
\hline \multicolumn{5}{|l|}{ Other GCC Countries } \\
\hline Bahrain & 175 & 260 & 209 & 178 \\
\hline Qatar & 74 & 107 & 95 & 87 \\
\hline Saudi Arabia & 94 & 110 & 99 & 78 \\
\hline \multicolumn{5}{|l|}{ Other Economies } \\
\hline Turkey & 194 & 224 & 195 & 169 \\
\hline Russia & 191 & 220 & 192 & 169 \\
\hline Egypt & 221 & 235 & 241 & 242 \\
\hline \multicolumn{5}{|l|}{ Source: Bloomberg } \\
\hline
\end{tabular}

16. Global stock market reactions to the initial announcement were strong but brief, with bank stocks most affected - especially for banks believed to be exposed to DW or other firms with direct links to Dubai. The decline in stock prices also reflected global market fragilities, low liquidity ahead of holidays in the U.S. and the Middle East, and end-of-year effects.

\section{However, Abu Dhabi extended $\mathbf{\$ 1 0}$ billion to the GD to limit contagion to other} parts of the U.A.E.'s economy. \$5 billion was provided through two Abu Dhabi banks and the remainder will be included in Abu Dhabi's 2010 budget. The GD used part of these resources to repay in full the Nakheel 09 and announced that the remainder would be used to cover payments to contractors, working capital, and interest expenses through end-April 2010, conditional on a standstill agreement being reached between DW and its creditors. No amounts for these various categories have yet been announced. 
18. Following the standstill announcement and the potential for litigation, the GD approved a new insolvency regime aimed at facilitating an orderly and efficient restructuring of DW debt (Box 1). The new regime reflects the GD's keenness to preserve the rights of DW creditors and to enhance Dubai's role in the global economy by honoring all contractual commitments with creditors.

19. DW and its creditors are negotiating a standstill agreement. Since mid-December there have been ongoing discussions between DW and its advisors and representatives of more than 90 banks (U.A.E.-based and externally-based) regarding a formal standstill agreement. A group of 7 large banks has formed a steering committee, a structure of engagement consistent with international corporate debt restructuring. Although to date there is no formal agreement, DW is continuing to pay interest on time and banks have been informally rolling over loans. However, there is some urgency for this process - first a standstill agreement, then a restructuring - to move forward since there are some debts that will mature during the proposed standstill period. The restructuring could be affected by the modalities of the treatment of debt owed to suppliers, to banks, and bonded debt.

\section{The Outlook for 2010 and the Medium Term}

20. The fiscal and monetary policy mix will need to show adaptability over the medium term in order to sustain a further diversification of the economy within a more uncertain environment. In this regard, the federation will continue to benefit from its large external creditor position, its excellent infrastructure and business conditions, and its prime location between Europe and Asia.

21. The staff's baseline scenario envisages a further deceleration in non-oil growth in 2010, followed by a gradual recovery thereafter. Dubai's economic activity in 2010 will depend on global demand for Dubai goods and services, whether the property market begins to recover (construction and property-related activity account for 25 percent of Dubai's GDP), and how protracted is the GRE debt restructuring. Given Dubai's share in U.A.E.'s non-oil GDP (above 50 percent) real GDP growth for the U.A.E. as a whole will be low (about $1 / 2$ percent), despite the authorities' support packages and Abu Dhabi's investment projects that will help offset the contraction in Dubai. ${ }^{4}$ Growth would recover starting in 2011 owing to (i) higher activity in the oil and trade sectors in response to the recovery in Asia; and (ii) an orderly restructuring of Dubai's GREs. Medium-term nonhydrocarbon growth is projected to average about $4 \frac{1}{2}$ percent a year over the medium term, or 4 percentage points lower than before the crisis, a reflection of less activity in Dubai's property sector and higher costs to access international capital markets. CPI inflation is expected to reflect higher import prices and the impact of Abu Dhabi's large investments in infrastructure.

\footnotetext{
${ }^{4}$ Projects already under construction are expected to represent $\$ 100$ billion in 2010 (50 percent of NHGDP), and up to $\$ 400$ billion by 2015 (about 25 percent of non-oil GDP over that period).
} 


\section{Box 1. Dubai World Group-Insolvency Framework}

The Ruler of Dubai issued a decree effective December 13, 2009 (the "Decree") to establish a special insolvency regime to facilitate the reorganization and debt restructuring of Dubai World and its subsidiaries. ${ }^{1}$ According to the GD, a special framework was considered necessary to support an orderly and efficient restructuring of these companies mainly for three reasons. First, Dubai World, a company established pursuant to a decree issued by the Ruler of Dubai, is not subject to any insolvency framework in the U.A.E., namely, the federal framework or the Dubai International Financial Centre (DIFC) framework. Second, subjecting Dubai World and its subsidiaries (the "DW Group") that operate under several legal regimes within the U.A.E. to a unified system would minimize the potential of applying different insolvency frameworks. Third, while the DIFC insolvency regime is generally regarded to be broadly consistent with international standards, the federal insolvency framework has been rarely used and may not be suitable for complex multi-creditor insolvency proceedings.

The Decree also establishes a special tribunal ("Tribunal") to adjudicate disputes relating to debt restructuring of the DW Group. The Decree gives the Tribunal the exclusive jurisdiction to decide all claims submitted against the DW Group or any person (e.g., a member of the Board of Directors) relating to the debt restructuring of these companies by applying specified insolvency legislation ${ }^{2}$ as well as "commercial custom, principles of justice, and rules of righteousness and equity." Under the Decree, the Tribunal consists of three internationally recognized judges. ${ }^{3}$ All proceedings will be conducted in English and are open to the public. The Tribunal's decisions, issued by the majority votes of its judges, are final, irrevocable, and not subject to any appeal.

This new insolvency regime for the DW Group is generally viewed by creditors as a welcomed move towards providing a legal backdrop for an orderly approach to debt restructuring. The regime, which is based on the insolvency laws, rules and regulations of the DIFC (which are based on English insolvency law) with some modifications, includes the following key features that could help facilitate debt restructuring while protecting creditors' rights: (i) providing for an automatic moratorium applicable to all creditors upon the filing of a notification by DW or any of its subsidiaries stating its intention to make a proposal to its creditors for a voluntary arrangement; (ii) allowing the Tribunal to cram down dissenting creditors when a voluntary arrangement is approved by two-thirds in value of any class of creditors or equity interest holders; (iii) separately classifying secured creditors, unsecured creditors, and equity interest holders for voting purposes and giving them the right to challenge a voluntary arrangement if they believe the arrangement is unfairly prejudicial to them or wrongly entered into; (iv) according priority repayment status to creditors that are willing to provide new financing during the voluntary arrangement period subject to certain conditions; and (v) permitting the DW Group to assume or reject any contracts or unexpired leases subject to the approval of the Tribunal. However, creditors of the DW Group also expressed the view that the new regime fails to include certain features in line with international best practices such as set-offs and creditors' right to seek relief from a moratorium under certain conditions.

It remains to be seen how the new insolvency framework will be applied and Tribunal decisions be enforced. The limited experience with the DIFC insolvency framework provides little guidance on how the new law will be applied in practice. In addition, it is unclear whether the Tribunal decisions will be recognized and enforced outside the U.A.E., and whether the Tribunal has the power to enforce foreign judgments against the DW Group.

1/ http://www.uaepm.ae/en/media/news/articles/news360.html.

2/ DIFC Law No (3) of 2009 Concerning the Law of Insolvency, Regulations issued by the Board of Directors of DIFC Concerning DIFC Insolvency Regulation, DIFC Law No (10) of 2004 Concerning the Court of DIFC and legislation in force in the Emirate of Dubai.

3/ Sir Anthony Evans, who is the Chief Justice of the DIFC Courts and a former High Court Judge of England and Wales; Michael Hwang, SC, who is the Deputy Chief Justice of the DIFC Courts and a former Judicial Commissioner of the Supreme Court of Singapore; and Justice Sir John Murray Chadwick who is Judge of the DIFC Courts and a former Judge of the Court of Appeal of England and Wales and is a world renowned bankruptcy and insolvency specialist. 
22. Based on the WEO's oil price projections, the overall fiscal position is projected to return to a surplus of about 10 percent of GDP in 2010. Over the medium term, the overall surplus will increase to about 15 percent of GDP, mainly due to a gradual increase in non-oil revenues associated with the introduction of the VAT. Abu Dhabi is expected to record sustained, large oil-driven surpluses over the medium term, while the GD would move to a balance position as some large investment projects are completed.

23. The fiscal policy stance will deviate from the sustainable path in the short term in order to mitigate the impact of the downturn and support non-oil economic diversification. Over the medium term, however, the gap is projected to close. ${ }^{5}$ In 2010 , the nonhydrocarbon deficit is projected to contract by about 4 percentage points, to 30 percent of NHGDP, owing mainly to a slowdown in project implementation in Abu Dhabi, and to improve over the medium term because Abu Dhabi is not expected to continue providing support to its GREs. ${ }^{6}$

24. The external current account is expected to shift to a surplus of about 7 percent of GDP in 2010, and to increase gradually in subsequent years. In the financial account, capital outflows would resume, reflecting official outward investment, but the Central Bank of the United Arab Emirates' (CBU) gross official reserves would increase steadily.

25. The staff also prepared a downside scenario in which non-oil growth, oil prices, and crude production remain at or below their depressed 2009 levels ( 0 percent, \$62 per barrel, and $2.4 \mathrm{mbpd}$, respectively). This scenario would correspond to low external demand, especially from Asia, which would dampen the prospects for the oil, trade, and hospitality engines and erode the external and fiscal positions. Under this scenario, problems in Dubai's property sector would contaminate Abu Dhabi and the balance sheets of: (i) nonproperty corporates (lower earnings and no external financing); (ii) households (job losses for nonnationals; lower rental income for nationals); and (iii) commercial banks (lower earnings; rising nonperforming loans (NPLs)). In addition, rising sovereign debt and contingent liabilities would constrain fiscal policy, especially in Dubai; and the balance of payments and fiscal positions would take longer to return to surplus.

\section{Downside risks could materialize if the Dubai debt restructuring were to}

generate additional uncertainty. It is important that uncertainty be removed regarding the financial viability of DW entities, the extent of implicit government guarantees to GREs, and the insolvency regime. If uncertainties remain in these areas, ramifications could include

\footnotetext{
${ }^{5}$ Development expenditure and transfers to GREs are excluded from the calculation of the fiscal deficit as it is assumed that they yield a return on investment equal to the discount rate used in the calculation of annuities.

${ }^{6}$ The rise and fall in the nonhydrocarbon deficit mostly reflects loans and equity from Abu Dhabi to its GREs. As such, the timing of the impact on economic activity is uncertain because the outlays are not direct spending by the government and can be used to allow GREs to borrow or to finance multiyear investment projects.
} 
sustained lack of market access for even stronger Dubai entities and/or a more permanent loss of confidence in Dubai as a reliable business location.

\section{Report on the Policy Discussions}

27. The policy discussions focused on (i) the lessons of the global crisis for the U.A.E. business model; (ii) the implications of recent events for the macroeconomic outlook, including the banking system; and (iii) the Dubai debt situation and its potential spillovers through real and financial channels. Particular attention was given the policy mix for balanced and sustainable growth, the macroprudential lessons from the crisis for financial stability policies, and the importance of transparency and disclosure for an orderly restructuring of Dubai's GREs.

\section{A. The Dubai Model}

28. Even though Dubai has achieved an impressive degree of diversification and has become a major trading and services regional hub, recent events call into question the sustainability of enhancing growth through large-scaled and highly leveraged property development. The Dubai authorities recognized that the recent events require a reassessment of Dubai's real estate sector to ensure the economic and financial viability of the emirate's corporate sector. As a result, over the medium term real growth was likely to be slower but more sustainable than in the period preceding the crisis. The authorities were of the view that Dubai had a top quality infrastructure, and that its hospitality, trade and logistics engines should continue to benefit from Asia's pull. Although the scope of the restructuring was still being defined, the focus would be on refinancing the property sector.

\section{B. Policy Mix on the Exit Path from the Crisis}

29. The authorities noted that their policy response had been successful in stabilizing the economy. Countercyclical fiscal policy had played a key role in avoiding a major disruption in economic activity, and the timely financial support provided by the CBU before the crisis had prevented problems in the banking system. In addition, Abu Dhabi's support of Dubai had limited contagion to the economy and banking system during 2009.

30. The exit path from the crisis, however, is fraught with uncertainties related to developments in global liquidity, capital flows, and the possible implications of Dubai's debt restructuring. Prior to the announcement of the debt standstill, there were early indications that global liquidity was again finding its way into the U.A.E.: (i) foreign buying on the equity markets; (ii) deposit inflows from the Asia subcontinent and the Arabian Peninsula attracted by higher interest rates; (iii) significant price gains for bonds issued by U.A.E. entities; and (iv) signs of increasing prices for high-end Dubai properties. With developed economies continuing to provide cheap liquidity to the global financial system, the authorities were facing the possibility of having to manage renewed capital inflows. 


\section{The debt standstill announcement raised concerns about a possible reversal of}

capital flows, but the authorities indicated that they had not noticed any significant changes in cross-border flows within the banking system following the announcement, and that so far commercial banks had not made use of the new liquidity facility introduced by the CBU. It cannot be ruled out, however, that the uncertainties associated with the process and outcomes of corporate debt restructuring in Dubai could lead in the future to capital outflows.

\section{In this context, the policy mix should be mutually supportive and flexible enough} to tackle possible emerging tensions. Overheating could arise from the combination of the expansionary fiscal policy and the limitations of monetary policy in slowing down capital inflows. On the other hand, liquidity pressures arising from deposit withdrawals and capital outflows could lead to a further tightening of credit conditions, with adverse effects on economy activity.

- Monetary policy: The authorities indicated that in case of renewed capital inflows they would be prepared to sterilize partially the impact on the monetary and credit aggregates by raising reserve requirements. In case of temporary pressures due to deposit withdrawals and capital outflows, the central bank would be prepared to inject liquidity through their various facilities. As a general point, however, the authorities recognized the limitations of monetary policy in the context of an economy with a fixed exchange rate and capital mobility, and indicated that the macroprudential policies would also need to play an important role in dealing with potential pressures.

- $\quad$ Fiscal policy: The authorities agreed on the need for fiscal policy to play a role in moderating the impact of the crisis on economic activity, but stressed that it was important to preserve fiscal sustainability and avoid excesses. They also noted the challenges of coordinating the fiscal stance and debt management at the federal level. ${ }^{7}$ They indicated that the establishment of a Fiscal Coordination Committee a year ago, initiatives to develop multi-year rolling expenditure plans, and recent steps to coordinate debt management between the federal government and the emirates through the creation of debt management units would help improve coordination. As a medium-term measure, the authorities stated that they had plans to adopt a VAT in 2012 in order to widen the tax base and reduce the dependency on hydrocarbon revenues.

\section{Dubai's Debt Restructuring and Potential Spillovers}

33. The ramifications of the Dubai event are still unfolding, as it will take some time for the GD to develop a strategy to restructure its GREs. The analysis is complicated by the lack of information on DW's and many Dubai GREs' balance sheets and cash flows, including asset valuation, nonfinancial debts, and bilateral bank loans. As a general point,

\footnotetext{
${ }^{7}$ The emirates exercise autonomy over their own natural resources and fiscal policy.
} 
external funding for Dubai GREs and private companies is likely to become more expensive and limited at least until the property overhang is substantially absorbed.

34. The Dubai authorities stressed that they were committed to working with creditors in achieving an orderly and cooperative debt restructuring. They recognized that the debt standstill announcement had created unnecessary uncertainty and market tensions, and that there was scope to improve their communications strategy. They also indicated that they were working on improving transparency and corporate governance. This was regarded as important for viable companies to maintain access to international capital markets. In addressing the transparency issue, however, it is clear that providing more information would require some time given the complexity of DW's corporate structure and the web of its investments, as well as the need to develop an appropriate statistical infrastructure.

35. The authorities noted that the scope of the corporate restructuring and the debt restructuring options were still being defined (Box 2). Restructuring would seek to ensure economic and financial viability while protecting systemically-important entities. In this regard, the authorities underlined that the entities whose debts were subject to restructuring had valuable assets in their overall portfolios. So far the debt restructuring is limited to the announced $\$ 22$ billion, but the authorities recognized that other property GREs may have to enter a similar process.

36. The authorities emphasized that the crisis had encouraged greater cooperation between the federal and emirates levels of government and between the emirates themselves. Going forward, Abu Dhabi would continue to support Dubai in its efforts to achieve a viable position. However, the Abu Dhabi authorities emphasized that Abu Dhabi was not legally liable for DW debt and that any decision to extend support would be made on a case-by-case basis. In this regard, they stressed that they did not want to create moral hazard by supporting potentially nonviable corporations, but would provide support if necessary to limit contagion to the U.A.E. economy and banking system.

37. The spillover effects of the Dubai event on the GCC, the wider region, and advanced economies appear manageable (Box 3 ). However, the event may have a lasting impact on the availability and cost of external capital as creditors likely will further discount notions of implicit guarantees in pricing quasi-sovereign and private risk. 


\section{Box 2. Considerations on Restructuring of State-Owned Entities}

While there are widely accepted principles for sovereign and corporate debt restructurings, specific best practices for the restructuring of state-owned entities are less clear. Nonetheless, an over-arching principle is that such entities should be subject to the regular corporate insolvency law as far as possible. Since the sovereign as shareholder will be involved in debt and operational restructuring of the state-owned entities, this will affect the implementation of some of the principles and tools used in debt restructuring. The following considerations are pertinent.

- Transparency and predictability. Transparency and predictability play key roles in building strong investor relations and reliable access to capital markets. There needs to be a clear line about the level of support the state-owned entities enjoy from the sovereign. Corporate governance, transparency, financial disclosure and audit standards need to be brought up to international standards such that the company and investors are able to interact in a predictable and transparent manner. Restructuring plans should be communicated clearly to the markets to anchor expectations about viability and credit worthiness and reduce speculation.

- Equal treatment of creditors. The process needs to be in line with best practices of equal treatment of creditors, including nondiscrimination of foreign creditors. For instance, in restructuring negotiations, all creditors should be consulted in a transparent, collaborative, and equitable manner. Such an open process facilitates debt restructuring in a rapid and orderly way to arrive at a solution that minimizes disruption to international trade and finance.

- Importance of operational restructuring and corporate governance. Debt restructuring needs to be accompanied with other measures to promote long-term corporate health and prevent future debt restructurings. These measures include scaling/closing down nonviable businesses, asset sales, and improvements in financial disclosure and audit standards. Cross country experience shows that even in successful debt restructuring episodes, operational restructuring is often sluggish, slow, and inadequate. Given their concerns over unemployment and public opinion, governments may be hesitant to down-size or close nonviable businesses. Support mechanisms such as debt rollovers, guarantees, below market interest rates and grace periods can become tools for propping up nonviable companies and postponing the required operational restructuring.

- Costs to sovereign's balance sheet. The plan for government support (e.g. lending, establishment of asset management companies, and recapitalizations) needs to be clearly laid out and fiscal costs and contingent claims carefully evaluated to avoid excessive risks to the sovereign's balance sheet. The bailout of commercial entities which are not guaranteed should be minimized to avoid moral hazard and burdening the sovereign's balance sheet. 


\section{Box 3. Spillover Risks}

The GCC: The main channel of transmission to the rest of the GCC would be through the balance sheets of banks and other financial institutions. Although developments are still unfolding, available information so far indicates that the impact is likely to be limited, assuming that the debt restructuring remains contained. From a countryspecific perspective, regional financial institutions exposures seem to be manageable, at least based on publiclyknown direct exposures. Since the source of the slowdown in the U.A.E. comes from the property development sector and real estate prices, direct contagion (from Dubai-based entities operating in the GCC and foreign corporates affected in Dubai) could result in a decline in construction-related activity in the region. The impact through trade channels is likely to be limited: Dubai's economy accounts for less than 10 percent of GCC GDP, and intra-GCC trade is less than 10 percent of total GCC trade.

The wider region: Indirect spillovers from cross-border foreign direct investment and remittance flows could also have an impact on the wider region, including the Indian subcontinent. In the U.A.E., migrants represent around 3.5 million of residents, and outward remittances amounted to $\$ 10$ billion in 2008. Even though about 70 percent of these remittances accrue to India and Pakistan, the most affected countries, in proportion to GDP, would be Jordan, Bangladesh, and Egypt.

Advanced economies: U.A.E.-originated foreign investments, which are mostly directed to the advanced economies, are likely to be scaled down as the slowdown would force SWFs and corporates to reduce their expansion abroad. In addition, the Dubai restructuring could involve asset sales. The lack of comprehensive data makes it difficult to assess banks' exposure to DW and Dubai Inc., but available information indicates that the impact is likely to be limited. According to BIS data, the direct exposure of international banks to the U.A.E. does not appear to have systemic significance, although the indirect effects are unknown.

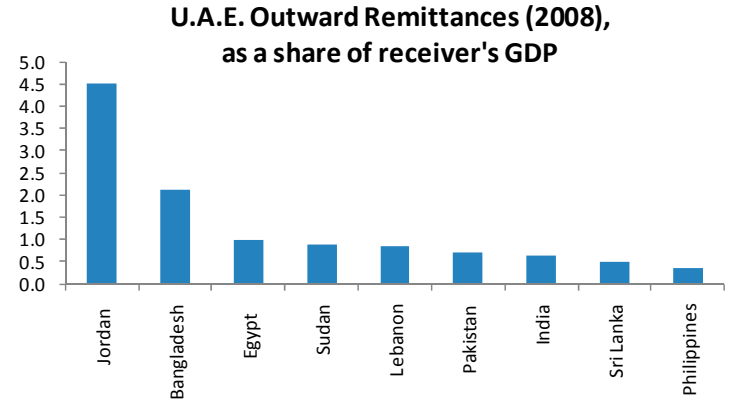

Sources: National central banks; World Bank; and Fund staff estimates.

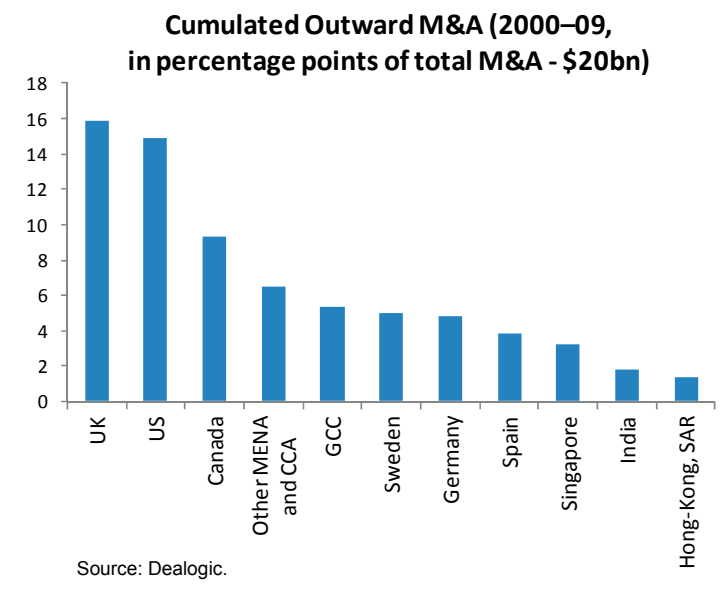

\section{Financial System Stress Analysis}

\section{The U.A.E. financial system entered} the global crisis exposed to a highly leveraged economy. The system is bank-based and focused on the domestic economy. Commercial banks expanded credit very aggressively during 2004-08, generating about $\$ 100$ billion of credit above the underlying trend growth. Credit growth was the fastest among emerging markets

\begin{tabular}{|c|c|c|c|c|c|c|}
\hline & \multirow{2}{*}{$\begin{array}{l}\text { Nonperforming } \\
\text { Loans }\end{array}$} & \multicolumn{2}{|c|}{ Capital Adequacy: } & \multirow{2}{*}{$\begin{array}{l}\text { Provisioning } \\
\text { Rate }\end{array}$} & \multicolumn{2}{|c|}{ Return on: } \\
\hline & & Latest & Pre-crisis & & Assets & Equity \\
\hline Bahrain 1/2/ & 2.3 & 18.1 & 21.0 & 84.0 & 1.3 & 16.9 \\
\hline Kuwait 2/ & 3.1 & 16.0 & 18.5 & 84.7 & 3.2 & 27.8 \\
\hline Oman 2/ & 2.9 & 14.7 & 15.1 & 119.3 & 2.3 & 14.1 \\
\hline Qatar 2/ & 2.0 & 15.6 & 13.5 & 83.2 & 2.6 & 20.7 \\
\hline Saudi Arabia 2/ & 1.4 & 16.0 & 20.6 & 153.3 & 2.3 & 22.7 \\
\hline U.A.E. 3/ & 4.6 & 18.6 & 13.3 & 79.0 & 1.5 & 12.1 \\
\hline Brazil 4/ & 4.3 & 18.5 & 18.7 & 157.3 & 1.1 & 11.6 \\
\hline Singapore $5 /$ & 1.4 & 14.3 & 13.5 & 119.9 & 1.1 & 11.9 \\
\hline \multicolumn{7}{|c|}{ Sources: Country authorities; and GFSR. } \\
\hline \multirow{2}{*}{\multicolumn{7}{|c|}{$\begin{array}{l}\text { 1/ Conventional banks with retail banking license. } \\
\text { 2/ Data generally for 2008, except Oman, June } 2009 \text { and Qatar, Sep. } 2009 . \\
\text { 3/ November 2009; national banks only. Tier } 1 \text { CAR: } 15.4 \% \text {. }\end{array}$}} \\
\hline 4/ May 2009. & $5 / 2008$, local t & anks only. & & & & \\
\hline
\end{tabular}


by a good margin, and the capital base was disproportionately low for such growth (figure 4). During this period, banks by and large did not retain sufficient profits to maintain capital buffers, despite their exposure to an economy with significant leverage. Nevertheless, banks remained highly rated throughout 2004-08, in part reflecting perceived support from governments and in some cases government ownership. In addition, banks' liabilities (deposits and interbank loans) have been under 3-year blanket federal government guarantees since September 2008.

Figure 4. United Arab Emirates: The Over-Extended Financial Sector Receives Strong Support
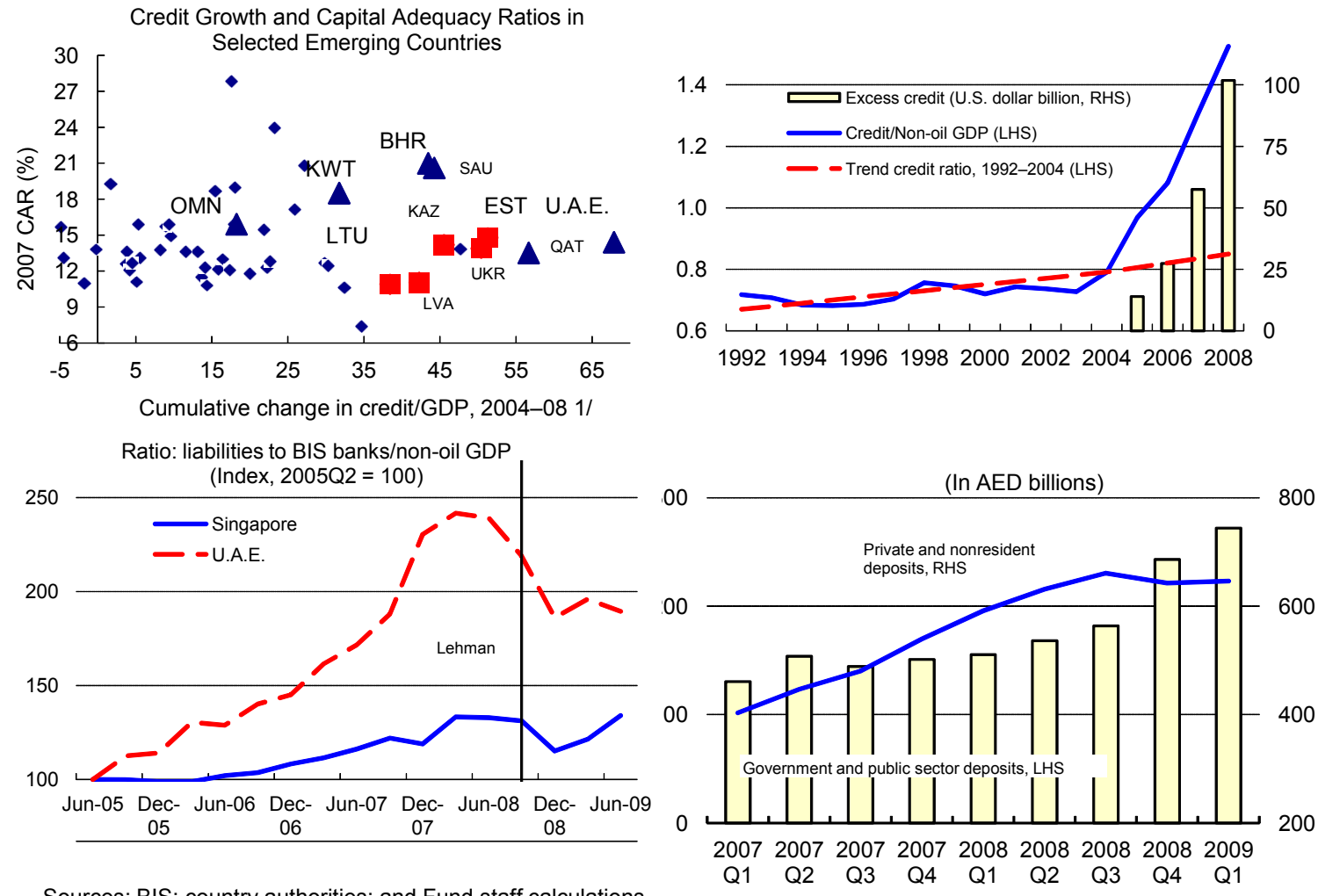

Sources: BIS; country authorities; and Fund staff calculations.

1/ For the GCC, GDP is non-oil GDP.

39. The authorities quickly recognized the need to shore up bank capital as the global financial crisis intensified. In the event, the average capital adequacy ratio of national banks increased from 13 percent to 18 percent, mainly from government capital injections of $\$ 16$ billion. These measures validated the notion that U.A.E. banks operated with a strong presumption of official support. The federal government also provided substantial term deposits that were subsequently converted into tier 2 capital, conditional on the banks increasing equity capital in the form of preferred shares subscribed by the emirati governments. The tier 1 CAR is currently about 15 percent, while tier 2 CAR is about 3 percent. 
40. Prior to the DW announcement in November, the preemptive recapitalization of the national banks appeared sufficient to handle significant contingencies (Box 4). Stress tests showed that mainly the Dubai-based institutions would fall slightly below 12 percent capital adequacy if loan losses were five times ${ }^{8}$ pre-crisis levels, and that all major banks would stay above this minimum if losses were to increase three-fold. A five-fold increase in loan losses would be equivalent to a 25 percent loss on the excess credit that built up during the bubble period. If such contingencies were to materialize, additional capital of $\$ 3$ billion (about 1.3 percent of 2009 GDP) would be needed to keep all the banks above 12 percent capital adequacy, the new regulatory minimum becoming effective in June 2010.

\footnotetext{
${ }^{8}$ This level of stress is consistent with the recent experience of banking markets that were severely affected by property bubbles (Dublin, Madrid, and the most distressed U.S. real estate markets). In the case of the U.A.E., under these assumptions, the ratio of nonperforming loans would increase to 10 percent on average, from about 2 percent before the crisis.
} 


\section{Box 4. Methodology and Calibration of Stress Test}

Given the pervasiveness of real estate risk in the U.A.E., staff used balance sheet data from banks operating in key bubble property markets of the United States, Spain, and Ireland to calibrate the test. ${ }^{1}$ Loan losses of banks operating in these comparators have increased four-fivefold in the two to three years following the bubble bursting. ${ }^{2}$ This reflects a combination of: (i) the direct impact of bankruptcy and layoffs in frontline sectors (construction, property development, and related services); (ii) the indirect impact of job losses and corporate distress in sectors pulled down by the frontline (e.g., retail trade, corporate and personal services); and (iii) expectation channels via consumer/business confidence and the associated increase in precautionary saving, especially among South Asian expatriates.

Loan Losses in the Aftermath of Property Bubbles, Selected Urban Markets
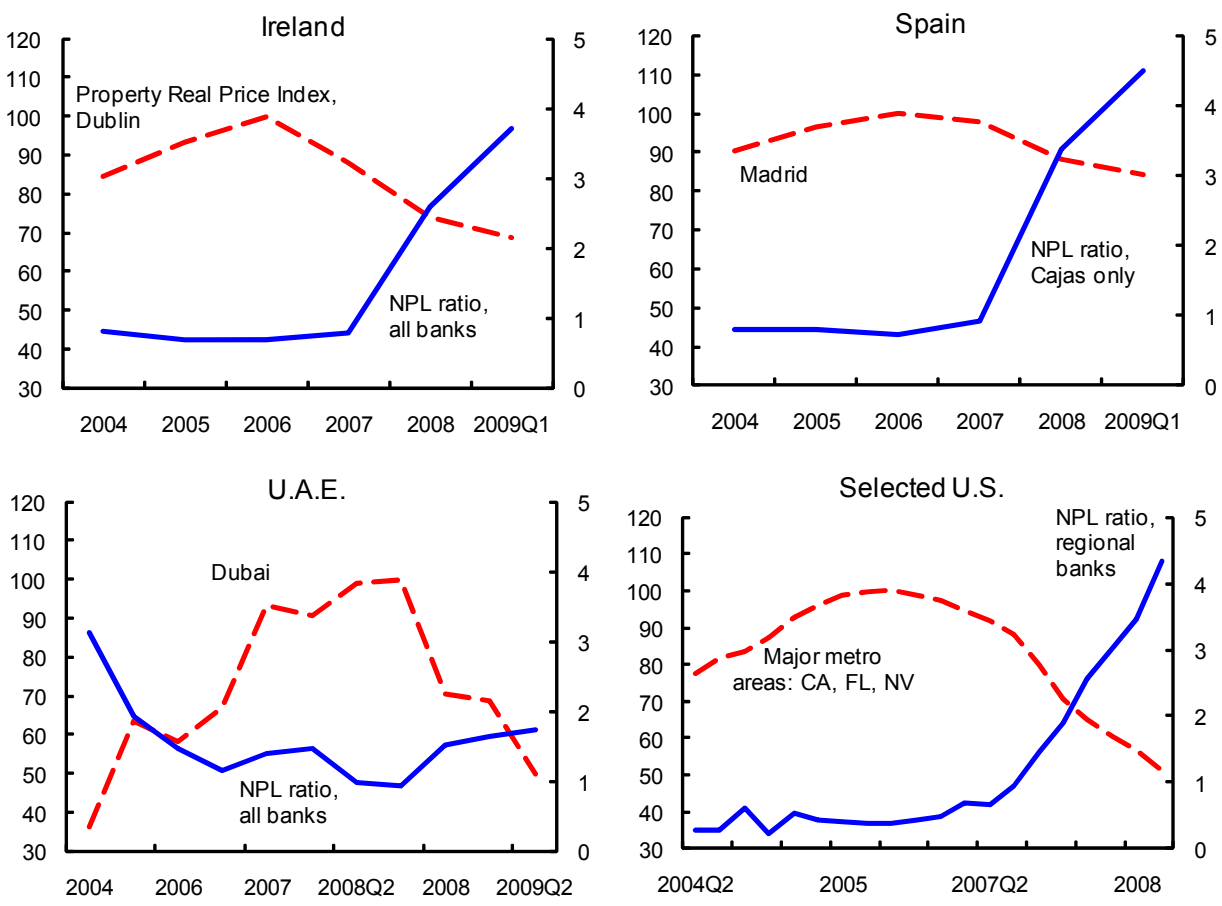

Sources: Haver; Case/Shiller (San Francisco, Los Angeles, San Diego, Miami, Tampa, Las Vegas); Dubai Land Department; Bankscope; and GFSR.

Text table 4 summarizes the key results and provides methodological details and parameters.

1/ Official data show that U.A.E. banks' exposures to real estate declined in recent years, possibly reflecting the increased importance of external financing of such activities. Regulation caps real estate lending at 20 percent of deposits. As the indirect effects of bursting bubbles are powerful, using property exposure in a narrow sense would be insufficient.

2/ The October 2009 GFSR expected loss rates of 2 percent for Asia, 5 percent for Europe, 7 percent for the U.K. and 8 percent for U.S. banks.

\section{However, the DW debt situation has increased the need for additional capital as these contingencies have become more likely to materialize.}

- $\quad$ The uncertainty created by the prospective debt restructuring implies that banks may need material capital buffers above the regulatory minimum to maintain adequate 
ratings for dealing with market counterparties. To illustrate, assuming that banks need at least a 14 percent CAR, the additional capital needs would be about $\$ 6$ billion or 2.7 percent of GDP.

- The possibility of a principal haircut on the DW debt subject to the standstill cannot be ruled out, an outcome which would have a significant effect on banks' provisioning. As an illustration, staff estimates that the capital top up could reach 3.4 percent of GDP for a 25 percent haircut and 4.3 percent of GDP for a 50 percent haircut of DW debt subject to the standstill.

42. While the extra capital need appears manageable, the exercise underscores the importance of contingency planning, supported by intensified supervision. The global financial crisis is testing the $\mathrm{CBU}$ as a regulator, as it did with many other regulators. The DW standstill has increased the potential for surprises and, consequently, the need for a more pro-active supervisory approach and effective enforcement. The CBU could for example use more systematically its power to block dividend distributions in the interest of building larger capital buffers. There may also be a need to re-assess how exemptions to large exposure limits are granted in the case of GREs. Finally, CBU inspections follow a traditional model of rolling examinations of individual institutions, whereas the current situation suggests the need for simultaneous cross-firm examinations of specific risks such as sectoral concentration, name-lending, or deteriorating funding standards. In the latter case, the CBU's limited resources, including for off-site analysis, hinders such an approach.

43. The authorities also agreed that macroprudential policies could be used in the future to mitigate systemic risk by helping to slow down the formation of credit and asset bubbles. This could be achieved through a menu of:

- $\quad$ Counter-cyclical solvency measures: dynamic provisioning, lower dividend distribution for fast expanding banks, higher capital charges for systemic banks;

- $\quad$ Counter-cyclical liquidity measures: varying loan-to-stable funding ratios; reserve requirements;

- $\quad$ Systemically important U.A.E. banks could be encouraged to issue convertible debt instruments (debt that converts into equity, subject to timing clauses or other triggers), preferably in the international market, to supplement local regulatory scrutiny with that of international investors.

44. The authorities also indicated that they were looking at other options, such as direct limits on corporate borrowing and bank credit growth, and measures to counter renewed speculative pressures in the real estate sector, including:

- More frequent and closer monitoring of bank lending practices related to this sector; 
Text Table 4. Stress Analysis 1/

\begin{tabular}{|c|c|c|c|c|}
\hline & Dubai-based banks & Abu Dhabi banks & Other emirates & Total 4/ \\
\hline Number of banks & 7 & 5 & 5 & 17 \\
\hline Share of sample assets & $46 \%$ & $47 \%$ & $6 \%$ & $100 \%$ \\
\hline \multicolumn{5}{|c|}{ Stress test excluding restructuring of Dubai World bank debt $2 /$} \\
\hline \# banks below $12 \%$ CAR & 5 & 2 & 1 & 8 \\
\hline Recap. needs ( $\$$ bn) & 2.2 & 0.5 & 0.2 & 2.9 \\
\hline In $\%$ of emirate GDP & 2.8 & 0.3 & 7.9 & $1.3 \%$ \\
\hline \# banks below $14 \%$ CAR & 5 & 3 & 1 & 9 \\
\hline Recap. needs ( $\$$ bn) & 4.2 & 1.7 & 0.3 & 6.2 \\
\hline In $\%$ of emirate GDP & 5.3 & 1.2 & 9.8 & $2.7 \%$ \\
\hline \multicolumn{5}{|c|}{ Stress test including illustrative $25 \%$ haircut on DW standstilled debt $3 /$} \\
\hline \# banks below $14 \%$ CAR & 6 & 3 & -- & 9 \\
\hline Recap. needs ( $\$$ bn) & 5.5 & 2.3 & -- & 7.8 \\
\hline In $\%$ of emirate GDP & 7.1 & 1.6 & -- & $3.4 \%$ \\
\hline \multicolumn{5}{|c|}{ Stress test including illustrative $50 \%$ haircut on DW standstilled debt } \\
\hline \# banks below $14 \%$ CAR & 7 & 3 & -- & 10 \\
\hline Recap. needs ( $\$$ bn) & 7.0 & 2.8 & -- & 9.8 \\
\hline In $\%$ of emirate GDP & 9.1 & 2.0 & -- & $4.3 \%$ \\
\hline
\end{tabular}

Sources: Authorities, Bankscope, and Fund staff estimates and calculations.

1/ Sample includes national banks. Foreign banks (25 percent of system assets) are excluded.

2/ Stress would fully materialize by 2011 under following assumptions:

Credit is key risk and is driven by the deflating property and lending bubbles.

Loan losses (5 times pre-crisis) calibrated from event study of the Madrid, Dublin and selected US bubble markets.

Further loss of $10 \%$ on investments from 2009Q3 (securities for sale and held to maturity, and property investments).

Profits in 2009 and 2010 are half of 2008 and are fully retained to cover losses, all of which banks recognize by 2011.

Post-shock risk weighted assets $=90$ percent of end-2008 RWA, from banks' on-going de-risking of balance sheets.

$12 \%$ CAR is minimum required by regulator as of June $2010 ; 14 \%$ is assumed minimum required by counterparties.

Emirate GDP is a proxy for fiscal capacity to recapitalize an emirate's banks.

$3 /$ Standstilled debt refers to bank loans and bonds that are subject to restructuring negotiations.

$4 /$ "\%" in this column is percent of UAE GDP.

- The possible introduction of a capital gains tax on property transactions (registered by the Dubai Land Department) and on securities that derive their value from real property;

- A more active Real Estate Regulatory Authority as concerns compliance with Anti-Money Laundering (AML) regulations by property developers, brokers, and other intermediaries. This could help slow down transactions that do not require local financing.

45. The CBU is currently working on tightening the regulatory framework. It is in consultations with banks on introducing a general provision for unclassified loans and advances equal to 1.25 percent of risk-weighted assets, ${ }^{9}$ and on standardizing loan classification across the industry on the 90 -day past due practice used by the listed banks. Regarding inspection, the CBU is focusing on enforcing provisioning standards more uniformly. The CBU has also asked the banks exposed to troubled Saudi Arabia conglomerates to increase provisioning immediately. The authorities also indicated they would request that an FSAP update be conducted in late 2010.

\footnotetext{
${ }^{9}$ Federal and local government loans and loans guaranteed by them will be exempted.
} 


\section{E. Exchange Rate Assessment}

\section{CGER approaches (equilibrium real exchange rate (ERER), macrobalance} (MB), and external sustainability (ES)) used to assess $^{10}$ the level of the exchange rate suggest that the U.A.E. dirham is broadly in line with fundamentals. Under the $M B$, the projected medium-term current account surplus for the U.A.E. is close to the "norm" for oil exporters. Under the ES, however, the projected current account surplus is lower than its norm - the current account surplus that stabilizes per capita non-oil current account deficits - suggesting that surpluses are below intergenerational equity needs. These results, however, are subject to well-known estimation difficulties for oil-exporters and are very sensitive to the assumptions used. ${ }^{11}$

\section{The authorities view the peg of the dirham to the U.S. dollar as appropriate.}

They cited the composition and invoicing of trade, low consumer price inflation, and the current similarity with the U.S. business cycle as relevant factors in favor of maintaining the peg, at least in the medium term.
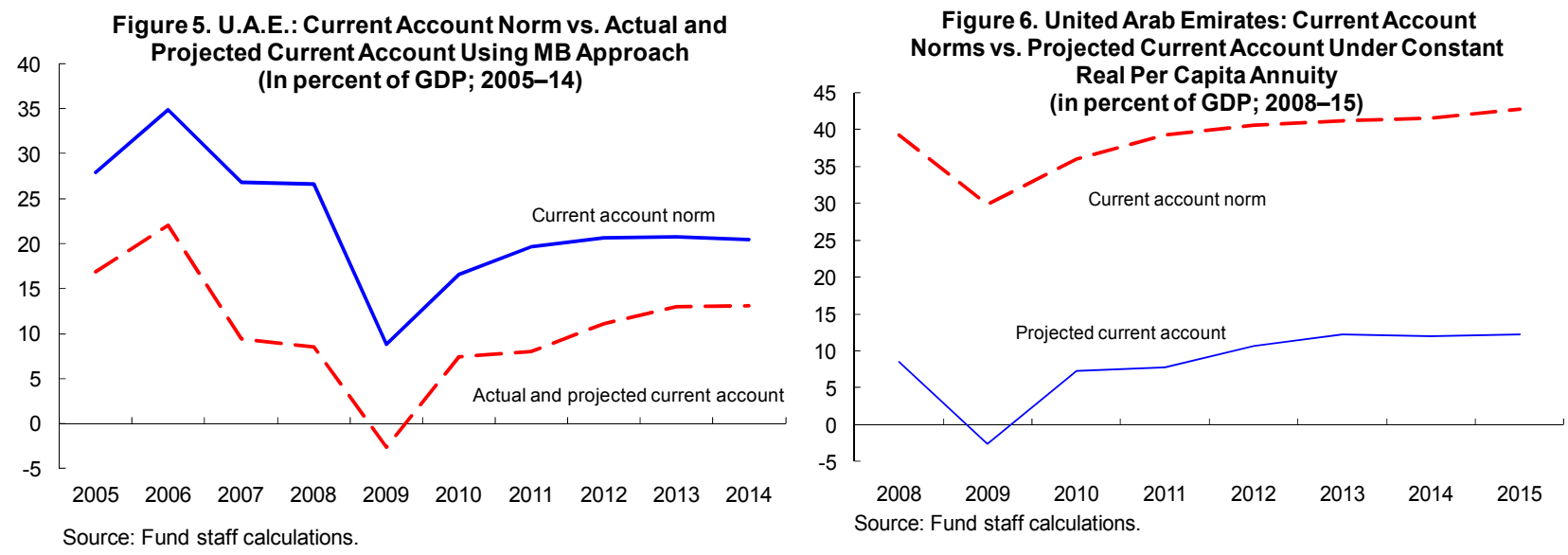

\section{F. Structural Issues}

48. Labor markets. The development model and future growth prospects of the U.A.E. continue to rely on imported labor that provides the workforce needed in an increasingly diversified economy. The authorities noted that strengthening the skills mix of the labor force was an important challenge as the economy moved away from construction as the major engine of growth. They agreed that measures facilitating movement in the labor market or

\footnotetext{
${ }^{10}$ Key variables include the fiscal balance, net foreign assets, and oil prices.

${ }^{11}$ The current account norm under the ES is particularly sensitive to assumptions about population growth and the real rate of return on investment.
} 
providing a minimum safety net for expatriate workers are likely to enhance the attractiveness of the U.A.E. as a work place for qualified workers.

49. Long-term financing. The growth model of the U.A.E. is likely to require access to substantial long-term capital to continue to improve infrastructure and implement large mega-projects. Domestic markets are unlikely to provide this kind of financing, which would generate persistent funding gaps that in the past were filled by resorting to foreign borrowing of relatively short maturities. The authorities noted the need to develop local debt markets and indicated that various laws and regulations were being drafted to develop a treasury securities market to help finance government development projects, as well as improving payment and securities clearance and settlement systems.

50. Data. The authorities recognized the need to strengthen the macroeconomic and financial statistics in order to address the existing weaknesses that hamper economic monitoring and policy formulation. To that end, an initiative to compile consolidated government finance statistics at the federal level has started, some high frequency leading indicators have been launched, and debt management units have been established at the federal and emirate levels. The authorities have also adopted a new federal statistics law that provides for (i) the establishment of an independent federal statistics bureau (the NBS), and (ii) coordination between the federal and emirates levels for the collection, compilation, and dissemination of data. The NBS was established in 2009 with a Board of Directors consisting of representatives from all emirates to set the national statistics strategy. In addition, several committees have been formed to coordinate data collection and agree on appropriate methodologies. The NBS has indicated its intention to request Fund TA to help implement the new federal framework.

\section{Staff APpraisal}

51. In 2009 the U.A.E. economy was adversely affected by several shocks, including the impact of the global financial crisis, lower oil prices, and the fallout from the bursting of the Dubai property bubble. Against this backdrop, the authorities responded decisively to maintain confidence in the financial system and boost aggregate demand through the implementation of major infrastructure and strategic projects. The recent announcement by DW that it would seek a standstill and restructuring of \$22 billion of debt has raised new important challenges. In addition to an expeditious restructuring, these include the need for greater transparency, clearer demarcations between governments' purely commercial and other activities, and a much more prudent approach to project/investment evaluation and debt management. As a result of these developments, in the coming years the economies of Dubai and the U.A.E. are likely to grow at a slower (but more sustainable) pace than in the years preceding the current crisis. 
52. It is essential for the government of Dubai to proceed with an orderly, predictable, and cooperative approach to debt restructuring, ensuring inter-creditor equity. In this connection, there is scope to improve the communications strategy and an urgent need to enhance transparency and the disclosure of information. At a minimum, financial statements and balance sheets of Dubai Inc. corporations should be published as for listed corporations, and their operational relations with the government clarified. The government should seek to avoid using continuing government support (direct or through guarantees) that could make a restructuring easier to achieve but contribute to moral hazard and weak credit appraisal going forward.

53. In tandem with the debt restructuring, the Dubai authorities should move ahead with the operational restructuring of the emirate's GRE sector in order ensure its economic and financial viability, without recourse to government guarantees. This will require a thorough analysis of all the corporations, including those outside DW, to define the scope of the restructuring; a careful reassessment of investment projects to avoid duplication, increase synergies, and improve overall efficiency; and the development of a clear exit strategy for nonviable businesses.

54. There is also a need to articulate a contingency plan for the banking system in order to deal with a potential deterioration in asset quality. The authorities have taken a number of steps to strengthen commercial banks, but the DW standstill has increased the need for further measures. There is evidence that NPLs have been increasing, and the restructuring is likely to further impact corporate and household balance sheets. Particularly close attention should be paid at the implications of reduced payments by real estate developers and other companies to their suppliers because of the cascading effect and possible repercussions for NPLs. In this context, the authorities should press ahead with their plans to introduce a general loan provision, standardize loan classification, strengthen on-site and off-site supervision, and enforce more uniform provisioning standards. In addition, consideration should be given to further strengthening the banks' capital, including by converting the tier 2 capital already injected by the federal government into tier 1 capital. The authorities' intention to request that an FSAP update in be conducted in late 2010 is welcome. In this context, staff recommends an assessment of corporate governance of banks and other nonbank listed companies, a review of insolvency and creditor rights, and an evaluation of the CBU's crisis preparedness framework.

55. The exit path from the global economic crisis will be fraught with uncertainties, and the policy mix should be supportive and flexible enough to tackle emerging tensions. Overheating could arise from the combination of the expansionary fiscal policy and the limitations of monetary policy in slowing down a renewal of capital inflows, while liquidity pressures could emerge if uncertainties were to trigger capital outflows or deposit withdrawals. In this context, fiscal policy should continue to play a compensatory role to sustain economic activity, and the central bank should stand ready to either sterilize liquidity, 
including by increasing reserve requirements, or to inject it, if necessary, through the new liquidity facility introduced after the standstill announcement.

56. Given the limitations of monetary policy in an economy with capital mobility and a fixed exchange rate regime, macroprudential policies are called to play an important role over the medium term. Specific policies could include (i) counter-cyclical solvency and liquidity measures and close monitoring of lending/funding practices, including through targeted horizontal inspections across banks within a short time frame. Staff would caution against the introduction of direct controls or credit limits because of their distortionary effects and limited effectiveness in an open economy such as the U.A.E.

57. The main spillover effects of the Dubai event are likely to include a slowdown of foreign direct investment and project-related financing by Dubai to other countries in the MENA region, and possibly reduced remittances to key emerging economies, including India and Pakistan. More generally, investors will start to look more carefully at implicit guarantees, and there will be a reassessment of quasi-sovereign commercial risks. In this context, transparency and the timely provision of information on quasi-sovereign commercial entities will be crucial for viable corporations to maintain access to international markets.

58. The efforts being made to strengthen policy coordination at the federal level after the Dubai event should be intensified, while avoiding a duplication of activities and institutions at the emirates level. Coordinating the fiscal stance at the federal level, while reducing leverage through appropriate debt management, will be a challenge. In this regard, the establishment of a Fiscal Coordination Committee, the development of multi-year rolling expenditure plans, and the creation of debt units at the federal and emirates levels to coordinate debt management are important steps in the right direction.

59. The adoption of the Federal Statistics Law and the related establishment of the NBS are important steps in developing statistical capacity at the federal level. Staff encourages the authorities to develop an action plan encompassing the issuance of implementing regulations (including the delineation of responsibilities among different agencies compiling statistics) and a strengthening of the operational independence (from the emirates) of the Board of Directors of the NBS. In that regard, an efficient collection of data, the harmonization of methodologies, and funding for training and development could be carried out more effectively by the NBS through branches in the emirates rather than by establishing independent statistics departments in each emirate. Staff also welcomes the initiative to compile consolidated government finance statistics and encourages the authorities to press ahead with other measures envisaged in the GDDS action plans, such as further developing the capacity to produce leading indicators and to collect and disseminate data on the U.A.E.'s IIP. 
60. The peg of the dirham to the U.S. dollar remains appropriate. The composition and invoicing of trade, low consumer inflation, and the similarities at this time with the U.S. business cycle suggest that the near-term benefits of maintaining the peg outweigh the costs of abandoning it.

61. Prospects for growth in the U.A.E.'s increasingly diversified economy are dependent on an ample supply of imported labor. An important challenge for the authorities will be to strengthen the skills mix and establish incentives to further facilitate labor mobility.

62. It is proposed that the next Article IV consultation take place on the standard 12-month cycle. 
Table 1. United Arab Emirates: Selected Macroeconomic Indicators, 2005-10

(Quota: SDR 611.7 million)

(Population: 5 millions, nationals: 1 million)

(Per capita GDP-2008: \$54,531; poverty rate: n.a.; unemployment rate: $4.0 \%(2008)$ )

\begin{tabular}{|c|c|c|c|c|c|c|}
\hline & 2005 & 2006 & 2007 & 2008 & $\begin{array}{c}\text { Est. } \\
2009\end{array}$ & $\frac{\text { Proj. }}{2010}$ \\
\hline \multicolumn{7}{|l|}{ Hydrocarbon sector } \\
\hline Exports of oil and gas (in billions of U.S. dollars) & 53.2 & 69.1 & 74.3 & 102.7 & 56.8 & 71.8 \\
\hline Average crude oil export price (in U.S. dollar per barrel) & 53.6 & 63.5 & 70.4 & 96.3 & 61.3 & 75.3 \\
\hline \multirow[t]{2}{*}{ Crude oil production (in millions of barrels per day) } & 2.4 & 2.6 & 2.5 & 2.6 & 2.4 & 2.5 \\
\hline & \multicolumn{6}{|c|}{ (Annual percent change, unless otherwise indicated) } \\
\hline \multicolumn{7}{|l|}{ Output and prices } \\
\hline Nominal GDP (in billions of AED) & 493 & 601 & 762 & 960 & 846 & 910 \\
\hline Nominal GDP (in billions of U.S. dollars) & 134.2 & 163.7 & 207.6 & 261.4 & 230.3 & 247.7 \\
\hline Real GDP (at factor cost) & 8.2 & 8.7 & 6.1 & 5.1 & -0.7 & 0.6 \\
\hline Real hydrocarbon GDP & 1.6 & 6.5 & -2.7 & 1.6 & -6.3 & 2.7 \\
\hline Real nonhydrocarbon GDP & 10.8 & 9.5 & 9.1 & 6.3 & 1.0 & 0.0 \\
\hline \multirow[t]{2}{*}{ CPI inflation (average) } & 6.2 & 9.3 & 11.6 & 11.5 & 1.0 & 1.5 \\
\hline & \multicolumn{6}{|c|}{ (In percent of GDP) } \\
\hline \multicolumn{7}{|l|}{ Investment and saving } \\
\hline Gross domestic investment & 20.8 & 21.6 & 20.5 & 22.5 & 23.0 & 19.8 \\
\hline Change in stocks & 1.2 & 1.1 & 1.0 & 1.6 & -0.9 & 0.4 \\
\hline Total fixed capital formation & 19.6 & 20.5 & 19.5 & 20.9 & 23.9 & 19.4 \\
\hline Public & 7.2 & 6.4 & 5.7 & 8.3 & 11.4 & 9.5 \\
\hline Private & 12.4 & 14.1 & 13.7 & 12.6 & 12.5 & 9.9 \\
\hline Gross national saving & 37.7 & 43.7 & 30.1 & 31.2 & 20.3 & 27.1 \\
\hline Public & 34.1 & 43.3 & 37.6 & 38.6 & 23.2 & 30.2 \\
\hline Private & 3.5 & 0.4 & -7.5 & -7.4 & -2.9 & -3.1 \\
\hline Savings/investment balance & 16.9 & 22.1 & 9.7 & 8.8 & -2.7 & 7.3 \\
\hline & & & In percen & of GDP) & & \\
\hline \multicolumn{7}{|l|}{ Public finances } \\
\hline Revenue & 41.4 & 49.7 & 43.4 & 46.9 & 34.6 & 39.7 \\
\hline Hydrocarbon & 31.0 & 38.2 & 30.9 & 37.7 & 25.7 & 30.9 \\
\hline Nonhydrocarbon & 10.3 & 11.6 & 12.5 & 9.2 & 8.9 & 8.8 \\
\hline Expenditure and net lending & 21.2 & 21.2 & 21.9 & 26.4 & 34.2 & 29.8 \\
\hline Current & 17.1 & 17.1 & 16.6 & 17.4 & 23.3 & 22.0 \\
\hline Capital & 3.9 & 4.0 & 5.0 & 8.7 & 10.6 & 7.5 \\
\hline Budget balance & 20.2 & 28.5 & 21.5 & 20.5 & 0.4 & 9.8 \\
\hline Non-hydrocarbon balance $1 /$ & -16.5 & -13.7 & -14.2 & -27.1 & -33.7 & -29.7 \\
\hline \multirow[t]{2}{*}{ Central government debt to banking system 2/ } & 9.2 & 10.1 & 9.7 & 15.1 & 26.4 & 22.1 \\
\hline & \multicolumn{6}{|c|}{ (Annual percent change, unless otherwise indicated) } \\
\hline Monetary sector & & & & & & \\
\hline Net foreign assets & 14.8 & -6.7 & 3.1 & -79.4 & 110.6 & 29.5 \\
\hline Net domestic assets & 62.2 & 54.9 & 66.3 & 58.2 & 4.5 & 3.9 \\
\hline Credit to private sector & 44.5 & 36.9 & 40.1 & 49.3 & 1.9 & 0.5 \\
\hline \multirow[t]{2}{*}{ Broad money } & 33.8 & 23.2 & 41.7 & 19.2 & 9.7 & 6.3 \\
\hline & \multicolumn{6}{|c|}{ (In billions of U.S. dollars, unless otherwise indicated) } \\
\hline \multicolumn{7}{|l|}{ External sector } \\
\hline Exports and re-exports of goods, of which: & 115.4 & 144.6 & 179.1 & 239.8 & 163.0 & 182.3 \\
\hline Hydrocarbon & 53.2 & 69.1 & 74.3 & 102.7 & 56.8 & 71.8 \\
\hline Nonhydrocarbon, excluding re-exports & 22.4 & 28.5 & 34.2 & 43.0 & 40.5 & 45.8 \\
\hline Imports of goods & -74.5 & -88.1 & -132.1 & -176.3 & -137.2 & -135.1 \\
\hline Current account balance & 22.7 & 36.2 & 19.5 & 22.2 & -6.2 & 18.1 \\
\hline Current account balance (in percent of GDP) & 16.9 & 22.1 & 9.7 & 8.8 & -2.7 & 7.3 \\
\hline External debt (in percent of GDP) 3/ & 30.6 & 49.2 & 62.7 & 52.0 & 56.3 & 56.4 \\
\hline Gross official reserves $4 /$ & 21.3 & 28.0 & 77.9 & 30.9 & 29.9 & 39.5 \\
\hline In months of next year's imports of goods \& services & 2.3 & 2.0 & 4.3 & 2.2 & 2.1 & 2.4 \\
\hline \multicolumn{7}{|l|}{ Memorandum items: } \\
\hline Local currency per U.S. dollar (period average) & 3.67 & 3.67 & 3.67 & 3.67 & 3.67 & 3.67 \\
\hline Nominal effective exchange rate $(2000=100)$ & 91.0 & 90.8 & 86.9 & 85.5 & 89.5 & .. \\
\hline Real effective exchange rate $(2000=100)$ & 93.4 & 98.5 & 101.4 & 105.5 & 110.7 & .. \\
\hline
\end{tabular}

Sources: U.A.E. authorities; and Fund staff estimates.

$1 /$ In percent of nonhydrocarbon GDP.

2/ Banking system claims only. Excludes debt raised by federal and emirati governments in the international markets.

3/ Mostly foreign liabilities of banking system; incomplete coverage of debt raised by non-banks in the international markets.

4/ Central bank only. Excludes unencumbered liquid foreign assets of sovereign wealth funds. 
Table 2. United Arab Emirates: Balance of Payments, 2005-10

(In billions of U.S. dollars)

\begin{tabular}{|c|c|c|c|c|c|c|}
\hline & 2005 & 2006 & 2007 & 2008 & $\frac{\text { Est. }}{2009}$ & $\frac{\text { Proj. }}{2010}$ \\
\hline Current account balance & 22.7 & 36.2 & 19.5 & 22.2 & -6.2 & 18.1 \\
\hline (In percent of GDP) & 16.9 & 22.1 & 9.7 & 8.8 & -2.7 & 7.3 \\
\hline Trade balance & 40.9 & 56.6 & 47.0 & 63.5 & 25.8 & 47.2 \\
\hline Exports & 115.4 & 144.6 & 179.1 & 239.8 & 163.0 & 182.3 \\
\hline Hydrocarbon & 47.4 & 62.0 & 66.1 & 91.1 & 50.2 & 63.2 \\
\hline Crude oil \& condensates & 42.2 & 56.4 & 61.2 & 85.4 & 47.8 & 60.3 \\
\hline Petroleum products & 5.2 & 5.6 & 4.9 & 5.7 & 2.4 & 2.9 \\
\hline Natural gas & 5.8 & 7.2 & 8.1 & 11.5 & 6.7 & 8.6 \\
\hline Nonhydrocarbon & 22.4 & 28.5 & 34.2 & 43.0 & 40.5 & 45.8 \\
\hline Exports by emirates & 5.0 & 8.0 & 11.5 & 16.4 & 14.7 & 16.6 \\
\hline Free zone exports & 17.4 & 20.5 & 22.8 & 26.5 & 25.8 & 29.2 \\
\hline Re-exports $1 /$ & 39.8 & 47.0 & 70.6 & 94.2 & 65.7 & 64.6 \\
\hline Imports (f.o.b.) & -74.5 & -88.1 & -132.1 & -176.3 & -137.2 & -135.1 \\
\hline Imports by emirates & -57.3 & -67.2 & -89.7 & -130.1 & -98.0 & -96.4 \\
\hline Free zones & -17.2 & -20.8 & -42.4 & -60.4 & -39.2 & -38.6 \\
\hline $\begin{array}{l}\text { Income, net } \\
\text { Government 2/ }\end{array}$ & $\begin{array}{l}3.1 \\
6.7\end{array}$ & $\begin{array}{l}5.8 \\
9.2\end{array}$ & $\begin{array}{r}7.9 \\
12.6\end{array}$ & $\begin{array}{l}3.1 \\
8.2\end{array}$ & $\begin{array}{l}1.5 \\
3.7\end{array}$ & $\begin{array}{l}2.4 \\
4.5\end{array}$ \\
\hline Services, net & -14.6 & -18.0 & -26.0 & -33.8 & -23.3 & -21.1 \\
\hline Transfers, net & -6.7 & -8.2 & -9.3 & -10.6 & -10.1 & -10.4 \\
\hline Private (incl. remittances) & -6.2 & -7.6 & -8.7 & -10.0 & -9.5 & -9.7 \\
\hline Official & -0.5 & -0.6 & -0.6 & -0.6 & -0.6 & -0.7 \\
\hline Financial account balance & -14.7 & -17.8 & 28.7 & -55.3 & 18.8 & -3.6 \\
\hline (in percent of GDP) & -11.0 & -10.8 & 13.8 & -21.2 & 8.1 & -1.4 \\
\hline Private capital & 15.0 & 22.1 & 59.2 & -25.8 & -9.2 & 8.5 \\
\hline Direct investment, net & 7.2 & 1.9 & -0.4 & -1.9 & -1.0 & -0.4 \\
\hline Portfolio flows, net & 6.1 & 1.2 & 1.4 & 2.2 & 2.5 & 2.6 \\
\hline Commercial banks & -3.4 & 9.7 & 48.6 & -12.2 & -11.0 & 4.0 \\
\hline Private non-banks and other & 5.1 & 9.3 & 9.6 & -13.7 & 0.3 & 2.2 \\
\hline Official capital & -29.7 & -39.9 & -30.1 & -32.4 & 28.0 & -12.0 \\
\hline Errors and omissions & -5.5 & -11.8 & 1.1 & -14.5 & -13.7 & -4.9 \\
\hline Overall balance & 2.5 & 6.6 & 49.9 & -46.9 & -1.1 & 9.6 \\
\hline Change in central bank net foreign assets & -2.5 & -6.6 & -49.9 & 46.9 & 1.1 & -9.6 \\
\hline \multicolumn{7}{|l|}{ Memorandum items: } \\
\hline Overall balance (percent of GDP) & 1.8 & 4.1 & 24.0 & -17.9 & -0.5 & 3.9 \\
\hline Gross reserves of central bank & 21.3 & 28.0 & 77.9 & 30.9 & 29.9 & 39.5 \\
\hline
\end{tabular}

Sources: U.A.E. authorities; and Fund staff estimates.

$1 /$ Not separately compiled; estimated at 40 to 70 percent of emirates imports.

2/ Estimate of investment income of sovereign wealth funds. 
Table 3. United Arab Emirates: Consolidated Government Finances, 2005-10 1/

\begin{tabular}{|c|c|c|c|c|c|c|}
\hline & 2005 & 2006 & 2007 & 2008 & $\frac{\text { Est. }}{2009}$ & $\frac{\text { Proj. }}{2010}$ \\
\hline & \multicolumn{6}{|c|}{ (In billions of U.A.E. dirhams) } \\
\hline Total revenue & 203.9 & 299.1 & 330.8 & 450.3 & 292.6 & 360.9 \\
\hline Hydrocarbon 2/ & 152.9 & 229.4 & 235.5 & 362.1 & 217.5 & 281.0 \\
\hline Nonhydrocarbon & 50.9 & 69.7 & 95.3 & 88.2 & 75.0 & 79.8 \\
\hline Customs & 3.9 & 4.6 & 8.0 & 6.5 & 5.9 & 5.8 \\
\hline Profit transfers & 4.6 & 8.0 & 13.0 & 17.0 & 17.7 & 18.0 \\
\hline Income tax 3/ & 0.4 & 0.6 & 0.8 & 1.2 & 1.0 & 1.0 \\
\hline Fees and charges & 8.8 & 13.6 & 9.7 & 12.2 & 12.7 & 13.0 \\
\hline Investment income 4/ & 24.6 & 33.7 & 46.3 & 30.2 & 18.3 & 22.2 \\
\hline Other & 8.6 & 9.3 & 17.3 & 21.0 & 19.5 & 19.8 \\
\hline Total expenditure and grants & 104 & 128 & 167 & 254 & 289 & 271 \\
\hline Current expenditure & 84.3 & 103.1 & 126.6 & 166.8 & 196.7 & 200.6 \\
\hline Wages and salaries $5 /$ & 15.9 & 17.7 & 21.3 & 29.0 & 33.6 & 35.1 \\
\hline Goods and services & 25.5 & 26.4 & 35.8 & 49.0 & 61.9 & 62.9 \\
\hline Abu Dhabi "federal services" 6/ & 22.8 & 25.3 & 31.3 & 45.6 & 56.2 & 57.2 \\
\hline Subsidies and transfers $7 /$ & 19.4 & 32.7 & 36.8 & 41.5 & 43.2 & 43.6 \\
\hline Other & 0.8 & 1.0 & 1.4 & 1.7 & 1.8 & 1.8 \\
\hline Development expenditure & 14.0 & 15.2 & 17.3 & 31.5 & 37.9 & 34.0 \\
\hline Loans and equity (net) $8 /$ & 5.1 & 9.0 & 20.8 & 51.8 & 52.1 & 34.5 \\
\hline Foreign grants $9 /$ & 1.0 & 0.4 & 2.3 & 3.6 & 2.4 & 2.4 \\
\hline Abu Dhabi & 1.0 & 0.4 & 2.1 & 3.5 & 2.3 & 2.4 \\
\hline Federal & 0.0 & 0.0 & 0.1 & 0.1 & 0.1 & 0.1 \\
\hline Overall balance (consolidated) & 99.5 & 171.4 & 163.8 & 196.6 & 3.5 & 89.4 \\
\hline Financing & -99.5 & -171.4 & -163.8 & -196.6 & -3.5 & -89.4 \\
\hline Bank financing, net & -16.0 & -4.6 & -9.5 & -26.6 & 72.9 & -26.3 \\
\hline \multirow[t]{2}{*}{ Nonbank financing } & -83.4 & -166.9 & -154.3 & -170.0 & -76.4 & -63.0 \\
\hline & \multicolumn{6}{|c|}{ (In percent of GDP) } \\
\hline Total revenue & 41.4 & 49.7 & 43.4 & 46.9 & 34.6 & 39.7 \\
\hline Of which: hydrocarbon & 31.0 & 38.2 & 30.9 & 37.7 & 25.7 & 30.9 \\
\hline Total expenditure and grants & 21.2 & 21.2 & 21.9 & 26.4 & 34.2 & 29.8 \\
\hline Current & 17.1 & 17.1 & 16.6 & 17.4 & 23.3 & 22.0 \\
\hline Development & 2.8 & 2.5 & 2.3 & 3.3 & 4.5 & 3.7 \\
\hline Overall balance (consolidated) & 20.2 & 28.5 & 21.5 & 20.5 & 0.4 & 9.8 \\
\hline Nonhydrocarbon balance & -10.9 & -9.6 & -9.4 & -17.2 & -25.3 & -21.1 \\
\hline \multirow[t]{2}{*}{ Nonhydrocarbon balance (excluding investment income) } & -15.9 & -15.3 & -15.5 & -20.4 & -27.5 & -23.5 \\
\hline & \multicolumn{6}{|c|}{ (In percent of nonhydrocarbon GDP) } \\
\hline Total revenue & 62.9 & 70.7 & 65.6 & 73.8 & 46.1 & 56.0 \\
\hline Of which: hydrocarbon & 47.2 & 54.2 & 46.7 & 59.3 & 34.3 & 43.6 \\
\hline Total expenditure and grants & 32.2 & 30.2 & 33.1 & 41.6 & 45.5 & 42.1 \\
\hline Current & 26.0 & 24.4 & 25.1 & 27.3 & 31.0 & 31.1 \\
\hline Development & 4.3 & 3.6 & 3.4 & 5.2 & 6.0 & 5.3 \\
\hline Overall balance (consolidated) & 30.7 & 40.5 & 32.5 & 32.2 & 0.6 & 13.9 \\
\hline Nonhydrocarbon balance & -16.5 & -13.7 & -14.2 & -27.1 & -33.7 & -29.7 \\
\hline Nonhydrocarbon balance (excluding investment income) & -24.1 & -21.7 & -23.4 & -32.1 & -36.6 & -33.2 \\
\hline \multicolumn{7}{|l|}{ Memorandum items: } \\
\hline Hydrocarbon share of revenue (in percent) & 75.0 & 76.7 & 71.2 & 80.4 & 74.4 & 77.9 \\
\hline
\end{tabular}

Sources: Federal government; Emirate finance departments; and staff estimates.

$1 /$ Consolidated accounts of the federal government, Abu Dhabi, Dubai and Sharjah.

2/ Includes staff estimates of revenues from other government entities operating in the hydrocarbon sector.

3/ Taxes on profit of foreign banks. Income taxes on gas companies are included under hydrocarbon revenues.

4/ Conservative estimates of transfers of earnings of sovereign wealth funds.

5/ Excludes military wages and salaries.

6/ Largely military and internal security expenditures paid by Abu Dhabi and not reflected in the federal fiscal accounts.

$7 /$ Includes government's contribution to the pension fund in 2005 of AED 6.2 billion, and direct transfers made by the office of Abu Dhabi's ruler in 2006 of about AED 8 billion.

8/ Includes 2006 purchase of telecom company (Etisalat) shares (AED 2 billion); part of which were divested following the IPO.

From 2006 onward, mainly Abu Dhabi's's equity and loans to its government-related enterprises.

9/ Intragovernmental grants are netted out in the consolidated fiscal accounts. 
Table 4. United Arab Emirates: Monetary Survey, 2005-10

\begin{tabular}{|c|c|c|c|c|c|c|}
\hline & 2005 & 2006 & 2007 & 2008 & $\begin{array}{c}\text { Prel. } \\
2009\end{array}$ & $\frac{\text { Proj. }}{2010}$ \\
\hline & \multicolumn{6}{|c|}{ (In billions of U.A.E. dirhams) } \\
\hline Net foreign assets & 167 & 156 & 160 & 33 & 70 & 90 \\
\hline Foreign assets & 253 & 335 & 483 & 317 & 329 & 375 \\
\hline Central Bank & 78 & 103 & 286 & 113 & 109 & 145 \\
\hline Commercial banks & 175 & 232 & 197 & 203 & 220 & 231 \\
\hline Foreign liabilities & 86 & 179 & 322 & 284 & 259 & 285 \\
\hline Central bank & 1 & 1 & 1 & 1 & 1 & 1 \\
\hline Commercial banks & 85 & 178 & 321 & 283 & 258 & 284 \\
\hline Net domestic assets & 157 & 244 & 405 & 641 & 670 & 696 \\
\hline Claims on government (net) & -47 & -52 & -61 & -85 & -12 & -38 \\
\hline Claims & 44 & 55 & 69 & 140 & 218 & 196 \\
\hline Deposits & 91 & 107 & 131 & 225 & 230 & 234 \\
\hline Claims on public sector enterprises & 25 & 33 & 45 & 56 & 76 & 80 \\
\hline Claims on private sector $2 /$ & 306 & 418 & 586 & 875 & 892 & 896 \\
\hline Capital and reserves (-) & -80 & -106 & -132 & -167 & -227 & -238 \\
\hline Other assets (net) & -46 & -50 & -32 & -38 & -59 & -3 \\
\hline Central Bank & -48 & -65 & -241 & -108 & -156 & -189 \\
\hline Commercial banks & 2 & 15 & 209 & 70 & 98 & 186 \\
\hline Of which: certificates of deposits & 21 & 32 & 174 & 47 & 70 & 123 \\
\hline Broad money (M2) & 324 & 399 & 566 & 674 & 740 & 786 \\
\hline Money & 104 & 120 & 182 & 208 & 230 & 244 \\
\hline Currency outside banks & 18 & 22 & 26 & 37 & 38 & 41 \\
\hline Dirham demand deposits & 87 & 98 & 156 & 171 & 191 & 204 \\
\hline \multirow[t]{2}{*}{ Quasi-money } & 220 & 279 & 384 & 466 & 510 & 542 \\
\hline & \multicolumn{6}{|c|}{ (Changes in percent of initial M2 stock) } \\
\hline Net foreign assets & 8.9 & -3.4 & 1.2 & -22.5 & 5.4 & 2.8 \\
\hline Central bank & 3.7 & 7.5 & 45.9 & -30.5 & -0.6 & 4.8 \\
\hline Commercial banks & 5.2 & -11.0 & -44.7 & 7.9 & 6.0 & -2.0 \\
\hline Net domestic credit & 36.7 & 35.9 & 42.8 & 48.8 & 16.2 & -2.5 \\
\hline Claims on government (net) & -6.6 & -1.4 & -2.4 & -4.2 & 10.8 & -3.6 \\
\hline Claims on public sector enterprises & 4.5 & 2.5 & 3.1 & 1.9 & 2.9 & 0.5 \\
\hline \multirow[t]{2}{*}{ Claims on private sector $3 /$} & 38.9 & 34.7 & 42.0 & 51.1 & 2.5 & 0.6 \\
\hline & \multicolumn{6}{|c|}{ (Changes in percent; unless otherwise indicated) } \\
\hline Claims on private sector & 44.5 & 36.9 & 40.1 & 49.3 & 1.9 & 0.5 \\
\hline Broad money (M2) & 33.8 & 23.2 & 41.7 & 19.2 & 9.7 & 6.3 \\
\hline Money & 29.2 & 14.9 & 51.4 & 14.6 & 10.3 & 6.3 \\
\hline Quasi Money & 36.0 & 27.2 & 37.5 & 21.4 & 9.4 & 6.3 \\
\hline Velocity (non-oil GDP/M2) & 1.00 & 1.06 & 0.89 & 0.90 & 0.86 & 0.82 \\
\hline Base money & 14.2 & 22.3 & 70.0 & 32.2 & 10.7 & 5.7 \\
\hline Money multiplier (M2/base money) & 7.3 & 7.4 & 6.1 & 5.5 & 5.5 & 5.5 \\
\hline
\end{tabular}

Sources: Central Bank of the U.A.E., and Fund staff estimates.

$1 /$ Including nonbank financial institutions 
Table 5. United Arab Emirates: Medium-Term Baseline Scenario, 2010-15

\begin{tabular}{|c|c|c|c|c|c|c|}
\hline & \multicolumn{6}{|c|}{ Proj. } \\
\hline & 2010 & 2011 & 2012 & 2013 & 2014 & 2015 \\
\hline Crude oil production (millions of barrels per day) $1 /$ & 2.80 & 2.95 & 3.08 & 3.20 & 3.32 & 3.44 \\
\hline Crude oil exports (millions of barrels per day) $1 /$ & 2.20 & 2.32 & 2.43 & 2.52 & 2.61 & 2.71 \\
\hline \multirow[t]{2}{*}{ Average U.A.E. oil export price (in U.S. dollars/barrel) } & 75 & 81 & 84 & 86 & 87 & 88 \\
\hline & \multicolumn{6}{|c|}{ (Percentage change, except as noted) } \\
\hline Nominal GDP (in billions of U.S. dollars) & 247.7 & 266.3 & 289.0 & 313.3 & 339.8 & 369.2 \\
\hline Real GDP (at factor cost) & 0.6 & 3.1 & 4.0 & 4.4 & 4.7 & 4.8 \\
\hline Hydrocarbon & 2.7 & 5.7 & 4.7 & 3.8 & 3.8 & 3.8 \\
\hline Nonhydrocarbon & 0.0 & 2.3 & 3.8 & 4.6 & 5.0 & 5.0 \\
\hline \multirow[t]{2}{*}{ Consumer prices (annual average) } & 1.5 & 2.5 & 3.5 & 3.4 & 3.3 & 3.2 \\
\hline & \multicolumn{6}{|c|}{ (In percent of GDP) } \\
\hline National saving & 27.1 & 27.2 & 29.6 & 30.8 & 30.2 & 30.6 \\
\hline Government & 30.2 & 33.3 & 34.8 & 35.3 & 35.4 & 35.1 \\
\hline Non-government & -3.1 & -6.1 & -5.3 & -4.6 & -5.2 & -4.5 \\
\hline Gross domestic investment & 19.8 & 19.5 & 18.9 & 18.6 & 18.2 & 18.5 \\
\hline Government & 9.5 & 9.2 & 9.0 & 8.8 & 8.7 & 8.6 \\
\hline \multirow[t]{2}{*}{ Nongovernment } & 10.3 & 10.2 & 10.0 & 9.8 & 9.6 & 9.8 \\
\hline & \multicolumn{6}{|c|}{ (In percent of GDP) } \\
\hline \multicolumn{7}{|l|}{ Consolidated fiscal accounts } \\
\hline Revenue & 39.7 & 42.5 & 43.8 & 44.1 & 44.0 & 43.8 \\
\hline Hydrocarbon & 30.9 & 32.8 & 32.8 & 32.1 & 31.1 & 30.3 \\
\hline Non-hydrocarbon & 8.8 & 9.7 & 11.0 & 12.1 & 13.0 & 13.5 \\
\hline Of which: Investment income & 2.4 & 3.5 & 4.7 & 5.7 & 6.6 & 7.0 \\
\hline Expenditure and net lending & 29.8 & 29.1 & 28.8 & 28.8 & 29.0 & 28.7 \\
\hline Current & 22.0 & 21.5 & 21.4 & 21.4 & 21.6 & 21.6 \\
\hline Capital & 3.7 & 3.6 & 3.5 & 3.5 & 3.4 & 3.4 \\
\hline Overall balance & 9.8 & 13.5 & 15.0 & 15.3 & 15.1 & 15.1 \\
\hline \multirow[t]{2}{*}{ Nonhydrocarbon balance 2/ } & -29.7 & -27.9 & -25.8 & -24.0 & -22.6 & -21.3 \\
\hline & \multicolumn{6}{|c|}{ (In percent of GDP) } \\
\hline \multicolumn{7}{|l|}{ External accounts } \\
\hline Exports & 73.6 & 77.4 & 76.3 & 74.9 & 71.9 & 69.2 \\
\hline Imports, f.o.b. & -54.5 & -58.2 & -56.3 & -54.7 & -53.2 & -51.4 \\
\hline Services (net) & -8.5 & -9.1 & -8.3 & -8.1 & -7.9 & -7.4 \\
\hline Investment income (net) & 1.0 & 1.9 & 3.1 & 4.2 & 5.1 & 5.7 \\
\hline Transfers (net) & -4.2 & -4.2 & -4.1 & -4.0 & -4.0 & -3.9 \\
\hline Current account balance (in billions of U.S. dollars) & 18.1 & 20.6 & 30.8 & 38.2 & 40.5 & 44.9 \\
\hline Current account balance & 7.3 & 7.7 & 10.7 & 12.2 & 11.9 & 12.2 \\
\hline Overall balance & 3.9 & 4.0 & 5.2 & 4.1 & 4.4 & 4.1 \\
\hline Central bank reserves & 16.0 & 18.9 & 22.6 & 25.0 & 27.5 & 29.4 \\
\hline In months of next year imports of goods and services & 2.4 & 3.0 & 3.7 & 3.7 & 3.7 & 3.7 \\
\hline External debt $3 /$ & 56.4 & 56.5 & 56.2 & 55.9 & 55.6 & 55.3 \\
\hline
\end{tabular}

Sources: U.A.E. authorities; and Fund staff estimates and projections.

$1 /$ Includes condensates, which are not subject to the OPEC quota.

2/ In percent of non-hydrocarbon GDP.

3/ Mostly foreign liabilities of banking system; incomplete coverage of debt raised by non-banks in the international markets. 
Table 6. United Arab Emirates: Selected Indicators of External Vulnerability, 2005-08

\begin{tabular}{|c|c|c|c|c|}
\hline & 2005 & 2006 & 2007 & 2008 \\
\hline \multicolumn{5}{|l|}{ External solvency indicators } \\
\hline REER (CPI-based, percent change, annual average) & 2.5 & 5.4 & 2.4 & 3.7 \\
\hline Total external debt (in billions of U.S. dollars) & 41.0 & 80.6 & 130.1 & 135.8 \\
\hline Total external debt/GDP (percent) & 30.6 & 49.2 & 62.7 & 52.0 \\
\hline \multicolumn{5}{|l|}{ Public sector solvency indicators (in percent) } \\
\hline Overall fiscal balance/GDP & 20.2 & 28.5 & 21.5 & 20.5 \\
\hline Government domestic debt/GDP & 9.2 & 10.1 & 9.7 & 15.1 \\
\hline Oil revenue/total revenue & 75.0 & 76.7 & 71.2 & 80.4 \\
\hline Investment income/total revenue & 12.1 & 11.3 & 14.0 & 6.7 \\
\hline Non-oil revenue (excl. investment income)/non-oil GDP & 8.1 & 8.5 & 9.7 & 9.5 \\
\hline Non-oil balance/GDP & -10.9 & -9.6 & -9.4 & -17.2 \\
\hline \multicolumn{5}{|l|}{ External liquidity indicators } \\
\hline Central bank foreign assets (in millions of U.S. dollars) & 21,280 & 27,958 & 77,855 & 30,949 \\
\hline In months of imports of goods and services & 2.3 & 2.0 & 4.3 & 2.2 \\
\hline As percent of M1 & 74.8 & 85.5 & 157.4 & 54.6 \\
\hline As percent of commercial banks foreign liabilities & 91.7 & 57.8 & 89.1 & 40.2 \\
\hline Commercial banks' NFA (in millions of U.S. dollars) & 24,456 & 14,772 & $-33,784$ & $-21,569$ \\
\hline Foreign assets & 47,659 & 63,155 & 53,614 & 55,381 \\
\hline Foreign liabilities & 23,204 & 48,383 & 87,398 & 76,950 \\
\hline Crude oil exports/total exports (in percent) & 36.6 & 39.0 & 34.2 & 35.6 \\
\hline \multicolumn{5}{|l|}{ Financial sector indicators } \\
\hline Foreign currency deposits/total deposits (in percent) & 24.1 & 25.5 & 16.9 & 18.9 \\
\hline Net domestic assets (annual change in percent) & 62.2 & 54.9 & 66.3 & 58.2 \\
\hline Private sector credit (annual change in percent) & 44.5 & 36.9 & 40.1 & 49.3 \\
\hline Private credit/total assets of banks (in percent) & 50.2 & 50.7 & 49.8 & 62.7 \\
\hline Interest rate spread against U.S. dollar (in basis points) $1 /$ & 18 & -20 & -81 & 124 \\
\hline \multicolumn{5}{|l|}{ Banking system indicators (in percent) $2 /$} \\
\hline Commercial banks' capital to risk-weighted assets ratio & 17.4 & 16.6 & 14.0 & 13.3 \\
\hline Gross non-performing loans to total loans & 8.3 & 6.3 & 2.9 & 2.5 \\
\hline Return on assets & 2.7 & 2.3 & 2.0 & 2.3 \\
\hline Return on equity & 22.5 & 18.0 & 19.3 & 21.1 \\
\hline
\end{tabular}

Sources: U.A.E. authorities; and IMF staff estimates.

1/ Spread between 28-day CBU CD and 1-month \$LIBOR, exc. 2009, EIBOR less LIBOR. 2/ Data in 2008 column correspond to values as of end-June 2008. 
Table 7. United Arab Emirates: Financial Sector Indicators, 2005-09 1/

(In percent, unless otherwise indicated)

\begin{tabular}{|c|c|c|c|c|c|c|}
\hline & 2005 & 2006 & 2007 & $\frac{\text { June }}{2008}$ & $\frac{\text { June }}{2009}$ & $\frac{\text { Nov }}{2009}$ \\
\hline \multicolumn{7}{|l|}{ Core indicators } \\
\hline \multicolumn{7}{|l|}{ Deposit-taking institutions $2 /$} \\
\hline Total regulatory capital to risk-weighted assets & 17.4 & 16.6 & 14.0 & 13.3 & 17.8 & 18.6 \\
\hline Regulatory Tier I capital to risk-weighted assets & 16.9 & 15.0 & 12.4 & 11.9 & 15.4 & 15.4 \\
\hline Nonperforming loans net of provisions to capital & 1.8 & 0.6 & 0.0 & 0.0 & 6.0 & 10.1 \\
\hline Nonperforming loans to total gross loans & 8.3 & 6.3 & 2.9 & 2.5 & 3.0 & 4.6 \\
\hline Return on assets & 2.7 & 2.3 & 2.0 & 2.3 & 1.8 & 1.5 \\
\hline Return on equity & 22.5 & 18.0 & 19.3 & 21.1 & 15.9 & 12.1 \\
\hline Interest margin to gross income & 49.3 & 29.3 & 32.4 & 37.7 & 67.8 & 66.0 \\
\hline Noninterest expenses to gross income & 26.9 & 20.9 & 21.4 & 24.4 & 34.7 & 34.3 \\
\hline Liquid assets to total assets & 26.9 & 16.4 & 13.2 & 8.6 & 16.8 & 18.5 \\
\hline Liquid assets to short-term liabilities & .. & .. & .. &.. & 97.3 & 104.3 \\
\hline \multicolumn{7}{|l|}{ Encouraged indicators } \\
\hline \multicolumn{7}{|l|}{ Deposit-taking institutions 2/ } \\
\hline Capital to assets & 11.9 & 12.6 & 15.5 & 11.0 & 11.1 & 12.6 \\
\hline Loan loss reserves/non-performing loans & 95.7 & 98.2 & 100.0 & 101.5 & 99.1 & 79.0 \\
\hline Customer deposits to total (non-interbank) loans & 112.4 & 96.5 & 99.7 & 93.7 & 88.2 & 90.0 \\
\hline \multicolumn{7}{|l|}{ Households } \\
\hline Household debt to GDP & 6.9 & 5.2 & 6.0 & .. & .. & . \\
\hline Commercial real estate loans to total loans & 5.0 & 5.9 & 8.3 & 10.0 & 10.8 & 11.5 \\
\hline Residential real estate to total loans & .. & .. & .. &.. & 7.9 & 10.4 \\
\hline \multicolumn{7}{|l|}{ Other indicators 3/ } \\
\hline Deposits as percent of M2 4/ & 126.7 & 130.3 & 127.0 & 123.9 & 122.1 & 123.3 \\
\hline Number of commercial banks (end-of-period) & 46 & 46 & 48 & 50 & 50 & 50 \\
\hline Number of banks with C.A.R. above 10 percent & 46 & 46 & 48 & 50 & 50 & 50 \\
\hline Foreign currency deposits as percent of M2 & 22.8 & 24.1 & 16.1 & 15.5 & 16.6 & 17.2 \\
\hline Earning per employee (in millions of AED) & 0.7 & 0.7 & 0.8 & 0.9 & 0.8 & 0.7 \\
\hline
\end{tabular}

Source: Central Bank of the United Arab Emirates.

$1 /$ Starting in 2009, based on direct reporting system. Not fully consistent with reporting system of earlier years. 2/ National banks only.

3/ All resident deposit-taking institutions as defined in the monetary survey.

4/ Deposits include deposits of nonresident nonbanks and government deposits. 


\section{AnNex. The U.A.E. Federation AND the Dubai Debt Situation}

1. The U.A.E. is a federation of seven emirates formed in 1971. The Ruler of Abu Dhabi is President of the Federation, and the Ruler of Dubai is Vice-President and Prime Minister of the Federal Government (FG). The constitution gives each emirate autonomy over its economic policies, laws, and natural resources. Some functions of government are shared at the federal level, such as defense, foreign policy, and central banking. The FG's budget functions largely as a vehicle for transferring resources from Abu Dhabi and Dubai to the other emirates in order to ensure that basic public goods and services (e.g., transportation, health, and education) are of similar standards across the U.A.E. The richest emirates are Abu Dhabi (50 percent of GDP), Dubai (30 percent), and Sharjah ( 8 percent). Sharjah City is adjacent to Dubai City and fully integrated with it.

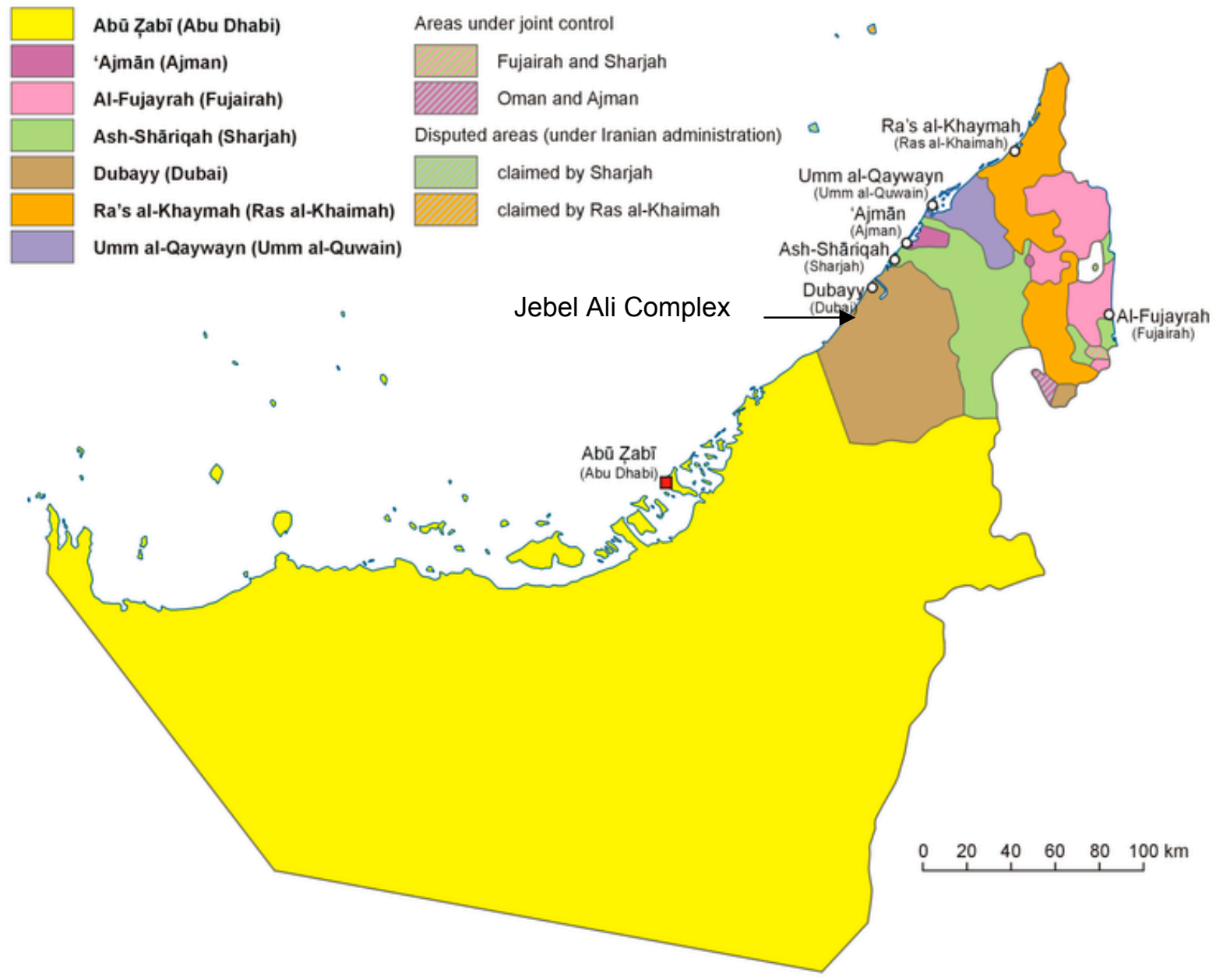

\section{The Emirate of Abu Dhabi controls 95 percent of the U.A.E.'s hydrocarbon} wealth and has substantial external financial assets. Abu Dhabi (AD) is the world's $5^{\text {th }}$ largest exporter of crude oil and holds the $7^{\text {th }}$ largest reserves of natural gas. Each AD national has an imputed $\$ 50$ million worth of below-ground hydrocarbon reserves, as well as $\$ 600,000$ of above-ground sovereign financial wealth. The AD Investment Authority (ADIA) 
is among the world's largest Sovereign Wealth Funds (SWF), valued at a minimum of two times the AD GDP. ${ }^{1}$ ADIA's mandate since inception in 1977 is to invest overseas the proceeds of AD's hydrocarbon exports in a broadly neutral manner. ADIA's portfolio is globally diversified along the lines of Norway's Government Pension Fund-Global.

\section{After decades of investing abroad, Abu Dhabi started only recently to invest its} hydrocarbon wealth into the local economy. Starting around 2007, AD deployed smaller funds/sovereign wealth enterprises (SWE) with mandates to diversify the AD's economy, while keeping ADIA focused on investing abroad. The SWEs obtained equity and loans from the $\mathrm{AD}$ government to finance massive investments into local infrastructure, real estate, hospitality, advanced manufacturing, and supporting services. This new growth engine adds significantly to AD's traditional oil engine and to non-oil activity in the U.A.E. as a whole. AD's SWEs have also become significant issuers in the international capital markets.

\section{The Emirate of Dubai has historically been the most dynamic and integrated} internationally, following Singapore as a model. Dubai has been a trading port on the Asia-Europe route since the $19^{\text {th }}$ century - the Indian rupee was legal tender in Dubai before WWII. The small Fateh oil field was discovered off-shore Dubai in the 1960s. Proceeds from Fateh were invested locally, mainly to build the Jebel Ali Port complex which has since become the world's fourth largest seaport after Singapore. The complex also hosts Dubai Aluminum, among the world's largest smelters and another example of the diversification drive of the 1970s. Emirates Airlines, Jumeirah (hotels), Emaar Properties, and Dubai Ports World (DP World) were launched in the 1980s and 1990s with a view to further emulating Singapore's diversification success.

\section{A new diversification push into commercial and residential real estate came} around 2004 following the decision to allow foreigners to own property in designated areas. By 2008, Dubai had become an attractive location for global companies serving the regional market and for secondary/retirement homes of wealthy individuals living in an arc of 4-6 hours flight time to Dubai's large airport. Accordingly, the economy now revolves around two core growth engines: global hubbing (logistics, business services, and tourism) and construction/property, with 90 percent of Dubai's population being expatriates.

6. Dubai Inc. dominates the economy of Dubai (Annex Box 1). Dubai Inc. is a network of commercial companies and investment arms owned directly or related closely to the Ruler of Dubai, his family, or the Government of Dubai (GD). At its simplest, Dubai Inc. consists of three holding companies, Dubai Holding (owned by the Ruler), Dubai World, and the Investment Corporation of Dubai (both owned by the GD). A few other companies are owned jointly. Each holding is present in Dubai's growth engines and this overlap has

\footnotetext{
1 ADIA does not disclose assets under management. Two times GDP is information provided by the AD government to rating agencies. The Emirate of Abu Dhabi as sovereign issuer is rated AA or equivalent.
} 
fostered competition as well as duplication. Each holding has choice assets with solid earnings, as well as start-ups requiring large amounts of capital upfront, particularly in property. ${ }^{2}$ Dubai's private companies are mostly owned by old merchant families. The private sector is fairly small and dependent on Dubai Inc.'s business.

7. Dubai Inc.'s three holding companies each have real estate businesses. These businesses are mostly master developers of land granted to them by the GD. They sell developed land plots further down the chain to local developers for marketing to retail investors. They also build and manage properties themselves. Intense competition has led to mega-projects, such as Emaar's world's tallest tower or Nakheel's Palm and World reclaimed islands, fuelled by short-term debt and benign conditions prevailing in the global capital market. By the time the global financial crisis broke out, Emaar (part-owned by ICD) was already a mature company with most projects sold, but Nakheel (a DW property developer) or the developers of Dubai Holding, were not. Extensive leverage also fed overseas investments and private equity ventures, principally within Dubai Holding and DW, and at the top of the market.

\section{DW's real estate interests are concentrated in Nakheel Properties, Limitless} World, and Istithmar World. Nakheel's focus is Dubai; Limitless World, a more recent company, has comparatively more overseas real estate ventures; and Istithmar World is an investment arm with several overseas property-related interests. Although consolidated financials of Dubai World are not public, Nakheel and Limitless likely constitute about half of Dubai World's assets, the rest being held mainly by DP World, JAFZ, and Istithmar. Nakheel's remaining interests in overseas properties were transferred to Istithmar in September 2008.

\section{Dubai Inc. boosted borrowing sharply during 2004-08 to fund a new push into} commercial and residential property. Both foreign and local banks allowed Dubai Inc. to increase leverage. Liabilities to global banks as a ratio to GDP were at similar levels to Singapore in 2004, but this ratio became some two times higher by mid-2008. The increase in foreign indebtedness took mainly the form of short-term debt. In addition to foreign borrowing, domestic credit growth during 2004-08 was among the fastest in emerging markets. In this period, the local banks generated about $\$ 100$ billion of credit above that expected from underlying trend credit growth.

\footnotetext{
2 Dubai Inc.'s flagship companies are the Jumeirah Hotels (Dubai Holding), DP World (Dubai World) and Emirates Airlines and Dubal (ICD).
} 
Annex Box 1. Dubai Inc.

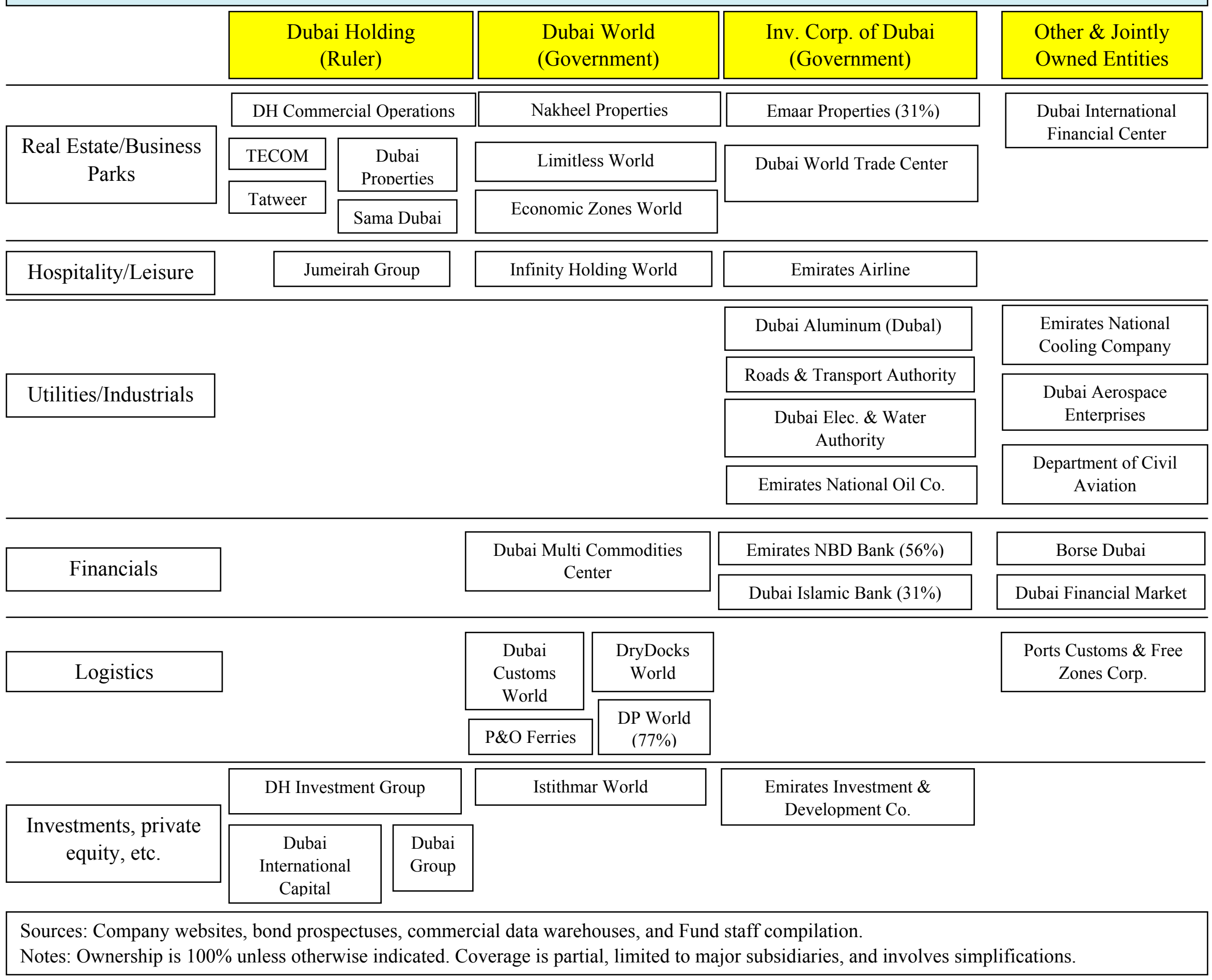




\section{Foreign Borrowing and Domestic Credit Growth}

Ratio: liabilities to BIS banks/non-oil GDP (Index, 2005Q2 = 100)
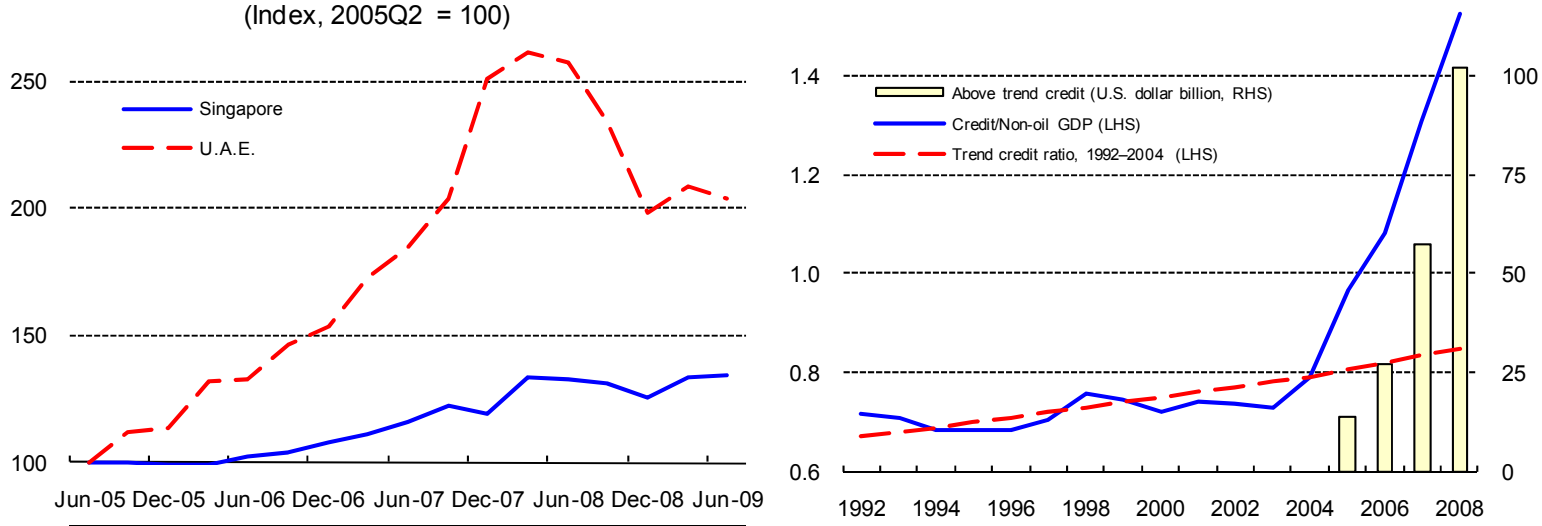

Sources: BIS Consolidated Banking Statistics; WEO; and Fund staff calculations.

10. The bursting of Dubai's real estate bubble in mid-2008 and the post-Lehman shutdown of capital markets increased investor concerns about Dubai's ability to service its debt. By early 2009, Dubai was still able to roll over, sometimes partially, the debt falling due (Annex Box 2). However, there was consensus that the key test would be the Nakheel 09 sukuk maturing December 14, because of its size (\$4 billion, including interest) for a company with limited earnings.

\section{Investor concerns eased substantially when the GD announced a \$20 billion} support program for Dubai in February 2009. The GD sold the first $\$ 10$ billion tranche to the central bank of the U.A.E. in March 2009. Although Abu Dhabi was not formally involved, the fact that the central bank as a federal institution fully subscribed the bonds was taken as a signal that Abu Dhabi would help Dubai Inc. service its debt. By September, the Nakheel 09 had risen above par, from 60 at the height of market concern in 2009Q1. ${ }^{3}$

\section{In July 2009, the GD set up the Dubai Financial Support Fund (DSF) to manage} the \$20 billion package, as part of a broad push to restructure Dubai Inc. (Annex Box 3). The DSF's stated aim is to provide assistance on arm's-length terms to Dubai Inc. strategic entities that require temporary financial assistance but can otherwise demonstrate sustainable business plans, the ongoing support of creditors, and realistic prospects of fulfilling their repayment obligations, including to the DSF. Between March 2009 and the formal establishment of the DSF in July 2009, the GD had already provided support to some strategic entities for critical contractual payments and to protect Dubai's economy and supply chain. The DSF acquired these loans and amended as needed the relevant agreements. The DSF is funded by securities issued by the GD. Although the securities are obligations of the GD, the DSF is expected to service the securities from its own resources, hence its extra-budgetary nature.

\footnotetext{
${ }^{3}$ Trading above par reflected the fact that the Nakheel 09 would also pay half of the interest at maturity. The accumulated interest was one feature of the Islamic nature of the structure.
} 


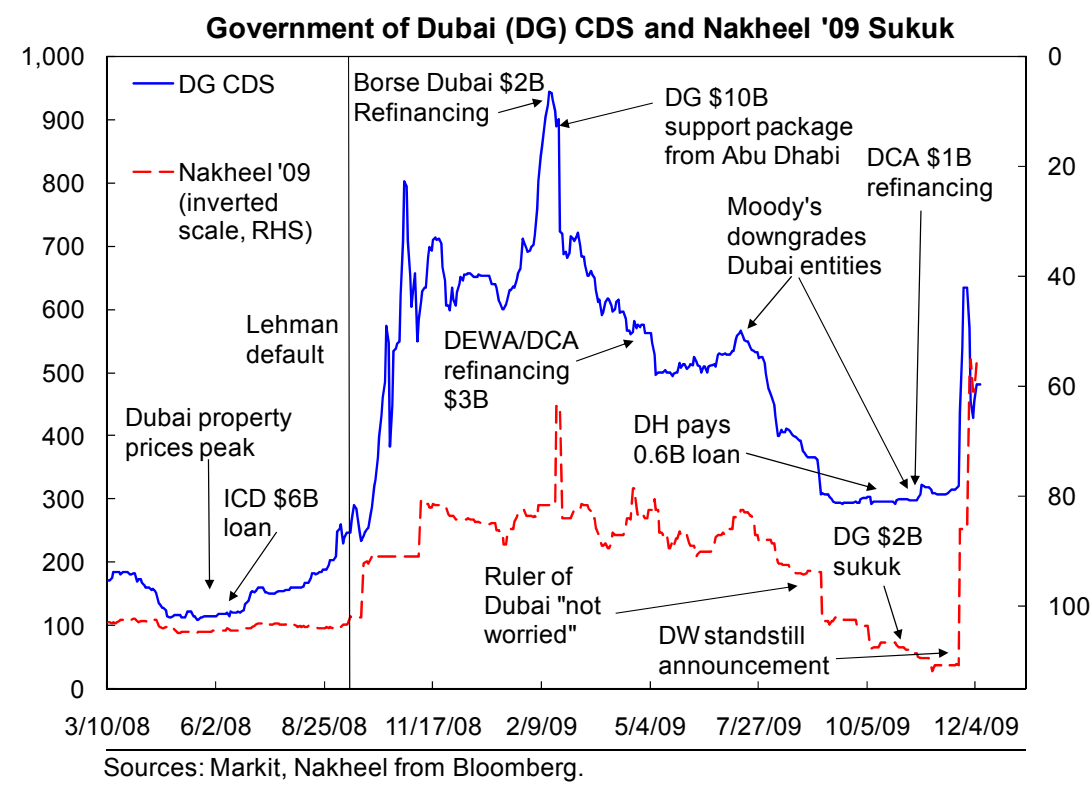

Annex Box 2. Dubai World Debt Standstill: Timeline

2002: Dubai allows foreigners to buy property via 99-yr leases in designated areas

2004: beginning of bubble conditions in credit (foreign and domestic) and property

2008:

May: Gov. of Dubai (GD) launches $\$ 4$ billion foreign and local currency MTN program

June: Investment Corporation of Dubai's (ICD) syndicated "Islamic" loan ( $\$ 6$ billion), guaranteed by GD

Mid-year: Dubai property prices peak; DW subsidiary Emaar completes construction of world's tallest tower

2009:

February: partial refinancing of loan (\$2 billion) to ICD subsidiary Borse Dubai; ICD provides balance.

Nakheel 09 sukuk trades at 60 cents on the dollar

February: GD announces $\$ 20$ billion support program; first $\$ 10$ billion to be subscribed by central bank

March: GD sells $\$ 10$ billion bond to central bank of U.A.E.

April: DEWA and Dubai Civil Aviation refinance $\$ 3$ billion through sukuk and 18-bank syndicate

June 30: Moody's downgrades the six Dubai Inc. issuers it rates

September 10: DW announces talks with core banks to reschedule $\$ 12$ billion of debt, including Nakheel September 17: Nakheel's overseas property portfolio transferred to Istithmar World, subsidiary of DW

October 15: DW cuts $15 \%$ of 70,000 staff to save $\$ 800$ million over three years

October 28: GD issues $\$ 2$ billion sukuk foreign and local currency, 3 times oversubscribed, largest in Gulf

November 4: Moody's again downgrades Dubai Inc. issuers

November 25: GD issues $\$ 5$ billion bond to two government-controlled Abu Dhabi banks. Two hours later,

GD announces that DW asks for 6-month standstill to restructure \$26 billion

December 8: Moody's downgrades all Dubai issuers to non-investment grade

December 14: Abu Dhabi extends further $\$ 5$ billion to GD to pay Nakheel 09 fully and on time

December 21: DW holds first meeting with steering committee of bank creditors 


\section{Annex Box 3. The Dubai Financial Support Fund (DFSF)}

The DSF is an extra budgetary fund of the GD's Department of Finance (DoF) established in July 2009. Its chairman is the Director of the DoF.

\section{Objectives}

- support strategic entities critical for Dubai's economy and supply chain;

- maximize the impact of its capital;

- deliver an appropriate risk-weighted return on capital employed; and

- establish an optimal reporting regime that supports its financial objectives.

\section{Terms and conditions}

Applicant entities must submit detailed past, current and forecast financial and operational information; comprehensive business plans explaining how operational or financial shortcomings support are addressed; and a detailed and substantiated explanation of how debt, including any provided by DSF, will be serviced and repaid.

Independent investment advisors appointed by DSF review this information to test the viability of the business plans; negotiate the nature, terms and extent of support; and agree revisions where necessary. On the basis of this due diligence, the advisors make recommendations to DSF management on the extent, terms, and conditions of support, adequate security, payment of interest or dividends, financial and operational covenants, reporting obligations, management observation and step-in rights.

At disbursement, procedures are agreed to monitor performance and report progress.

\section{Funding}

The DSF is funded through the proceeds of dollar-denominated securities issued by the GD under a $\$ 20$ billion 5-year unsecured program with the following tranches:

- First tranche, announced March 2009: $\$ 10$ billion from the CBU, coupon of 4 percent per annum or the rate on the U.S. 5-year Treasury Note plus 0.10 per cent per annum (whichever is higher);

- $\quad$ Second tranche, announced November 2009: \$5 billion from two Abu Dhabi banks, half conventional, half Islamic, similar terms;

- Third tranche, announced December 2009: $\$ 5$ billion from Abu Dhabi government, similar terms. The second and third tranches have not yet been fully disbursed.

Source: Government of Dubai.

13. Markets were surprised in November 2009 when GD announced that Dubai World would seek a 6-month standstill on debt related to its real estate businesses as a prelude to their restructuring. After several days of dislocation compounded by thin holiday trading, markets settled into a new pattern of sharp differentiation between Dubai entities with strong cash flows or explicit government guarantees, and other entities. With Nakheel's debt included in the announcement, bondholders read more carefully the prospectus of the Nakheel 09 sukuk maturing in December, and concluded that the complexity of the structure could hinder investor recourse to Nakheel or DW assets.

\section{Abu Dhabi stepped in shortly thereafter to prevent the disruption that a default} would have meant for the economy of the U.A.E. and its banking system. The government extended a $\$ 5$ billion loan to the GD in order to pay the Nakheel 09 in full and on time. In announcing the transaction, Abu Dhabi stressed that support for Dubai entities is 
and will remain selective and on a case-by-case basis. It is generally agreed that without significant debt restructuring, Nakheel is unlikely to be a sustainable business (e.g., the Nakheel 10 and 11 are trading at around 50-60 cents on the dollar). In supporting an entity under financial duress, Abu Dhabi was signaling its intention to limit contagion to the U.A.E. economy and banking system.

15. The restructuring of $\mathrm{DW}$ is complicated because this holding company has dozens of subsidiaries, participations and interests, both locally and around the world (Annex Box 4). The GD appointed a chief restructuring officer (CRO) [Deloitte LLC] to go through its accounts with a view to triage the businesses according to their needs for operational restructuring and balance sheet restructuring. At this stage, the CRO's focus is on the group's real estate operations and interests. However, the CRO will also need to determine whether assets of the healthy parts of DW will also be included in the restructuring process.

\section{Neither DW nor Dubai Inc. discloses consolidated balance sheet or debt}

information. There are no official statistics, and it is difficult to build them from company financials because the majority of Dubai Inc. entities do not disclose financials, except to their bankers. Documentation in the public domain covers only syndicated loans and bonds as captured by various data providers, and analysts' estimates are based on these sources. As such, the estimates are of publicly-held debt and therefore exclude (i) syndicated loans for which documentation is incomplete; (ii) bilateral loans (from global or local banks); (iii) accounts payables/suppliers' credits; and (iv) derivatives, credit commitments, and other liabilities. Staff's estimate of Dubai publicly-held debt is contained in Annex Table 1. Dubai Inc. debt on this preliminary basis would be on the order of $\$ 85$ billion, of which $\$ 8$ billion corresponds to foreign notes and bonds issued by banks controlled by Dubai Inc. The GD would have direct debt of $\$ 24$ billion, giving a total of $\$ 109$ billion (about 130 percent of Dubai GDP). Within this total, GD and GD-guaranteed debt is about $\$ 35$ billion (40 percent of Dubai GDP).

17. Information on debt within the DW standstill perimeter has become clearer than on debt of DW's consolidated or Dubai Inc.'s debt. At this time, and after the payment of the Nakheel 09, the standstill perimeter is about \$22 billion (in local and foreign currencies), of which $\$ 12$ billion is in the form of syndicated loans, $\$ 7.5$ billion corresponds to bilateral loans and $\$ 2.5$ billion to bonds. The share held by national banks is 45 percent of the total ( $\$ 10$ billion), of which $2 / 3$ is to Dubai-based banks (6 percent of their book) and $1 / 3$ to Abu Dhabi banks ( 3 percent of their book). The national banks also hold 80 percent of the Nakheel 10 and 11 sukuk bonds. The debt subject to negotiation is owed by Nakheel, Limitless, and by DW at the holding company level (DW Holding, DW Group Finance), the largest component being at the holding company level. The extent and form of the needed debt restructuring will become clearer as the negotiations between DW and its creditors progress. 
Annex Box 4. Dubai World, partial listing of key subsidiaries and participations

\begin{tabular}{|c|c|c|}
\hline & Country & Holding \\
\hline \multicolumn{3}{|l|}{ Subsidiaries } \\
\hline DryDocks World & U.A.E. & $100 \%$ \\
\hline Drydocks World Dubai & U.A.E. & $100 \%$ \\
\hline Afloat Repair Division & U.A.E. & \\
\hline Drydocks World Dubai Shiplift & U.A.E. & \\
\hline Drydocks World Singapore & Singapore & $100 \%$ \\
\hline Drydocks World Southeast Asia & Singapore & $100 \%$ \\
\hline Labroy Marine & Indonesia & $100 \%$ \\
\hline Palm Marine & U.A.E. & $100 \%$ \\
\hline PT Batam Maritime Center & Indonesia & $80 \%$ \\
\hline Polarcus & U.A.E. & $47 \%$ \\
\hline Drydocks World - Graha & Indonesia & \\
\hline Dubai Maritime City & U.A.E. & $100 \%$ \\
\hline Dubai Agricultural World & U.A.E. & $100 \%$ \\
\hline Dubai Energy World & U.A.E. & $100 \%$ \\
\hline Dubai Mining World & U.A.E. & $100 \%$ \\
\hline Dubai Multi Commodities Center & U.A.E. & $100 \%$ \\
\hline Dubai Commodity Asset Management & U.A.E. & $100 \%$ \\
\hline Dubai Cotton Center & U.A.E. & $100 \%$ \\
\hline Dubai Diamond Exchange & U.A.E. & $100 \%$ \\
\hline Dubai Tea Trading Center & U.A.E. & $100 \%$ \\
\hline Dubai Gold and Commodities Exchange & U.A.E. & $51 \%$ \\
\hline Dubai Commodities Clearing Corporation & U.A.E. & $100 \%$ \\
\hline Dubai Shariah Asset Management & U.A.E. & $51 \%$ \\
\hline Dubai Gems Club & U.A.E. & - \\
\hline Dubai Pearl Exchange & U.A.E. & - \\
\hline Polygon DMCC & U.A.E. & - \\
\hline Dubai Natural Resources World & U.A.E. & $100 \%$ \\
\hline Dubai World Africa & South Africa & $100 \%$ \\
\hline Dubai World Security & U.A.E. & $100 \%$ \\
\hline Economic Zones (EZ) World & U.A.E. & $100 \%$ \\
\hline Business Centers World & U.A.E. & $100 \%$ \\
\hline Dubai Auto Zone & U.A.E. & $100 \%$ \\
\hline Gazeley & United Kingdom & $100 \%$ \\
\hline Jebel Ali Free Zone (JAFZA) & U.A.E. & $100 \%$ \\
\hline Jafza Americas & United States & $100 \%$ \\
\hline Techno Park & U.A.E. & $100 \%$ \\
\hline EZ Post FZCO & U.A.E. & $51 \%$ \\
\hline Dubai Cars and Automotive Zone & U.A.E. & - \\
\hline Dubai Textile City & U.A.E. & - \\
\hline Business and Logistics Park & India & - \\
\hline Dakar International Special Economic Zone & Senegal & - \\
\hline Djibouti Free Zone & Djibouti & - \\
\hline Martime Center & Malaysia & - \\
\hline Medhub & Morocco & - \\
\hline Misurata Free Zone [MFZ] & Libya & - \\
\hline
\end{tabular}


Annex Box 4. Dubai World, partial listing of key subsidiaries and participations

\begin{tabular}{lcc}
\hline & Country & Holding \\
\hline Orangeburg & United States & - \\
Rakista Economic City & Saudi Arabia & - \\
Salalah Port & Oman & - \\
Subic Bay Freeport & Philippines & - \\
FORSA Investment Company & U.A.E. & $100 \%$ \\
Istithmar World & U.A.E. & $100 \%$ \\
Jumeirah Golf Estates & U.A.E. & $100 \%$ \\
Leisurecorp & U.A.E. & $100 \%$ \\
Limitless World & U.A.E. & $100 \%$ \\
Nakheel Properties & U.A.E. & $100 \%$ \\
Pearl Valley Golf Estates & South Africa & $100 \%$ \\
Port and Free Zone World & U.A.E. & $100 \%$ \\
Thunder & U.A.E. & $100 \%$ \\
DP World & U.A.E. & $77 \%$ \\
CityCenter Holdings (Las Vegas) & United States & \\
Dubai Real Estate Institute & U.A.E. & \\
Imdaad & U.A.E. & \\
Infinity Holding World & U.A.E. & \\
Major Participations & & \\
MGM Mirage & United States & $9.40 \%$ \\
Deyaar Development Company & U.A.E. & $1.00 \%$ \\
GPS Industries & United States \\
Island Global Yachting & United States & \\
Snowmass Colorado & United States & \\
Troon Golf & United States & \\
Funds & & \\
DIB/DPW Family of Funds & Worldwide & \\
\hline
\end{tabular}

Sources: Zawya/Dow Jones, and Fund staff compilation.

18. The estimates of publicly-held debt are not comparable to the Fund's external debt concept, which is based on the residency principle, for two main reasons:

- $\quad$ Holders of debt that are resident, including U.A.E national banks (which hold 45 percent of the DW debt within the standstill perimeter) and foreign banks resident in the U.A.E., are excluded in the Fund's definition of external debt.

- Dubai Inc. owns businesses that are nonresident, and their debt should also be excluded. For example, outstanding international debt securities issued by U.A.E. residents amounted to $\$ 55$ billion in June 2009, but reached $\$ 74$ billion after adding the debt securities of nonresident issuers controlled by U.A.E. nationals, for example out of the Cayman Islands.

The information on publicly-held debt has the advantage of identifying a Dubai issuer, e.g., Dubai World or Nakheel, from any other U.A.E.-based issuer. Unfortunately, information on the assets of Dubai Inc.'s balance sheet is not available, except for a few listed entities, 
making it difficult to assess its net financial worth. ${ }^{2}$ As a point of comparison, the GREs of Abu Dhabi (excluding its SWFs) had assets of $\$ 61$ billion in 2008, and debts of $\$ 40$ billion as of November 2009.

\section{BIS statistics on international banking and debt securities are compiled on a} residency basis and can be used to build a rough estimate of the U.A.E.'s international investor position. Banks from 30 countries report most conventional claims, including bilateral loans; banks from a subset of 24 countries also report derivatives claims, guarantees and credit commitments. International debt securities are compiled by the BIS from market sources, and are reported by residency of issuer and nationality of issuer. Accounts' payables/suppliers' credit can be proxied by export credit exposures that are insured by OECD-based agencies. Staff has combined this data, together with estimates of external assets, including Abu Dhabi SWFs, to obtain a summary estimate of the IIP for the U.A.E. (Annex Table 2). Full details are provided in Annex Table 3.

\section{Central bank reserves, foreign assets of commercial banks, and deposits abroad} of non-banks are equivalent to twice the size of the external debt falling due in one year. Foreign assets of the banking system and nonbanks augmented by the external assets of SWFs and U.A.E. high net worth individuals (HNWIs) would cover the external debt twice over. The estimated IIP for 2009 is equivalent to 132 percent of GDP. This estimate is based on ADIA having foreign assets no larger than two times the size of Abu Dhabi's GDP. It implies that HNWIs, the SWEs of Abu Dhabi Inc., and Dubai Inc. would have external assets of only $\$ 20$ billion, a conservative estimate.

\footnotetext{
${ }^{2}$ For example, Emaar (property arm of ICD) disclosed consolidated assets of $\$ 18$ billion in 2009 in 60 companies (operations and investments) in 36 markets. It has full-fledged operations in the U.A.E., Saudi Arabia, Syria, Jordan, Lebanon, Egypt, Morocco, Algeria, Libya, India, Pakistan, Turkey, Indonesia, U.S.A., Canada, and UK.
} 
Annex Table 1. Dubai: Profile of Publicly-Held Debt in the Form of Bonds and Syndicated Loans 1/ 2/ (in millions of dollars or dollar equivalents)

\begin{tabular}{|c|c|c|c|c|c|c|c|c|c|}
\hline As of: January 2010 & Debt Type & 2010 & 2011 & 2012 & 2013 & 2014 & beyond & Total & Shares \\
\hline \multicolumn{10}{|l|}{ Dubai World (DW) and subsidiaries } \\
\hline \multirow[t]{3}{*}{ DW standstilled debt } & Bonds & 1,730 & 857 & 0 & 0 & 0 & 0 & 2,587 & \\
\hline & Syndicated loans & 3,439 & 3,790 & 1,850 & 1,050 & 350 & 1,284 & 11,763 & \\
\hline & Total & 5,169 & 4,647 & 1,850 & 1,050 & 350 & 1,284 & 14,350 & $17 \%$ \\
\hline \multicolumn{10}{|l|}{ Other DW subsidiaries (DP World, etc.) } \\
\hline & Bonds & 200 & 0 & 2,043 & 0 & 0 & 3,250 & 5,493 & \\
\hline & Syndicated loans & 0 & 2,000 & 3,700 & 500 & 0 & 0 & 6,200 & \\
\hline & Total other DW & 200 & 2,000 & 5,743 & 500 & 0 & 3,250 & 11,693 & $14 \%$ \\
\hline 1. Total Dubai World & & 5,369 & 6,647 & 7,593 & 1,550 & 350 & 4,534 & 26,043 & \\
\hline \multicolumn{10}{|l|}{ Dubai Holding \& subsidiaries } \\
\hline & Bonds & 0 & 221 & 500 & 104 & 1,016 & 722 & 2,563 & \\
\hline & Syndicated loans & 3,533 & 2,940 & 330 & 402 & 1,127 & 3,899 & 12,231 & \\
\hline 2. Total Dubai Holding & & 3,533 & 3,161 & 830 & 506 & 2,143 & 4,621 & 14,794 & $17 \%$ \\
\hline \multicolumn{10}{|l|}{ Inv. Corp. of Dubai \& subsidiaries (incl. banks) } \\
\hline & Bonds & 1,794 & 1,435 & 2,428 & 930 & 62 & 1,900 & 8,549 & \\
\hline & Syndicated loans & 170 & 4,375 & 3,281 & 2,080 & 93 & 1,856 & 11,855 & \\
\hline 3. Total ICD & & 1,964 & 5,810 & 5,709 & 3,010 & 155 & 3,756 & 20,404 & $24 \%$ \\
\hline \multicolumn{10}{|c|}{ Other Dubai Inc. (DEWA, PCFZ Corp., DIFC, etc.) } \\
\hline & Bonds & 400 & 0 & 1,250 & 1,471 & 0 & $2,2103 /$ & 5,331 & \\
\hline & Syndicated loans & 4,264 & 8,803 & 3,635 & 335 & 557 & 1,427 & 19,021 & \\
\hline 4. Total other Dubai Inc. & & 4,664 & 8,803 & 4,885 & 1,806 & 557 & 3,637 & 24,352 & $28 \%$ \\
\hline Total Dubai Inc. & & 15,530 & 24,421 & 19,017 & 6,872 & 3,205 & 16,548 & 85,592 & $100 \%$ \\
\hline Government of Dubai (GD) & & 0 & 0 & 0 & 1,770 & 21,930 & $04 /$ & 23,700 & \\
\hline Total Dubai Inc. and GD & & 15,530 & 24,421 & 19,017 & 8,642 & 25,135 & 16,548 & 109,293 & \\
\hline \multicolumn{10}{|l|}{ Memorandum items } \\
\hline Total, excluding Dubai Inc. banks 5/ & & 13,736 & 23,643 & 15,639 & 8,212 & 25,073 & 15,156 & 101,459 & 7,834 \\
\hline Government guaranteed 6/ & & 0 & 4,000 & 2,835 & 2,871 & 0 & 2,000 & 11,706 & \\
\hline Dubai-based private entities (partial data) & & 325 & 671 & 600 & 0 & 350 & 500 & 2,446 & \\
\hline
\end{tabular}

Sources: Dealogic, Zawya, Bloomberg, Dubai authorities, and Fund staff estimates and calculations.

1/ Excluding bilateral bank loans and accounts payable.

2/ Regardless of residency of debt holders.

3/ Assuming DEWA fully draws its receivables-securitization program under Thor Asset Purchase (Cayman) Ltd.

4/ Assuming Abu Dhabi direct and indirect support is fully drawn.

5/ Excluding local banks controlled by Dubai Inc.

6/ Mainly ICD holding level and DEWA/Thor.

Annex Table 2. U.A.E.: Summary Estimate of International Investment Position, 2004-09 $1 /$

\begin{tabular}{|c|c|c|c|c|c|c|}
\hline In billions of U.S. dollars (including local currency-denominated) & 2004 & 2005 & 2006 & 2007 & 2008 & 2009 \\
\hline $\begin{array}{l}\text { Maximum international debt, regardless of residency } 2 \text { / } \\
\text { In percent of GDP }\end{array}$ & $\begin{array}{r}45 \\
42 \%\end{array}$ & $\begin{array}{r}71 \\
53 \%\end{array}$ & $\begin{array}{r}121 \\
74 \%\end{array}$ & $\begin{array}{r}224 \\
108 \%\end{array}$ & $\begin{array}{r}236 \\
90 \%\end{array}$ & $\begin{array}{r}256 \\
111 \%\end{array}$ \\
\hline $\begin{array}{l}\text { External debt, adjusted for residency (A) } \\
\text { In percent of GDP }\end{array}$ & $\begin{array}{r}25 \\
23 \%\end{array}$ & $\begin{array}{r}37 \\
28 \%\end{array}$ & $\begin{array}{r}72 \\
44 \%\end{array}$ & $\begin{array}{r}121 \\
\mathbf{5 8 \%}\end{array}$ & $\begin{array}{r}135 \\
\mathbf{5 2} \%\end{array}$ & $\begin{array}{r}132 \\
57 \%\end{array}$ \\
\hline \multicolumn{7}{|l|}{ Memo, liabilities } \\
\hline External assets, excluding SWFs and HNWIs (B) & 78 & 97 & 128 & 172 & 116 & 114 \\
\hline Net assets, excluding SWFs and HNWIs (B-A) & 53 & 60 & 56 & 51 & -19 & -18 \\
\hline $\begin{array}{l}\text { Net assets, including SWF+HNWI } \\
\text { In percent of GDP }\end{array}$ & $\begin{array}{r}621 \\
582 \%\end{array}$ & $\begin{array}{r}522 \\
389 \%\end{array}$ & $\begin{array}{r}460 \\
281 \%\end{array}$ & $\begin{array}{r}410 \\
198 \%\end{array}$ & $\begin{array}{r}311 \\
119 \%\end{array}$ & $\begin{array}{r}305 \\
132 \%\end{array}$ \\
\hline $\begin{array}{l}\text { Memo, assets } \\
\text { Irrevocable loan facilities from global banks. }\end{array}$ & 9 & 22 & 20 & 37 & 37 & 35 \\
\hline
\end{tabular}

Sources: BIS; JEDH; authorities; and Fund staff estimates and calculations.

$1 /$ Orders of magnitude, estimated mainly from creditor data.

2/ Including insured export credit and off-balance sheet bank guarantees. 
Annex Table 3. U.A.E.: International Investment Position, Orders of Magnitude

\begin{tabular}{|c|c|c|c|c|c|c|}
\hline In billions of U.S. dollars (including local currency-denominated) & 2004 & 2005 & 2006 & 2007 & 2008 & 2009 \\
\hline \multicolumn{7}{|l|}{ Liabilities } \\
\hline International debt securities (by residency of issuer) & 3 & 8 & 30 & 43 & 46 & 55 \\
\hline Held by residents $1 /$ & 2 & 5 & 19 & 26 & 29 & 34 \\
\hline Non-resident holdings (A) & 1 & 3 & 12 & 16 & 18 & 21 \\
\hline Memo: by nationality of issuer $(B)$ & 3 & 9 & 32 & 52 & 60 & 74 \\
\hline financial institutions & 2 & 6 & 26 & 41 & 42 & 47 \\
\hline corporate issuers & 1 & 3 & 5 & 11 & 14 & 18 \\
\hline governments & 0 & 0 & 1 & 1 & 3 & 9 \\
\hline Cross-border bank debt $(\mathrm{C})$ & 23 & 33 & 58 & 98 & 106 & 102 \\
\hline UAE banks (incl. local offices of global banks) & 11 & 16 & 26 & 55 & 48 & 44 \\
\hline Nonbanks & 11 & 17 & 32 & 42 & 59 & 58 \\
\hline Memo: consolidated, excl. inter-office claims (D) & 32 & 45 & 67 & 121 & 121 & 130 \\
\hline International claims & 21 & 32 & 52 & 84 & 86 & 96 \\
\hline debt of UAE national banks & 8 & 9 & 14 & 28 & 24 & 23 \\
\hline debt of public sector & 1 & 4 & 3 & 5 & 8 & 9 \\
\hline debt of nonbank private sector & 11 & 19 & 35 & 50 & 54 & 65 \\
\hline Other (e.g., equity) & 0 & 0 & 1 & 2 & 2 & 2 \\
\hline Local claims in LC & 11 & 13 & 14 & 36 & 32 & 32 \\
\hline Other liabilities, excl. uninsured suppliers' credit (E) & 10 & 17 & 22 & 51 & 56 & 52 \\
\hline Insured export credit & 4 & 6 & 11 & 19 & 26 & 23 \\
\hline Derivatives $(F)$ & 1 & 2 & 2 & 7 & 12 & 9 \\
\hline Guarantees extended by global banks & 5 & 9 & 8 & 24 & 18 & 20 \\
\hline International debt, consolidated, incl. contingent $(B+D+E)$ & 45 & 71 & 121 & 224 & 236 & 256 \\
\hline In percent of GDP & $42 \%$ & $53 \%$ & $74 \%$ & $108 \%$ & $90 \%$ & $111 \%$ \\
\hline Idem, excl. contingent liabilities & 36 & 55 & 101 & 181 & 192 & 213 \\
\hline In percent of GDP & $33 \%$ & $41 \%$ & $62 \%$ & $87 \%$ & $73 \%$ & $92 \%$ \\
\hline External debt $(A+C+F)(G)$ & 25 & 37 & 72 & 121 & 135 & 132 \\
\hline In percent of GDP & $23 \%$ & $28 \%$ & $44 \%$ & $58 \%$ & $52 \%$ & $57 \%$ \\
\hline \multicolumn{7}{|l|}{ Memo } \\
\hline Debt falling due in one year & 16 & 20 & 32 & 53 & 53 & 57 \\
\hline International debt securities & 1 & 1 & 5 & 9 & 9 & 11 \\
\hline Bank debt & 15 & 20 & 28 & 44 & 43 & 46 \\
\hline \multicolumn{7}{|l|}{ Foreign assets, excluding SWFs and HNWIs $(\mathrm{H})$} \\
\hline Commercial banks & 34 & 48 & 63 & 54 & 55 & 56 \\
\hline Central bank & 19 & 21 & 28 & 78 & 31 & 28 \\
\hline Deposits of non-banks abroad & 25 & 28 & 37 & 41 & 30 & 31 \\
\hline Total & 78 & 97 & 128 & 172 & 116 & 114 \\
\hline Net assets, excluding SWFs and HNWIs (H-G) & 53 & 60 & 56 & 51 & -19 & -18 \\
\hline Foreign assets of SWFs+HNWIs (I) $2 /$ & 568 & 462 & 404 & 359 & 330 & 323 \\
\hline Net assets, including SWF+HNWI (I-G) & 621 & 522 & 460 & 410 & 311 & 305 \\
\hline In percent of GDP & $582 \%$ & $389 \%$ & $281 \%$ & $198 \%$ & $119 \%$ & $132 \%$ \\
\hline \multicolumn{7}{|l|}{ Memo asset } \\
\hline Credit commitments $3 /$ & 9 & 22 & 20 & 37 & 37 & 35 \\
\hline
\end{tabular}

Sources: BIS; JEDH; authorities; and Fund staff estimates and calculations.

$1 / 38 \%$ of international debt securities was held by nonresidents in 2006 , latest such data available.

2/ Assuming foreign assets of $\$ 300$ billion in 2008 for all UAE SWFs and sovereign wealth enterprises, plus $10 \%$ for HNWI.

3 / Irrevocable loan facilities from global banks. 


\section{INTERNATIONAL MONETARY FUND \\ UNITED ARAB EMIRATES \\ 2009 Article IV Consultation \\ Informational Annex}

Prepared by the Middle East and Central Asia Department

January 21, 2010

Contents

Page

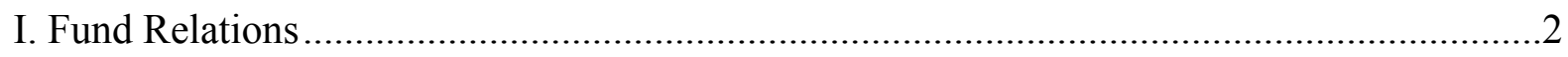

II. Relations with the World Bank Group.................................................................

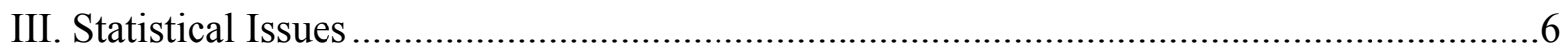




\section{APPENDIX I: UNITED ARAB EMIRATES-FUND RELATIONS}

(As of December 31, 2009)

I. Membership Status: Joined 9/22/72; accepted Article VIII status in February 1974.

II. General Resources Account:

$\begin{array}{cc}\text { SDR Million } & \text { Percent of Quota } \\ 611.70 & 100.00 \\ 493.86 & 80.74 \\ 118.42 & 19.36\end{array}$

III. SDR Department:

$\begin{array}{cc}\text { SDR Million } & \text { Percent of Allocation } \\ 568.41 & 100.00 \\ 541.03 & 95.18\end{array}$

Holdings

IV. Outstanding Purchases and Loans: None

V. Financial Arrangements: None

VI. Projected Payments to Fund:

(SDR million; based on existing use of resources and present holdings of SDRs):

\begin{tabular}{lccccc}
\hline & \multicolumn{5}{c}{ Forthcoming } \\
& 2010 & 2011 & 2012 & 2013 & 2014 \\
\hline $\begin{array}{l}\text { Principal charges/ } \\
\quad \text { Interest }\end{array}$ & & & & & \\
Total & 0.11 & 0.11 & 0.11 & 0.11 & 0.11 \\
\hline
\end{tabular}

VII. Implementation of HIPC Initiative: Not Applicable

VII. Implementation of Multilateral Debt Relief Initiative (MDRI): Not Applicable

\section{Exchange Rate Arrangement:}

The U.A.E. dirham was officially pegged to the SDR at the rate of AED $4.76190=$ SDR 1 from November 1980 to February 2002 - albeit de facto it was pegged to the dollar at a fixed parity. Since then, the U.A.E. dirham has been de jure pegged to the U.S. dollar. The midpoint between the official buying and selling rates for the dirham has been AED 3.6725 = \$1 since November 1997. 


\section{Exchange System}

The U.A.E.'s exchange system is free of restrictions on the making of payments and transfer for current international transactions, except for those restrictions that are yet to be notified to the Fund, by the authorities, in accordance with Executive Board Decision No. 144 (52/51).

\section{Article IV Consultation}

The U.A.E. is on the annual consultation cycle. The previous consultation discussions were held during October 20-November 2, 2008. The staff report (SM/08/342) and the Statistical Appendix (SM/08/343) were discussed by the Executive Board on January 9, 2009.

\section{FSAP Participation, ROSCs, and OFC Assessments}

FSAP missions visited U.A.E. in 2003 and 2007.

\section{Technical Assistance:}

\begin{tabular}{|c|c|c|}
\hline STA & Multi-sector & June 1993 \\
\hline FAD & Government financial management & June 1994 \\
\hline STA & Data collection and balance of payments & December 1995 \\
\hline STA & $\begin{array}{l}\text { Terms of reference and arrangements for } \\
\text { resident advisor in balance of payments }\end{array}$ & April 1997 \\
\hline STA & International reserves & May 1998 \\
\hline FAD & Public Expenditure Management & November 2000 \\
\hline FAD & Public Expenditure Management follow up & May 2003 \\
\hline STA & Multi-sector & December 2003 \\
\hline MFD & $\begin{array}{l}\text { Anti-Money Laundering/Combating } \\
\text { terrorist financing }\end{array}$ & March 2004 \\
\hline STA & Coordinated Portfolio Investment Survey & April 2004 \\
\hline FAD & $\begin{array}{l}\text { Revenue Diversification and VAT } \\
\text { Feasibility }\end{array}$ & November 2005 \\
\hline FAD & Public Financial Management & November 2005 \\
\hline FAD & $\begin{array}{l}\text { Gulf Cooperation Council: Options for } \\
\text { Indirect Taxation }\end{array}$ & March 2006 \\
\hline FAD & $\begin{array}{l}\text { U.A.E.: Options for New Indirect Taxation } \\
\text { and Intergovernmental Fiscal Relations }\end{array}$ & March 2006 \\
\hline STA & Compilation of a high-frequency CPI Index & March 2007 \\
\hline STA & Multi-sector & April 2008 \\
\hline STA & Balance of Payments & March-April 2009 \\
\hline
\end{tabular}

\section{Resident Representative: None.}




\section{APPENDIX II: UNITED ARAB EMIRATES-RELATIONS WITH THE WORLD BANK GROUP}

As of January 17, 2010

\section{The World Bank}

During 2008-09, the World Bank assisted the Ministry of Finance in building the capacity to issue treasury bonds. Phases one (the assessment report) and two (legislation and market infrastructure report) are completed. Components include assistance in drafting of the debt framework law (since enacted) and the operational guidelines for the Debt Management Office (DMO) of the U.A.E., as well as providing a sample code of conduct for the DMO. Phase 3, as envisaged, will involve support to the operation of the DMO.

As part of ongoing consultations on a regional financial sector report to be published in 2010, Bank staff have held discussions with the Ministry of Finance and Central Bank concerning options for strengthening the functioning of the U.A.E. financial sector.

Within the U.A.E., the Bank has been cooperating with individual Emirates on an ad hoc basis.

- In Ras Al Khaimah (RAK), technical cooperation has included

- Promoting a better investment climate and assisting in mobilizing private investment: an investors' conference (May 2005) attracted major strategic, financial and individual investors from around the world and had a significant impact on the investment climate improvement;

- More recently, the Government of RAK requested the World Bank's technical assistance to design a multi-jurisdictional student loan program. Under the program, financial aid will be provided to students enrolled in courses at the International Trade and Hospitality Program (a joint venture partnership between the Government of RAK and the International Development Corporation (IDC) providing an education, training and job placement system designed to meet the needs of future and current employees and managers of the hospitality industry).

- In Abu Dhabi, the Bank is providing assistance to

- Abu Dhabi Food Control Authority, which is currently developing and implementing a food security program for the emirate of Abu Dhabi with the potential for developing a U.A.E.-wide approach; and

- Abu Dhabi Judicial Department, which is undertaking a judicial reform.

- In Dubai, the Bank has provided background information about public sector reform strategies to the Executive Council. 


\section{International Finance Corporation (IFC)}

IFC continues to provide ad hoc support to the U.A.E. at the federal and local levels through its regional office in Dubai. In addition, IFC's Doing Business team has been working with the Emirates Competitiveness Council (a joint federal and emirate body) to address constraints identified in IFC's ease of doing business global rankings.

\section{Multilateral Investment Guarantee Agency (MIGA)}

MIGA has provided political risk insurance for a container terminal project in Djibouti to be run under a 30 year concession by Dubai Ports World. The $\$ 427$ million guarantee was specially designed to accommodate the Islamic financing structure for the project. 


\section{APPENDIX III: UNITED ARAB EMIRATES-STATISTICAL ISSUES}

\begin{tabular}{|c|}
\hline $\begin{array}{c}\text { U.A.E.-STATISTICAL ISSUES APPENDIX } \\
\text { As of January } 19,2010\end{array}$ \\
\hline Assessment of Data Adequacy for Surveillance \\
\hline $\begin{array}{l}\text { General: Data provision is broadly adequate for surveillance. The federal and individual emirates' } \\
\text { agencies have improved the availability and quality of the statistics, although much needs to be done. } \\
\text { The adoption of the Federal Statistics Law on May 18, 2009, and the establishment of an independent } \\
\text { National Bureau of Statistics (NBS) are important steps in establishing a statistical system at the } \\
\text { federal level. While the Law expressly requires all agencies and local statistical centers to provide } \\
\text { data as required by the NBS, progress in compiling accurate and timely data will depend on the } \\
\text { issuance of implementation regulations (including the delineation of responsibilities among agencies } \\
\text { that compile statistics), staffing, funding and training, as well as political commitment. }\end{array}$ \\
\hline $\begin{array}{l}\text { National Accounts: The methodology broadly conforms to the } 1968 \text { SNA. GDP is compiled } \\
\text { annually with a lag of around } 18 \text { months and only current price expenditure estimates are available. } \\
\text { Some progress has been made in improving the source data but further work is needed to improve } \\
\text { updating procedures, and quarterly indicators are not available. }\end{array}$ \\
\hline $\begin{array}{l}\text { Price statistics: Following technical assistance from the IMF Statistics Department, the Ministry of } \\
\text { Economy started publishing a monthly CPI since January 2008. However, price indexes and GDP } \\
\text { deflators need further harmonization at the federal level. }\end{array}$ \\
\hline $\begin{array}{l}\text { Government finance statistics: In 2008, six of the seven emirates and the federal government have } \\
\text { received technical support in the compilation of fiscal data on a consolidated basis, using the GFSM } \\
2001 \text { format and } 2008 \text { as a base year. The authorities, however, are yet to adopt the action plan to } \\
\text { establish a fiscal reporting system for the production of the GFS in a regular and timely manner. An } \\
\text { institutional arrangement will need to be established to ensure adequate data provision. This } \\
\text { consolidation should complement initiatives to establish Debt Management Units at both the emirate } \\
\text { and federal levels. }\end{array}$ \\
\hline $\begin{array}{l}\text { Monetary statistics: The central bank has recently shifted the responsibility for compiling and } \\
\text { disseminating monetary data to the Banking Supervision and Examination Department, in order to } \\
\text { improve the timeliness of data to monthly frequency with less than a month lag. Although some } \\
\text { monthly aggregates and FSIs are already published on a monthly basis the Banking Supervision and } \\
\text { Examination Department has not been trained in MFSM } 2000 \text { and the published data do not follow } \\
\text { the recommended methodology. }\end{array}$ \\
\hline $\begin{array}{l}\text { Balance of Payments: The information needed to compile the balance of payments is insufficient, } \\
\text { especially for the financial account. Many components of the IIP also are missing or incomplete, as } \\
\text { the data on government foreign assets and private holdings of foreign assets and liabilities are not } \\
\text { published or lack appropriate surveys. The development of a comprehensive Balance of Payments } \\
\text { and IIP is however within the reach of the U.A.E. if the Central Bank, the NBS, and the Ministry of } \\
\text { Economy strengthen their capacity and receive appropriate support at the high level. The authorities } \\
\text { have indicated their interest in IMF technical assistance. }\end{array}$ \\
\hline
\end{tabular}




\section{Data Standards and Quality}

Participant in the GDDS since July 31, 2008. Data Module of the ROSC: none

The metadata were last updated in 2008

(Monetary and BOP), 2008 (National Accounts and Prices), and 2008 (Government Finance). 
UNITED ARAB EMIRATES: TABLE OF COMMON INDICATORS REQUIRED FOR SURVEILLANCE

(As of January 19, 2010)

\begin{tabular}{|c|c|c|c|c|c|}
\hline & $\begin{array}{c}\text { Date of } \\
\text { latest } \\
\text { observation }\end{array}$ & $\begin{array}{l}\text { Date } \\
\text { received }\end{array}$ & $\begin{array}{c}\text { Frequency } \\
\text { of } \\
\text { Data }^{6}\end{array}$ & $\begin{array}{l}\text { Frequency } \\
\text { of } \\
\text { Reporting }^{8}\end{array}$ & $\begin{array}{l}\text { Frequency } \\
\text { of } \\
\text { publication }^{8}\end{array}$ \\
\hline Exchange Rates & Real time & Real time & $\mathrm{D}$ & M & M \\
\hline $\begin{array}{l}\text { International Reserve Assets and } \\
\text { Reserve Liabilities of the Monetary } \\
\text { Authorities }^{1}\end{array}$ & $11 / 09$ & $1 / 10$ & M & M & M \\
\hline Reserve/Base Money & $11 / 09$ & $1 / 10$ & M & M & M \\
\hline Broad Money & $11 / 09$ & $1 / 10$ & M & M & M \\
\hline Central Bank Balance Sheet & $11 / 09$ & $1 / 10$ & M & M & M \\
\hline $\begin{array}{l}\text { Consolidated Balance Sheet of the } \\
\text { Banking System }\end{array}$ & $11 / 09$ & $1 / 10$ & M & M & M \\
\hline Interest Rates ${ }^{2}$ & Real time & Real time & $\mathrm{D}$ & $\mathrm{D}$ & $\mathrm{D}$ \\
\hline Consumer Price Index & $11 / 09$ & $1 / 10$ & M & M & M \\
\hline $\begin{array}{l}\text { Revenue, Expenditure, Balance and } \\
\text { Composition of Financing }{ }^{3}-\text { General } \\
\text { Government }^{4}\end{array}$ & 2008 & $1 / 10$ & A & A & $\mathrm{A}$ \\
\hline $\begin{array}{l}\text { Revenue, Expenditure, Balance and } \\
\text { Composition of Financing }{ }^{3}-\text { Central } \\
\text { Government }\end{array}$ & 2008 & $1 / 10$ & A & A & $\mathrm{A}$ \\
\hline $\begin{array}{l}\text { Stocks of Central Government and } \\
\text { Central Government-Guaranteed Debt }\end{array}$ & 2008 & $1 / 10$ & A & A & A \\
\hline External Current Account Balance & 2008 & $1 / 10$ & A & A & A \\
\hline $\begin{array}{l}\text { Exports and Imports of Goods and } \\
\text { Services }\end{array}$ & 2008 & $1 / 10$ & A & A & A \\
\hline GDP/GNP & 2008 & $1 / 10$ & A & A & A \\
\hline Gross External Debt & $\ldots$ & $\ldots$ & NA & NA & NA \\
\hline International Investment Position ${ }^{7}$ & $\ldots$ & $\ldots$ & NA & NA & NA \\
\hline
\end{tabular}

${ }^{1}$ Include reserve assets pledged or otherwise encumbered as well as net derivative positions.

${ }^{2}$ Both market-based and officially determined, including discount rates, money market rates, rates on treasury bills, notes and bonds.

${ }^{3}$ Foreign, domestic bank, and domestic nonbank financing.

${ }^{4}$ The general government consists of the central government (budgetary funds, extra budgetary funds, and social security funds) and state and local governments.

${ }^{5}$ Federal government only.

${ }^{6}$ Including currency and maturity composition.

${ }^{7}$ Includes external gross financial asset and liability positions vis-à-vis nonresidents.

${ }^{8}$ Daily (D), Weekly (W), Monthly (M), Quarterly (Q), Annually (A), Irregular (I); Not Available (NA). 


\section{IMF Executive Board Concludes 2009 Article IV Consultation with United Arab Emirates}

On February 3, 2010, the Executive Board of the International Monetary Fund (IMF) concluded the Article IV consultation with United Arab Emirates. ${ }^{1}$

\section{Background}

The United Arab Emirates (U.A.E.) was adversely affected by a series of external and domestic shocks in 2009, including the global economic slowdown, the shutdown of international capital markets, and the impact of the bursting Dubai property bubble in mid-2008. Oil receipts plummeted, global trade and logistics contracted, as did property/construction activities.

A second bout of disruption arose when Dubai World (DW) announced in late November 2009 that it would seek a debt standstill through May 2010, including on bonded debt owed by its Nakheel property subsidiary. Market tensions calmed down after DW paid off the Nakheel bond on time in December with financial support from Abu Dhabi, but uncertainties remain. In particular, discussions on the modalities of Dubai's debt restructuring are still ongoing, access to financial markets by Dubai entities has become more difficult, and it will take some time for the Government of Dubai (GD) to design and implement a strategy on the operational restructuring of its government-related entities (GREs).

\footnotetext{
${ }^{1}$ Under Article IV of the IMF's Articles of Agreement, the IMF holds bilateral discussions with members, usually every year. A staff team visits the country, collects economic and financial information, and discusses with officials the country's economic developments and policies. On return to headquarters, the staff prepares a report, which forms the basis for discussion by the Executive Board. At the conclusion of the discussion, the Managing Director, as Chairman of the Board, summarizes the views of Executive Directors, and this summary is transmitted to the country's authorities. An explanation of any qualifiers used in summings up can be found here: http://www.imf.org/external/np/sec/misc/qualifiers.htm.
} 
Overall real GDP is estimated to have contracted by about $1 / 2$ percent in 2009 . Hydrocarbon GDP declined by $61 / 4$ percent, while nonhydrocarbon growth, which had averaged 8 percent in the three previous years, is estimated to have slowed to about 1 percent. This figure masks the diverging fortunes of Abu Dhabi (where growth was sustained by public sector investment spending) and the northern emirates (in particular Dubai and Sharjah), where economic activity dropped owing to the bursting property bubble and the contraction in world trade.

After peaking at about 12 percent in 2008, annual consumer inflation declined to about 1 percent in 2009, reflecting lower import prices and a reduction in rents arising from an increased supply of buildings as well as the renewal of contracts at deflated market prices.

The external current account balance is estimated to have shifted to a deficit of 2.7 percent of GDP in 2009, the first deficit in decades. As a result of OPEC-mandated production cuts and lower prices, hydrocarbon export revenues dropped by about 45 percent in 2009 , while imports fell by 22 percent owing to a sharp contraction in consumer goods imports and despite the large public infrastructure projects in Abu Dhabi. The reopening of capital markets in the second quarter of 2009 and external borrowing particularly by Abu Dhabi entities helped stabilize the international reserves position by the end of 2009 .

The consolidated fiscal position is estimated at a virtual balance in 2009 , following a surplus of 21 percent of GDP in 2008. Both oil and non-oil revenues fell owing to the decline in oil prices and the slowdown in economic activity, while spending increased by about 14 percent-a continuation of the expansionary fiscal stance adopted in 2008. The nonhydrocarbon deficit widened by about 7 percentage points to 34 percent of non-oil GDP in 2009, owing mainly to higher outlays by Abu Dhabi on strategic projects.

Broad money growth slowed from 19 percent in 2008 to 10 percent in 2009. Real credit to the private sector was flat in 2009 as demand weakened and commercial banks adopted a much more cautious approach in response to the riskier conditions. Credit was redirected towards public sector enterprises, and banks increased their holding of central bank CDs.

As the global crisis intensified, the authorities implemented measures to maintain confidence in the banking system, including recapitalization. As a result, the capital adequacy ratio of national banks increased from 13 percent to 18 percent in half a year. The authorities are currently working on tightening the regulatory framework by introducing a general provision for unclassified loans, standardizing loan classification, and enforcing provisioning standards uniformly.

\section{Executive Board Assessment}

Executive Directors commended the U.A.E. authorities for their decisive response to shocks from the global financial crisis, lower oil prices, and the bursting of the Dubai bubble. Directors noted, however, that these shocks, together with the recent announcement that DW would seek a six-month debt standstill, have raised important challenges for the U.A.E. economy. 
Directors agreed that the prospects for the U.A.E. economy, given its underlying strengths, remain favorable. It will be important, however, to embark on a more balanced and sustainable growth path over the medium term.

Directors welcomed the ongoing engagement with DW's creditors and stressed the importance of a speedy, orderly, cooperative, and predictable approach to debt restructuring. They underscored that the process should seek to enhance transparency and information disclosure and ensure comparability of treatment among creditors. They also emphasized that debt restructuring should be accompanied by a vigorous effort to undertake an operational restructuring of GREs, including formulating exit strategies for nonviable corporations, a process that will likely take time.

Directors welcomed the steps taken by the authorities to strengthen confidence in the banking system, but noted that the DW event had highlighted the need for additional contingency planning measures. In this context, Directors stressed the need to articulate a plan for dealing with the potential increase in loan losses. They also emphasized the importance of pressing ahead with introducing general loan provisions, enforcing more uniform provisioning and loan classification standards, and further strengthening capital buffers. Directors agreed that macroprudential policies should play an increasingly important role over the medium term, and noted that countercyclical solvency and liquidity measures, as well as closer monitoring of systemically important banks, could complement other regulatory policies. Directors also recommended an assessment of corporate governance, as well as development of a federal insolvency law.

Directors welcomed recent initiatives aimed at improving policy coordination at the federal level, including the establishment of a Fiscal Coordination Committee, the development of multi-year expenditure plans, and the introduction of debt management units. Looking ahead, they encouraged the authorities to rationalize investment decisions at the federal level, and to respond flexibly to the uncertainties surrounding the global outlook. Directors underscored that, given the limitations of monetary policy, fiscal policy should continue to play an important role in supporting economic activity. Most Directors agreed that the exchange rate peg to the U.S. dollar has provided a credible anchor and contributed to macroeconomic stability.

Directors stressed the need for increased transparency of economic and financial data, including financial accounts and business strategies for GREs. Together with improved corporate governance, Directors concluded that these steps would contribute to facilitating access of viable GREs to capital markets.

Directors viewed the adoption of the Federal Statistics Law and the establishment of the National Bureau of Statistics as important steps toward developing capacity at the federal level. They stressed the need to develop an action plan including the issuance of implementing regulations and a strengthening of the Board's operational independence. Directors also welcomed the authorities' efforts to compile consolidated fiscal statistics and encouraged them to pursue plans to develop leading indicators and the U.A.E's international investment position, in line with initiatives under the General Data Dissemination System. 
Public Information Notices (PINs) form part of the IMF's efforts to promote transparency of the IMF's views and analysis of economic developments and policies. With the consent of the country (or countries) concerned, PINs are issued after Executive Board discussions of Article IV consultations with member countries, of its surveillance of developments at the regional level, of post-program monitoring, and of ex post assessments of member countries with longer-term program engagements. PINs are also issued after Executive Board discussions of general policy matters, unless otherwise decided by the Executive Board in a particular case. 
United Arab Emirates: Selected Macroeconomic Indicators, 2005-10 1/

\begin{tabular}{|c|c|c|c|c|c|c|}
\hline & 2005 & 2006 & 2007 & 2008 & $\begin{array}{l}\text { Est. } \\
2009\end{array}$ & $\begin{array}{l}\text { Proj. } \\
2010\end{array}$ \\
\hline & \multicolumn{6}{|c|}{ (Annual percent change, unless otherwise indicated) } \\
\hline \multicolumn{7}{|l|}{ Output and prices } \\
\hline Nominal GDP (in billions of AED) & 492.7 & 601.3 & 762.3 & 959.8 & 845.6 & 909.6 \\
\hline Nominal GDP (in billions of U.S. dollars) & 134.2 & 163.7 & 207.6 & 261.4 & 230.3 & 247.7 \\
\hline Real GDP (at factor cost) & 8.2 & 8.7 & 6.1 & 5.1 & -0.7 & 0.6 \\
\hline Real oil and gas GDP & 1.6 & 6.5 & -2.7 & 1.6 & -6.3 & 2.7 \\
\hline Real non-oil GDP & 10.8 & 9.5 & 9.1 & 6.3 & 1.0 & 0.0 \\
\hline CPI inflation (average) & 6.2 & 9.3 & 11.6 & 11.5 & 1.0 & 1.5 \\
\hline & \multicolumn{6}{|c|}{ (In percent of GDP, unless otherwise indicated) } \\
\hline \multicolumn{7}{|l|}{ Public finances } \\
\hline Revenue & 41.4 & 49.7 & 43.4 & 46.9 & 34.6 & 39.7 \\
\hline Hydrocarbon & 31.0 & 38.2 & 30.9 & 37.7 & 25.7 & 30.9 \\
\hline Nonhydrocarbon & 10.3 & 11.6 & 12.5 & 9.2 & 8.9 & 8.8 \\
\hline Expenditure and net lending & 21.2 & 21.2 & 21.9 & 26.4 & 34.2 & 29.8 \\
\hline Budget balance & 20.2 & 28.5 & 21.5 & 20.5 & 0.4 & 9.8 \\
\hline Nonhydrocarbon balance 2/ & -16.5 & -13.7 & -14.2 & -27.1 & -33.7 & -29.7 \\
\hline & \multicolumn{6}{|c|}{ (Annual percent change) } \\
\hline \multicolumn{7}{|l|}{ Monetary sector } \\
\hline Credit to private sector & 44.5 & 36.9 & 40.1 & 49.3 & 1.9 & 0.5 \\
\hline Broad money & 33.8 & 23.2 & 41.7 & 19.2 & 9.7 & 6.3 \\
\hline & \multicolumn{6}{|c|}{ (In billions of U.S. dollars, unless otherwise indicated) } \\
\hline \multicolumn{7}{|l|}{ External sector } \\
\hline Exports of goods & 115.4 & 144.6 & 179.1 & 239.8 & 163.0 & 182.3 \\
\hline Oil and gas & 53.2 & 69.1 & 74.3 & 102.7 & 56.8 & 71.8 \\
\hline Imports of goods & -74.5 & -88.1 & -132.1 & -176.3 & -137.2 & -135.1 \\
\hline Current account balance & 22.7 & 36.2 & 19.5 & 22.2 & -6.2 & 18.1 \\
\hline Current account balance (in percent of GDP) & 16.9 & 22.1 & 9.4 & 8.5 & -2.7 & 7.3 \\
\hline Gross official reserves & 21.3 & 28.0 & 77.9 & 30.9 & 29.9 & 39.5 \\
\hline In months of next year imports of goods and services & 2.3 & 2.0 & 4.3 & 2.2 & 2.1 & 2.4 \\
\hline Real effective exchange rate $(2000=100)$ & 96.0 & 101.2 & 103.6 & 107.5 & 121.5 & $\ldots$ \\
\hline
\end{tabular}

Sources: U.A.E. authorities; and IMF staff estimates.

1/ Projections are based on information received through November 2009.

2/ In percent of nonhydrocarbon GDP. 


\section{Statement by A. Shakour Shaalan, Executive Director \\ for the United Arab Emirates \\ February 3, 2010}

\section{Overview}

1. Following several years of rapid growth and structural reforms, the United Arab Emirates (U.A.E.) economy was adversely affected by the global economic financial crisis, the sharp drop in oil prices, and the correction of the Dubai property market. These events were cushioned by the prudent management of the economy during the previous years, which resulted in strong fiscal and current account surpluses, and sizeable net foreign assets. With this solid position, the authorities took decisive measures to mitigate the impact of these shocks on the economy. The recent announcement by Dubai World (DW) that it will seek a standstill and restructuring of debt had only limited spillover effects given the solid creditworthiness of the U.A.E.

\section{Developments since the last Article IV Consultation}

2. The U.A.E.'s economy showed signs of slowdown in the second half of 2008 . It experienced a mild contraction in 2009, reflecting a decline in oil output - in line with OPEC-agreed production cuts - and lower non-oil growth associated with the property market correction and tight credit conditions. Non-hydrocarbon GDP growth dropped from an average of 8 percent during 2006-2008 to 1 percent in 2009. Hydrocarbon exports plunged by about 45 percent, leading to the emergence of a current account deficit of GDP. Inflation fell substantially from a peak of 12 percent in 2008 to around 1 percent in 2009, mainly reflecting a reduction in rents and import prices. Of course, in this environment bank credit dropped sharply.

3. The authorities acted swiftly to preserve financial stability, mitigate the impact of spillovers, and support economic activity in 2009. The fiscal stance continued to be expansionary, and focused on capital spending on infrastructure as well as on lending to public corporations. Public expenditures increased sharply, which together with the decline in revenues, resulted in the deterioration of the consolidated fiscal position from a surplus of 21 percent of GDP in 2008 to balance in 2009. The Central Bank of the U.A.E. pursued policies to shore up confidence in the financial sector and provide needed liquidity. It lowered the repurchase rate in early 2009 , in tandem with cuts by the U.S. Federal Reserve, and created a sizeable concessional short-term lending facility.

4. The authorities also stepped in to bolster bank capitalization. With capital injections from the federal and Emirates' governments, the U.A.E. average bank capital adequacy ratio shifted from the lowest ratio among GCC countries prior to the crisis to the highest ratio. The very stringent stress tests conducted by the staff confirm that bank capitalization is broadly adequate to withstand severe shocks. 
5. The announcement of the DW debt standstill led to a strong but brief market reaction, mainly because the assumption of an implicit sovereign guarantee was shaken. The authorities consider that the market reaction created exaggerated uncertainty. CDS spreads rose temporarily and there has been virtually no impact on cross border flows within the banking system. The authorities decided to fully repay the US\$3.5 billion sukuks maturing on December 14 - even though these were not guaranteed by the sovereign - in order to allow time to coordinate with creditors on the remainder of the US\$26 billion.

\section{Outlook and policies in 2010}

6. Growth is expected to start recovering in 2010. The authorities forecast that GDP growth will likely be higher than the staff estimate. They do not expect a deceleration in nonoil GDP in 2010, as Abu Dhabi's oil and non-oil sectors are set to expand, and improved global conditions will help Dubai's services to reemerge. Some degree of uncertainty will remain with respect to the pace of recovery of Dubai's real estate sector. These prospects will be underpinned by continued federal support. The federal government will maintain its development expenditures, as well as the provision of loans and equity support for viable Government Related Entities (GRE). To help preserve financial stability, the central bank will stand ready to sterilize renewed inflows by raising reserve requirements in the event of overheating, and to inject liquidity as needed in the event credit conditions tighten. Given the limited scope for monetary policy, macroprudential policies will play an important role in the case of renewed pressures from inflows. The authorities reaffirm their commitment to the dollar peg, which has served the economy well and provided a stable anchor in the face of uncertainty.

\section{Steps to safeguard financial stability}

7. The crisis revealed some financial sector vulnerabilities, namely the overleveraging - which was facilitated by lax global liquidity conditions in 2004-2007-and the maturity mismatch. In addition to the increase in bank capitalization, the authorities are considering steps to further strengthen cross-firm supervision and macroprudential policies, including counter-cyclical solvency and liquidity measures. These measures include direct limits on GRE borrowing, standardizing and strengthening loan classification and provisioning rules, and stricter enforcement. Some banks have already been requested to immediately increase provisioning. To secure longer-term financing for up-scaled investment and mega-projects, the authorities are drafting laws and regulations to foster a local debt market and to extend the average debt maturity.

8. The authorities are setting the scope and modalities for restructuring the remaining US\$22 billion debt in a fair and equitable manner, and launched an insolvency law reform to facilitate the debt restructuring and preserve the rights of DW creditors. They also recently established a US\$20 billion Dubai Support Fund, which will be directed at supporting viable and strategic public entities with the assistance of a chief restructuring officer. To the extent possible, the authorities intend to avoid the sale of assets and to focus on securing longerterm refinancing for viable projects. While the authorities will continue to selectively support viable entities to ensure that contagion is contained, they intend to minimize the bailout of commercial entities that are not guaranteed in order to avoid moral hazard and burdening the 
sovereign's balance sheet, in line with the best practices which are described in Box 2 of the staff report.

\section{Transparency and statistics}

9. The government of Dubai has underscored its "strong commitment, as a global financial leader, to transparency, good governance, and market principles ${ }^{1}$. With respect to the concerns that were raised regarding the lack of public information, I would note that the creditor banks - which hold the bulk of outstanding US\$22 billion debt - had access to the financial statements of Dubai Inc. entities. Moreover, the absence of government guarantees was clearly spelled out in the prospectus of the Nakheel 09 sukuk. It therefore appears that investors who assumed that the bonds were government-guaranteed either neglected to carefully read the prospectus or were counting on a sovereign bail-out. In this regard, "lack of information disclosure and transparency" cannot be viewed as the primary cause of market volatility, as suggested in paragraph 2 of the staff report.

10. The authorities are building a federal economic and statistical database. They adopted the federal statistics law and established an independent federal statistics bureau in 2009 in order to coordinate data collection, compilation, and dissemination. The authorities also plan to increase transparency in financial data, notably for government-related enterprises.

\section{Other reforms}

11. The U.A.E. will continue to gear its policies toward promoting further diversification of its productive base and government revenue. To this end, and with a view to foster longterm fiscal sustainability in the context of a growing non-hydrocarbon economy, consideration is being given to introducing a VAT within two years. The authorities are aiming to coordinate fiscal policy, strengthen budget procedures, and centralize debt management at the federal level, given that each of the seven emirates has autonomy with regards to its natural resources and fiscal policy. Under the auspices of the newly established Fiscal Coordination Committee, the U.A.E. will begin releasing its federal budget every three years, beginning in 2011-2013, with the aim of coordinating the fiscal stance between the emirates. In addition, debt management units are to be created to better coordinate financing needs between the emirates and federal government.

\section{Conclusion}

12. In conclusion, it is clear that the government of the U.A.E. is not only fully aware of the issues that need to be addressed but has or is in the process of introducing measures to prevent such a repeat. I am confident that the authorities will overcome the challenges they are currently facing and will continue to lay the foundations for sustainable growth in the Emirates.

\footnotetext{
${ }^{1}$ HH Sheikh Ahmad Bin Saeed Al Maktoum, Chairman of the Dubai Supreme Fiscal Committee, Dubai, December 14, 2009. www.centralbank.ae/press releases.php
} 